\title{
Portage: Path Dependence and Increasing Returns in U.S. History *
}

\author{
Hoyt Bleakley ${ }^{\dagger} \quad$ Jeffrey $\operatorname{Lin}^{\ddagger}$
}

August 25, 2010

\begin{abstract}
We examine portage sites in the U.S. South, Mid-Atlantic, and Midwest, including those on the fall line, a geomorphologic feature in the southeastern U.S. marking the final rapids on rivers before the ocean. Historically, waterborne transport of goods required portage around the falls at these points, while some falls provided water power during early industrialization. These factors attracted commerce and manufacturing. Although these original advantages have long since been made obsolete, we document the continuing - and even increasing-importance of these portage sites over time. We interpret this finding in a model with path dependence arising from local increasing returns to scale.
\end{abstract}

Keywords: economic geography, history dependence, initial conditions, fall line, coordination problem

${ }^{*}$ The authors thank Nate Baum-Snow, Henry Binford, Lou Cain, Satyajit Chatterjee, Tim Conley, Bob Fogel, Gordon Hanson, Dave Haddock, Kris Mitchener, Kevin Murphy, Jordan Rappaport, Steve Redding, and Mark Wright for helpful discussions, Cristine McCollum at the FRBP library for finding several sources of data, Lauris Olsen for help with the Serial Set at Penn, Chris Winters for patient guidance through the U of C map collection, Evan Taylor and Allison Kahl for research assistance, and seminar participants at various institutions for helpful comments. The views expressed here are those of the authors and do not necessarily represent the views of the Federal Reserve Bank of Philadelphia or the Federal Reserve System.

${ }^{\dagger}$ Associate Professor of Economics, Booth School of Business, University of Chicago. Postal address: 5807 South Woodlawn Avenue, Chicago, IL 60637. Electronic mail: bleakley at uchicago dot edu.

${ }^{\ddagger}$ Economist, Research Department, Federal Reserve Bank of Philadelphia. Postal address: Ten Independence Mall, Philadelphia, PA 19106. Electronic mail: jeff dot lin at phil dot frb dot org. 


\section{Introduction}

Why is economic activity distributed unevenly across space? How much is due to variation in natural endowments across locations, and how much can be attributed to increasing returns to scale? Separating these two effects can be challenging, in part because the features that first brought people to an area (such as topography, resources, climate, et cetera) are usually persistent and therefore confound attempts to attribute the spatial distribution of activities solely to agglomeration economies. Put another way, it is difficult to disentangle the effects of state dependence (the presence of factors of production) versus serial correlation (the advantages that first attracted other factors). In this study, we consider natural features that were valued historically — by a coincidence of transportation technology and trade patterns - but that were made obsolete some time ago, thus breaking the link between natural advantage and scale.

Our approach to this question starts with portage - the carrying of a boat or its cargo, over land, between navigable waterways, or to avoid a navigational obstacle such as rapids or falls. (Portage also refers to the place where this act is performed.) During the settlement of North America, when the long-distance movement of goods was mostly waterborne, portages were a focal point for commerce. Traders were obliged to stop because of the natural obstacle to navigation; in turn, these sites offered easy opportunities for exchange and commerce. And while these opportunities were valued historically, they became obsolete long ago: thanks to changes in transportation technology, traders no longer walk canoes around rapids. Similarly, although some falls were sources of water power during early industrialization, these advantages also declined with the advent of other, cheaper power sources. Notably, despite the obsolescence of canoe transport and water wheels, concentrations of economic activity continue to exist at many of these sites. In this paper, we examine this persistence of population centers near obsolete portage advantages. Our evidence is most consistent with a model where initial heterogeneity in natural features has helped to select particular locations as city sites, and present-day differences in density and productivity are the result of a process featuring path dependence in the presence of strong increasing returns.

To fix ideas, consider the falls of the James River. In colonial times, an important cash crop in Virginia was tobacco. Tobacco plantations located downriver of the falls of the James had their own wharves and were visited directly by ocean-going ships. On the other hand, these large-forthe-period ships could not navigate through the falls, and tobacco growers farther inland sent their merchandise downriver on canoe-like batteaux. But these batteaux were slow and cumbersome, 
and their pilots sought to offload their goods as far upriver as the ocean-capable ships could meet them. This meant that the falls became a place of exchange. In time, this exchange grew into broader sorts of commerce, and commercial activity in turn gave rise to financial services. In the early and middle 19th century, locks and canals bypassed the falls, and rail lines made the batteaux commerce obsolete, nullifying the area's natural advantage. In spite of the disappearance of its original advantages, the falls of the James is today the site of Richmond, the city that grew up around this colonial tobacco exchange.

We examine early portage sites like the falls of the James throughout the U.S. South, MidAtlantic, and Midwest. In the southeastern and Mid-Atlantic U.S., we pay particular attention to river basins that intersect the fall line, a geomorphological feature dividing the Piedmont and the coastal plain. (The solid lines in Figures 1 and 2 show the approximate boundary of the coastal plain.) The fall line describes the last set of falls or rapids experienced along a river before it empties into the Atlantic Ocean or the Gulf of Mexico. An advantage of examining fall-line portages is that other natural sources of variation are reduced; on land, the transition from coastal plain to Piedmont is quite gradual. This smoothness allows us to use comparison areas-places within the same river basins - that, except for an initial portage advantage, share features similar to these historical portage sites. (This similarity also helps to rule out the existence of features co-located with portage that might be valuable: if flatness is important for road-building, for example, Richmond is essentially as flat as areas nearby along the James River.) In addition to the fall-line portages, we examine portage sites on routes used by French fur trappers in the 18th-century Midwest between the Great Lakes and the Mississippi River system. ${ }^{1}$ We also consider portages on the Mississippi River and its tributaries. In section 2, we describe further the historical importance of portage, give quantitative evidence of its decline, and provide some narratives for selected sites. We present our sample area and the data on historical portages, population, and economic activity in section 3 and the data appendix.

The footprint of portage is evident today, as we show in section 4 with both maps and statistical tests. First, in the southeastern U.S., an urban area of some size is found nearly every place a river crosses the fall line (as seen in Figures 1 and 2). Many of these sites are the current locations of substantial metropolitan areas today: for example, Washington, Philadelphia, and Richmond, as well as smaller cities such as Augusta and Macon in Georgia and Petersburg and Fredericksburg in

\footnotetext{
${ }^{1}$ Indeed, the use of portage to mean carrying your canoe around an obstacle entered North American English around 1700 from the experiences of French fur trappers. The word is not conventionally used to describe the fall-line sites in the South, but we do so here to emphasize the commonality of first-nature advantages across these sites.
} 
Virginia. Moreover, among these portage sites, an area is more densely populated today if it has a larger watershed upstream, which is associated with greater historical demand for commerce. Our results are not sensitive to a variety of different controls for spatial, climatic, or geological features (which might have value today), nor to how we measure the concentration of economic activity, at various levels of aggregation. We also find similar results across various subsamples (including ones that consist of narrow buffers around the fall line or around principal rivers) or with different estimators that correct for spatial correlation. (Portage also predicts density today when controlling for water-power measures, suggesting the greater importance of commerce rather than mills.) We show similar present-day agglomerations at portages between the Great Lakes and the Mississippi River (such as Chicago, Illinois, and South Bend, Indiana) and along the Mississippi, Ohio, and Missouri rivers (such as Louisville, Kentucky, and the Quad Cities of Iowa and Illinois).

In section 4.3, we argue that the persistence of portage comes from initial choices of where factors of production located historically and the subsequent effects of these initial choices, rather than any need to pull a canoe out of the water today. To see this, we replicate our main county-level results, but explore how the correlation between current density and historical portage changes when we condition on the historical density of a number of factors. We find that the predictive power of portage for today's population density essentially disappears when we condition on population density in 1900. This is entirely consistent with our story. On the other hand, the portage coefficient does not change much when we condition on specific investments such as installed water power in 1890 , or railroads circa 1850 . Nor is this result likely due to the persistence of the housing stock in particular, as (i) only a small fraction of the current housing stock was built in the era before portage became obsolete, (ii) this fraction today is actually smaller at portage sites than the rest of our sample, and (iii) housing prices and commute times near portage sites are not significantly different from those in comparably dense areas. (See section 4.4.)

We next consider to what extent these results are consistent with a model featuring increasing returns to scale in local economic activity. It is useful to consider first an alternative model characterized by locally decreasing returns to scale and density differences across space driven entirely by advantages from natural features. If this were the case, portage sites, having lost their natural advantage, should be shrinking. In section 5, we compare the magnitude of the effect of portage on population density in the mid-19th century versus the late 20th century. We find no evidence that these sites have declined relative to comparison areas, and, indeed, the results from some specifications indicate that portages have actually grown relatively faster. 
In section 6, we interpret these results with a model of economic geography, and we relate our findings to other studies in the economics and geography literatures. The model features increasing returns to scale in local economic activity and heterogeneity in initial endowments across many locations. As Krugman (1991a) shows, a common feature in this setup-one that is difficult to verify empirically - is the existence of multiple equilibria. ${ }^{2}$ We interpret a portage's role in completing trade routes as a coordination device: portage helped to resolve the indeterminacy of multiple equilibria by selecting the locations of agglomerations. The subsequent obsolescence of the portage advantage then provides a novel natural experiment to test for the presence of strong local external economies. Our observations of sustained differences in concentration are difficult to explain without multiple potential equilibria, and, by extension, the existence (at some level) of strong scale economies. Taken together, our evidence suggests that it is path dependence in the presence of strong scale economies, rather than heterogeneity in natural features, that accounts for much of the current distribution of economic activity across our sample region.

Our results thus suggest a refined interpretation of related empirical research. In recent work, Rappaport and Sachs (2003) and Davis and Weinstein (2002 and 2008) emphasize natural variation in the productivity or amenity value of locations in determining the spatial distribution of economic activity. While these papers compare locations across very different regions (the coastal versus interior U.S.) or within a geographically variegated country (Japan), we consider areas within the coastal South and Midwest, which contain considerably less interior geographic variation. To understand the contrast among these results, we return to the theory, which predicts that sufficient initial heterogeneity in local natural advantages can actually suppress the existence of alternative equilibria. Put differently, multiple equilibria are more likely to appear if we reduce the variance in natural advantages across space. In contrast, with sufficient variance in natural advantages across sites, the geographic distribution of population should become fully determined.

\footnotetext{
${ }^{2}$ Arthur (1994) surveys an older, mostly theoretical literature that grapples with this point. Cain (1985), Cronon (1991), and Krugman (1993a) also offer evidence, about Chicago, of "first nature" advantages helping to resolve the indeterminacy associated with the existence of multiple equilibria. Rauch (1993) considers the problem of transitions between equilibria. Finally, Redding, Sturm, and Wolf (2010) use German division and reunification to suggest that the persistent change in air-traffic patterns following German division is evidence of a transition between equilibria. Besides the obvious contrast of examining U.S. population instead of German airline hubs, our study benefits from information about a specific geographic feature, and the value of that feature over a long period of time. That portaging is no longer valuable provides an advantageous natural-experiment setting to observe path dependence in the presence of multiple equilibria. There is also some parallel in our work to the integration of monopolistic competition into the Heckscher-Ohlin model of international trade in the 1980s (see, e.g., Helpman and Krugman, 1985). Because of increasing returns, in both trade and geography the location of production might be indeterminate depending on the (initial) distribution of factor endowments. Our contribution is to identify such an initial distribution and point out that subsequent events closely match predictions of a model featuring increasing returns.
} 
This paper is also related to a wider empirical literature that considers natural advantages and the location of economic activity. Although work on location commonly leaves heterogeneity in natural features aside, ${ }^{3}$ recent exceptions include the studies noted above, and Chandler (1972), Kim (1999), Ellison and Glaeser (1999), Holmes and Lee (2009), Hornbeck (2009), and Ellison, Glaeser, and Kerr (2010). In contrast to these studies, we are able to establish the persistence of cities in a setting where, indeed, heterogeneity in natural features is no longer relevant. Our results therefore provide clearer evidence of increasing returns and address the inference problem, correctly noted by many of these papers, when the distribution of underlying natural features is unknown.

There is a still-larger literature that examines the effect of "second nature" factors—advantages not from natural endowments, but from man-made features, whether railroads, manufacturing, or institutions - on productivity and density differences across locations. An extremely selective survey of this literature might include Rosen (1986), Ciccone and Hall (1996), Redfearn (2008), Atack, Bateman, Haines, and Margo (2009), and Donaldson (2010). We provide suggestive results related to this literature in section 4.3, though ultimately the precise identification of all secondary factors contributing to the persistence of portage cities lies outside the scope of this paper. Nor do we attempt to identify the precise sources of increasing returns at the local level; our point is that scale economies must exist at some level to be consistent with our results. In sum, our evidence on the persistence of portage cities in the U.S. points to the effects of natural features-even when those features have no current value. This allows us to interpret our results as a natural experiment providing evidence of multiple equilibria, history dependence, and the existence of strong local aggregate scale economies in explaining differences in density and productivity across locations.

\section{Portage: history and background}

In this section, we discuss the rise and fall of portage and its effects on activity at portage sites. ${ }^{4}$ Throughout the present study, we use the term portage (referring to the activity) somewhat metaphorically. Rather than just referring to the act of carrying a boat around an obstacle, we mean to conjure the broader set of activities that arose because of the obstacle to navigation. These activities

\footnotetext{
${ }^{3}$ In favor of agglomeration economies; see the survey by Rosenthal and Strange (2004).

${ }^{4}$ Sherratt (2006) notes the difficulty in English that the word portage can refer to the action of carrying a boat as well as the site at which it is necessary to carry a boat. He suggests using the term "porterage" or the German term Schiffschleppweg to refer to the place itself. We refer to the place as a "portage site" if there is any ambiguity.
} 
included cartage and other sorts of transshipment, entrepôt trade, water power (if present), and whatever other sectors were required locally to service these activities.

The historical advantage of portage sites derived from their role in completing trade routes. In an early article in the Quarterly Journal of Economics, Phillips (1905) notes that

In the interior [South] the principal group of trade centers [...] were those located at the head of navigation, or 'fall line,' on the larger rivers. To these points the planters and farmers brought their output for shipment, and there they procured their varied supplies. [...] It was a great convenience to the producer to be able to sell his crop and buy his goods in the same market. Thus the towns at the heads of navigation grew into marked importance as collecting points for produce and distributing points for supplies of all sorts (p. 439).

This advantage was made obsolete sometime ago as transportation technology changed. Below, we present brief historical case studies of a few specific portage sites. These are useful in seeing the origins of these sites as well as the obsolescence of portage. Narratives differ some across sites, but the common theme is that their first-nature advantages are largely, if not completely, obsolete. We then gauge the decline of portage-related activities with census data on occupational shifts. (Readers who are only interested in the quantitative evidence should skip forward to section 2.2.)

\subsection{Narratives from a few portage sites}

\subsubsection{The Falls of the James: Richmond, Virginia.}

Most of the settlement in the Virginia colony during the 1600 s took place on the coastal plain. Inland grants of land began in the 1730s, first along the James River. Therefore, there was not much commerce upstream of the fall line before that time. The role of the fall line in providing a focus for commerce was understood early on. For example, in 1733 William Evelyn Byrd, one of the early recipients of inland grants of land, said this of the future sites of Richmond and Petersburg:

These two places being the uppermost landing of the James and Appamattuck Rivers, are naturally intended for Marts where the traffick of the outer inhabitants must center (Henry, 1900, p. 156, original spelling preserved).

As mentioned in the introduction, farmers in the interior would descend the James River in canoelike batteaux to bring their tobacco and other produce to Richmond for trade. The city of Richmond 
was founded in 1742, and by then the site was already a center of exchange, particularly for tobacco. In 1779, the capital of the state of Virginia moved from Williamsburg to Richmond in recognition of the expanded importance of the latter city. In the 1800s, the water power generated by the locks bypassing the falls was used for manufacturing, principally of tobacco products.

In the early 1800s, Richmond saw two large changes in transportation infrastructure: (i) canals and locks and (ii) railroads. First came the construction of the James and Kanawha Canal, which paralleled the James River up to the Shenandoah Valley. It decoupled to some degree the location of water power from the location of the falls because the locks all along the canal could be used to generate power via mill races. The canal was soon rendered obsolete, however, by the coming of the railroad. The initial railroad through Richmond followed the route of the James River, approximately. This meant that Richmond could be effectively bypassed as a transshipment point. For example, before the railroad, coal mined in the interior came down to Richmond and was off-loaded on to ships there for export. Later, coal was loaded on to trains and brought straight to collier ships at the seaport in Hampton Roads. On the other hand, tobacco was still brought to Richmond, which had already established itself as a center of tobacco exchange and processing.

\subsubsection{The Falls of the Savannah: Augusta, Georgia}

In colonial times, the head of navigation for the Savannah River was at the fall line. Sometime before 1716, a trading post was located at this intersection. James Oglethorpe, a founding father of the Georgia colony, described this site as "the key of all the Indian country" in 1739 (Cashin, 1986). Another observer noted that "Indians in canoes brought cargoes of animal skins, which the colonists in turn sent downstream to Savannah" (Federal Writers' Project, 1938). Over the next 50 years, the Savannah watershed upstream of the fall line was settled by Europeans. By circa 1800, Augusta had become an important center of cotton trade, with pole boats carrying cotton bags down to Savannah for export. In the 1820s, 15 steamboats also plied the route between Augusta and Savannah (Federal Writers' Project, 1938). In the 1840s, canals and locks were built at the fall line and at various points upstream to facilitate navigation. These also provided water power in several locations. (Far-larger water-power sources on the Savannah River were upstream of the fall line.) By 1854, Augusta was a stop on a rail line that connected Charleston, South Carolina, to what became Atlanta, Georgia. The importance of the river for trade declined following the advent of the railroad, and commercial river traffic up to Augusta was essentially defunct by the early 1900s. Nevertheless, Augusta maintained its status as a regional center of cotton commerce 
and leveraged this to some degree with a small-scale manufacturing sector that processed cotton. Augusta was also the state capital of Georgia circa 1800.

\subsubsection{The Falls of the Ohio: Louisville, Kentucky}

The contemporary city of Louisville, Kentucky, is located by the Falls of the Ohio. Permanent settlement by Europeans did not begin until the 1770s, when Louisville was founded. In the following decades, river traffic increased markedly and was dominated by small craft such as keelboats and flatboats, which were poled up and down the river. In theory, these boats could pass through the Falls of the Ohio during the spring, when the water level was at its highest. However, this was a risky undertaking, and many, if not most, chose to cart their goods around the falls rather than risk losing them. The scene in Louisville circa 1810 was described as follows:

Through the riverfront street rolled two-wheeled carts, trundling cargo from the wharf above the falls to the quay below it. There, merchandise was reloaded onto waiting barges (Havighurst, 1970, p. 59).

Steamboats, on the other hand, were generally too large to have any hope of passing through the falls, and so the advent of steamboats intensified the importance of cartage at Louisville. This situation changed markedly, however, in the 1830s and 1840s, when a series of locks and short canals allowed boats to go around the Falls of the Ohio safely, while at the same time obviating the need to unload, cart, and reload goods at Louisville. This would have a profound impact on the local demand for labor, as was observed contemporaneously by some of those displaced:

The Louisville and Portland Canal, as constructed and maintained, is precisely one of those improvements for private interests, at the expense of the public good, which is obnoxious to the good of the whole community (Louisville Business Directory, 1844, quoted in Trescott, 1958).

The implications of this quote were rather pessimistic, as it turned out. Louisville had already become a regional commercial hub, a status that continued after the end of portage and cartage. Further, it later became a regional center for manufacturing and finance.

\subsubsection{The Chicago/Des Plaines Portage: Chicago, Illinois}

French fur trappers used the portage between the Chicago and Des Plaines rivers in the late 1600s, although there was very little settlement of this site by Europeans until the mid-1700s. By the time 
the area became part of the United States, its role as a place of transshipment (for things beyond simply beaver pelts) had been established:

From the mouth of the Plein [the Des Plaines River] to the lake, over which there is a well-beaten wagon road, boats and their loads are hauled by oxen and vehicles kept for that purpose by the French settlers at the Chicago (Long, 1808, quoted by Putnam, 1918, p. 9).

The Illinois \& Michigan Canal opened in 1848 and connected Lake Michigan and the Mississippi system with a series of locks and a canal dug by manual labor. This made the portaging of boats obsolete, although Chicago continued as a lakeport, which meant that there would still be demand for transshipment from the larger lake ships to the smaller canal boats for some time. The I\&M Canal was itself superseded in 1900 by the Chicago Drainage Canal. This successor canal was constructed, in large measure, to reduce the flow of sewage into Lake Michigan, but it also allowed for larger ships to pass directly between the watersheds. Two decades later, the Cal-Sag Channel opened, 15 miles south of the Chicago Loop. This canal allowed much of the commercial and industrial shipping to bypass the old portage route, and, indeed, there has been relatively little commercial traffic between the Chicago River and Lake Michigan for many decades. ${ }^{5}$

The opening of these latter canals in the early 1900s notwithstanding, traffic on the I\&M Canal actually peaked around 1880 because the railroads proved to be a more economical means of transport (Putnam, 1918). In the mid-19th century, Chicago became a hub for the railroad network. It is worth noting that, to connect with Chicago as a hub, the rail lines coming from the East had to make a significant northerly turn once they passed the southern shore of Lake Michigan. It is doubtful that a least-cost railroad network would have made this bend had there not been a populated center at Chicago. ${ }^{6}$ From the topography of the region, it is difficult to see why the rail network would have made this turn for some natural reason. These twists and turns are also seen in the Interstate Highway System as it comes through Chicago. Various westbound interstates make marked northerly turns as they pass Lake Michigan, so as to intersect with Chicago. This explains the Chicago peculiarity that many of the interstates labeled East-West actually go North-South locally, and the North-South interstates go East-West.

\footnotetext{
${ }^{5}$ Today, according to information from the Army Corps of Engineers (2009), total tonnage passing from the Chicago River directly to Lake Michigan (via the locks next to Navy Pier) is about $2 \%$ of the tonnage passing through the Cal-Sag. Further, the vast majority of this $2 \%$ is attributable to pleasure boats rather than commercial traffic.

${ }^{6} \mathrm{We}$ are grateful to Lou Cain for pointing this out.
} 
Chicago was able to leverage its status as a transport hub to become a leading center for processing the natural resources of the region. Perhaps one of the more famous examples is how Chicago became "Hog Butcher to the World." Further examples of Chicago's use of the natural resources of the region are detailed in Cronon (1991).

Within this narrative, we see the transformation of Chicago from a nexus of transshipment to a place in which the transshipment was displaced from the city by the congestion generated by other activities. The Cal-Sag Channel is an example of moving shipment activity away from the city center, in part because the area was congested with shipping for local uses, and in part because of the logistical difficulties in expanding the Chicago River, now abutted by tall buildings in the city center, to accommodate larger ships. Chicago remains today a hub of the rail and highway systems, but the city is often so congested that shipment takes place along other routes that avoid the city. Indeed, in Northeast Illinois, the truck route from the east on the Interstates (I-80) simply continues west after passing Lake Michigan, and does not make the northerly turn to Chicago discussed above. Today, trucks headed north of Chicago would most likely use one of the "beltway" interstates on the suburban fringe of Chicago, rather than pass through the old portage or lakeport sites, both of which are now rather congested.

\subsubsection{The St.-Joseph/Kankakee Portage: South Bend, Indiana}

South Bend, Indiana, is located at the southernmost bend of the St. Joseph River, which drains into Lake Michigan. From that river bend, it is a relatively short portage to the headwaters of the Kankakee River, which eventually drains into the Mississippi River. This portage was used by fur trappers (Semple, 1903) and later by European settlers:

South Bend became an early center for transportation activities due to the convergence of routes and the break-in-bulk of freight between river and overland transportation. Transport activities at South Bend, as elsewhere, produced a concentration of people and thus a desirable location for trade and service activities (Gold, 1954, p. 44).

The railroads came to South Bend in 1848, and connected the city to Chicago and Detroit (Gold, 1954). Commercial traffic on the river started its decline at this point and disappeared by 1890 (Fogel, 1964). While there were more abundant natural sources of water power at other points along the river, a dam was built at South Bend to provide water for mill races in the late 1800s. The mill races were abandoned by the 1950s. Notre Dame, a university of national prominence, 
was founded in South Bend in 1842. South Bend also became a manufacturing center in the 20th century.

\subsection{Quantitative evidence on the decline of portage}

Employment data from late 19th- and early 20th-century censuses suggest that portaging activities were relatively important at fall-line portage sites, reached a peak sometime before 1880 , and declined thereafter. As evidence of the decline and obsolescence of the portage advantage, we calculate employment in water transportation at and near fall-line portage sites, using census microdata from 1850-1930 (Ruggles et al., 2010). ${ }^{7}$ Panel A of Figure 3 shows, by decade, the share of a river's total water-transportation employment located in fall-line counties, averaged across 51 rivers. ${ }^{8}$ At the peak in 1880 , the average fall-line county contained $13.1 \%$ of total watertransportation employment along an entire river. Note that this figure uses a denominator that includes water-transportation employment at any seaports located near river mouths. By 1930, that figure had dropped to $2.6 \%$ : the relative size of portaging activities at fall-line counties fell dramatically in the late 19 th century.

Alternatively, consider panel B. Here we display water-transportation employment as a share of total employment ${ }^{9}$ for two categories of counties: fall-line portage counties and all other riveradjacent counties. In 1850, the first year for which data are available, water-transportation employment is already low relative to total employment, accounting for $1.5 \%$ of total employment, on average, at fall-line portage sites. From the trend, the data suggest that portaging was already shrinking in importance for local economies as early as 1850 . In the same year, the average share of employment in water transportation in non-portage river counties was less: about $0.3 \%$. The difference in water transportation employment shares then declined from $1.2 \%$ in 1850 to $0.3 \%$ in 1930. By the early 20th century, both fall-line and non-fall-line counties had near-zero and indistinguishable employment shares in water transportation.

\footnotetext{
${ }^{7}$ Census microdata are unavailable before 1850 and in 1890 .

${ }^{8}$ The Raritan and Schuylkill rivers are excluded from this figure, since we are unable to distinguish portage-related employment from seaport-related employment.

${ }^{9} \mathrm{~A}$ limitation of this exercise is that the industry classifications are not precise, since the census does not consistently report industries and occupations until well into the 20th century. The "water transportation" classification is instead assigned by the IPUMS, and captures only a small group of workers-this may account for the low employment shares observed in panel B. This category includes stevedores, but it likely excludes related activities like laborers and warehousing. On the other hand, it includes non-portage activities, like sailors and navigators. This imprecision could account for differences in the timing of occupational shifts between interior portages and seaports.
} 
Finally, note that, except for the Mississippi, fall-line rivers today are no longer used for significant commercial shipping. Indeed, many of these rivers were not used commercially as early as 1890 (Fogel, 1964, Figure 3.3). By inference, the importance of transshipment activities at fall-line sites must have declined, and probably by the late 19 th century.

\section{Data}

Our broadest study area includes all locations in river basins that intersect the fall line-a wide swath of the southern and central U.S. that includes locations near the headwaters of the Raritan, in New Jersey, as well as places along the Rio Grande, in Colorado, New Mexico, and Texas. (See Appendix Figure A for the full extent of the fall line. ${ }^{10}$ ) This includes over two-thirds of the present-day counties in the U.S., with the excluded areas being mostly in New England (the fall line, as a geomorphological feature, goes underwater near New York harbor), and in areas outside the drainage basins of fall-line rivers, such as the Great Lakes, most of Florida, and states west of the Rockies. Thus, our sample contains both a large number of historical portages (defined as the intersection points between the fall line and major rivers) and, to the extent that locations along the same river are similar to each other, a large number of suitable comparison areas. ${ }^{11}$

The fall line itself is digitized from Physical Divisions of the United States, produced by the U.S. Geological Survey. We intersect this spatial layer with major rivers in the "Streams and Waterbodies" map layer, from NationalAtlas.gov, in order to identify points that were likely historical portage sites.

In contrast, we use historical documents to identify portage sites in the Midwest and Upper South. Portage paths used by fur traders between the Great Lakes and the Mississippi River system are described by Semple (1903, plate following p. 23). For falls/rapids along the Mississippi, Ohio, and Missouri rivers, we process data collected from a number of early 19th-century river surveys performed by the U.S. Army Corps of Engineers, available as part of the Serial Set. More details on these portages and those along the fall line can be found in the data appendix.

To measure the geographic distribution of economic activity, we use population density. Such

\footnotetext{
${ }^{10}$ In Texas, this line is close to the Balcones Escarpment.

${ }^{11}$ Note that our main results are not sensitive to narrower definitions of our sample. In particular, we verify that our results are similar if we restrict our comparison areas to only places that are adjacent to rivers, or places that are relatively close to the fall line. In addition, our main results are qualitatively the same if we limit our study area to the oldest and longest-settled areas east of the Appalachians, where and when initial conditions in transport technology and trade patterns are likely to have valued portage the most.
} 
data are available over a very long period of time: we use county population data at decennial frequency from the U.S. censuses 1790-2000, obtained from the Haines (2004) census extracts. County locations, boundaries, and areas for each census are then drawn from the National Historical Geographic Information System (NHGIS, Minnesota Population Center, 2004) and spatially matched to our portage sites. One drawback of county-level population density is its relatively low spatial frequency. For sub-county areas that are the most densely populated, measurement at the county level will understate the true level of density experienced by households and other factors. For this reason, we also use census 2000 tract population to measure the contemporary distribution of activity at a very high spatial frequency. The tract data afford greater power for contemporary, cross-sectional comparisons, although tracts (or minor civil divisions for that matter) have poor coverage of our sample area historically.

We also use nighttime light intensity, as measured from satellite photos in 1996-97. These data, collected by the US Air Force Weather Agency and processed and disseminated by NOAA, serve as a high-resolution measure of the distribution of contemporary economic activity (National Geophysical Data Center, 2003). The satellite data are both extremely sensitive to variation in visible radiance and available at very high (and regular) spatial frequencies. In addition, they do not rely on the boundaries of census tracts, which are related mechanically to population density. Of course, these satellite data are also unavailable historically.

In addition to data on population and historical portage sites, we use data on other features that may vary over space. For example, we spatially match counties in each decade to data on climate, elevation, aquifers, and more from NationalAtlas.gov and the Climate Atlas of the United States. Also, we use spatial data on the locations of potential water-power sources (U.S. Census, 1885), 18th century seaports (Phillips, 1905), the navigability of rivers in 1890 (Fogel, 1964), and 19th-century railroads (Pred, 1980). Further details on data sources and the GIS work can be found in the data appendix.

\section{Portage sites and contemporary cities}

In this section, we show that pre-19th century portage sites are still likely to be population centers even today, approximately a century after their initial natural advantage was made obsolete. 


\subsection{The Fall Line}

\subsubsection{Maps}

Today, contemporary agglomerations are found at many fall-line/river intersections that were likely to have had rapids or falls. Starting from the northeast, examples include New Brunswick (on the Raritan River), Trenton (Delaware), Philadelphia (Schuylkill), Washington/Alexandria (Potomac), Richmond (James), Augusta (Savannah), Columbia (Congaree), and Tuscaloosa (Black Warrior). West of the Mississippi River, the fall line passes through Little Rock, Fort Worth, Austin, and San Antonio. ${ }^{12}$ This spatial correlation appears along at least two dimensions: both along the fall line, where present-day cities are likely to appear at rivers, and along rivers, where present-day cities are likely to appear at the fall line. We review this pattern here.

Figure 1 displays a detailed map of the fall line as it passes through Alabama, Georgia, and South Carolina. For reference, on the bottom of the figure, we provide a map with state boundaries, major rivers, and points labeling notable places. A few features are evident in the map. First, there tend to be population centers today at the point where rivers cross the fall line. Second, there tend not to be population centers along the fall line, if a river is not present. Take, for example, Augusta, Georgia, which is along the Savannah River, compared to similar but unpopulated locations to the northeast or southwest along the fall line.

We can see the importance of fall-line/river intersections by looking along the paths of rivers. Along a given river, there is typically a populated place at the point where the river crosses the fall line. This comparison is useful in the following sense: today, all of the sites along the river have the advantage of being along the river, but only at the fall line was there an initial portage advantage. Figure 4 shows the results of this exercise, using smoothed lines based on census-tract data from 2000. We select tracts within 50 miles along rivers that intersect the fall line. Then, we assign each census tract a relative location $x$, where the fall line is normalized to location $x=0$, and the Atlantic Ocean is to the left of the origin, $x<0$. In the top panel, relative location is measured using miles from the fall line. In the bottom panel, relative locations are normalized again so each river mouth, at the Atlantic, is measured at $x=-1$, and each river's source is measured at $x=1$. Then, we smooth the data on tract population density using Stata's lowess procedure, with bandwidths of 0.3 (top) or 0.1 (bottom). Both graphs clearly display a peak in (log) population

\footnotetext{
${ }^{12}$ In Texas, the Balcones Escarpment coincides with some well-known springs. Since the nature of initial advantage is somewhat different here, we have verified that our results are not sensitive to the exclusion of sites west of the Mississippi. See the data appendix for a map of this area.
} 
density at the point where rivers cross the fall line.

Another feature is that many of these portage sites have echoes at the coast. That is, many fallline cities have a sister city downriver that serves as a seaport. For example, in Georgia, downriver from Augusta lies Savannah, and, in Virginia, Norfolk lies downriver from Richmond. This fact highlights that the persistence of population at these portage sites is not about participation in ocean-borne trade today. Indeed, almost none of these rivers were used for commercial navigation as early as 1890. In a few instances, fall-line cities attempted to revive steam travel on their respective rivers as late as the 1910s, but these efforts were met with failure because steamboats were nowhere near cost-competitive with the railroads. Therefore, these sites' direct advantage from being at the head of navigation was made obsolete well over a century ago.

The present-day distribution of population across fall-line portage sites is also consistent with our narrative. Recall that the presence of rapids along the river acted as a kind of coordination device that selected the location where trade between settlers in the interior and ships would take place. But rapids were not a sufficient condition, because, if there were no settlers upstream, there would be no commerce to coordinate. Since much of portage's initial value lay in completing trade routes, we see this as a reasonable measure of demand for commerce at the portage site. ${ }^{13}$

The case of Georgia is again illustrative. The Savannah River has a fairly large watershed upstream of the fall line, and this watershed supported a substantial population in the early days of the republic. This ensured that the falls of the Savannah, the current site of Augusta, would become an important trading center. In contrast, consider the case of the next river to the southwest, the Ogeechee. Upstream of the fall line, the watershed that feeds this river is comparatively small. Louisville, Ga., the town at the falls of the Ogeechee, was a trading center, and indeed was briefly the capital of Georgia around 1800. But this town is today about an order of magnitude smaller than its neighbor, Augusta. Moving southwest, the next major river is the Oconee, and the city at the fall line is Milledgeville. The upstream watershed at that site has an area somewhere between the previous two rivers, and, accordingly, Milledgeville is today larger than Louisville (Ga.) but smaller than Augusta.

Farther west, the intersection of the fall line and rivers is also seen in contemporary population density. Still in Georgia, both Macon and Columbus lie at the intersection of the fall line and their respective rivers. Montgomery, Ala., lies just south of the fall line on the Alabama River. (The

\footnotetext{
${ }^{13}$ According to Phillips (1905), little if any trade occurred between river basins in the South-population was widely scattered, and overland transport costs were high. "No traffic of volume [...] might therefore be expected" (p. 440).
} 
case of Montgomery is slightly more complicated because the Alabama River bends and bifurcates into two slower moving pieces just south of the fall line. This implies that the effective head of navigation was somewhat south of the rapids.) Tuscaloosa, Alabama, lies at the falls of the Black Warrior River.

The next major river that crosses the fall line is the Mississippi, but there is no population center at that point. In spite of the Mississippi's vast watershed, this fact is not a challenge to our hypothesis in that the flow of water is so great that no rapids form at that intersection. Continuing west, there are minor settlements at the intersection of the fall line with minor rivers, and larger cities at intersections with larger rivers. Noteworthy are the cases of Little Rock (on the Arkansas River) and, in Texas, Fort Worth, Waco, Austin, and San Antonio. Curiously, settlements at fallline/river intersections are absent in Oklahoma, which may be due to the peculiar manner and relatively late date at which that area was settled.

Farther north, there are settlements at the intersection of the fall line and rivers, and, indeed, major cities at many of the sites with large upstream watersheds. Figure 2 shows detail for the fall line from North Carolina to New Jersey. The case of Richmond was mentioned earlier; it lies at the falls of the James River, whose watershed extends into western Virginia and covers much of the tobacco-growing interior of that state. The first rapids on the Potomac River (not to be confused with the "Great Falls of the Potomac" somewhat farther upstream) lay at the present site of Alexandria, Virginia, and Georgetown, in the District of Columbia. The watershed of the Potomac upstream from that point is large and includes the Shenandoah Valley, which was an important breadbasket region historically. Other major cities at fall-line portage sites include Baltimore, Philadelphia, Wilmington, and Trenton. Furthermore, a few medium-sized cities are found where the fall line intersects rivers with smaller upstream watersheds such as Fredericksburg on the Rappahannock and Petersburg on the Appomattox, both in Virginia. Minor settlements are also found on fall-line portage sites in North Carolina, but the relationship across sites between watershed and population is less evident. These rivers empty into the Albemarle and Pamlico sounds, which were isolated from ocean-going commerce by the often treacherous navigation near and through the barrier islands. (And, indeed, the area just offshore was dubbed the "Graveyard of the Atlantic.")

\subsubsection{Statistical comparisons}

Statistical tests confirm the features shown in the maps. We focus on two measures of initial portage advantage: (i) proximity to historical portage sites, and (ii) watershed area upstream of 
the fall line. We consider three outcome variables: (a) population density in census 2000 tracts, (b) the average intensity of nighttime lights in 1996-97, and (c) population density in census 2000 counties. All three of these variables are transformed into natural logarithms, so that coefficients can be interpreted as percentage differences.

We first investigate whether proximity to a fall-line/river intersection predicts population density in recent data. We estimate:

$$
\ln \text { density }_{g r}=\beta \cdot \text { proximity }_{g}+\mathbf{Z}_{\mathbf{g}} \xi+\delta_{r}+\epsilon_{g r}
$$

where densitygr is the population density of geographic area $g$ (either a county, tract, or night-light observation) lying in river watershed $r, \mathbf{Z}_{\mathrm{g}}$ includes a number of specific characteristics, such as a fourth-order polynomial in (miles) latitude and longitude, and $\delta_{r}$ is a fixed effect for the watershed of each river. We cluster the standard errors at the major-river level to account for spatial correlation across counties within each watershed.

We use five measures of proximity. The first measure is the natural logarithm of distance to the closest historical portage site. ${ }^{14}$ Being closer to a historical portage site was valuable, so we expect this coefficient to be negative. The next three measures are binary variables indicating location within a certain radius of a fall-line/river intersection. The first indicator is set to one if the centroid of the area is within 15 miles of the portage site. The second indicator equals one if any part of the area is within 4 miles of the portage site. (Because counties are larger in area than the other two variables, we cut these radii in half for defining the county indicator variables. This ensures that approximately the same areal fraction of the sample is defined as a portage site across the different data sources.) The third indicator is set to one if both the centroid and the adjacency conditions are satisfied. We expect a positive coefficient on each of these three indicator variables. The final variable, meant as a specification check, measures distance to a placebo portage site, which we construct by choosing places that are both on principal rivers and 100 miles inland from the fall line. Because there is no historical reason why these placebo sites should be special, we expect the coefficient on distance to the placebo sites to be statistically zero.

Proximity to portage predicts greater population density today, as shown in Table 1 . The basic

\footnotetext{
${ }^{14}$ Note that we treat any fall-line/river intersection as a historical portage site, whether we can verify that it was an early trading site or not. This strikes us as the correct choice in that it eliminates the endogeneity of having become a historical trading center and further having survived long enough for that history to have been recorded for us to find it.
} 
specification, which again controls for river/watershed fixed effects and a fourth-order polynomial in latitude, longitude, and their various interactions, is shown in column 1. Being $10 \%$ farther away from a portage site predicts $6 \%$ lower population density in the tract data, and slightly more than $2 \%$ lower density in the lights and county data. The dummy variables for proximity predict $70 \%$ to $170 \%$ increases in density, depending on the outcome variable used and the definition of proximity. (The placebo results are discussed later.)

These results are not sensitive to controlling for a variety of spatial variables, as seen in columns 2-6 of Table 1. Results in column 2 include a full set of state fixed effects, which might be needed if there are differences in state-level policies affecting density. Column 3 presents results controlling for the $\log$ distance to the fall line, to the ocean, to the closest river, and to the closest circa1890 seaport. Column 4 controls for climate variables: the average fraction of days with sunshine and the natural logs of heating degree days, cooling degree days, and precipitation. Columns 5 and 6 include controls for, respectively, the share of the area over a known aquifer and the mean elevation of the area. Coefficient estimates in each of these augmented specifications are similar to the baseline.

Next, we find broadly similar estimates in different subsamples. In columns 7 and 8, respectively, we restrict the sample to be east of the Mississippi River or to include only watersheds whose rivers flow into the Atlantic Ocean. In column 9, we restrict the sample to be only those areas whose centroids are within 5 miles of the fall line. Thus, this specification compares counties within the same watershed that are quite similar along most dimensions, except that some lie on a river and others do not. Our final sample restriction is along the rivers rather than along the fall line; the sample consists of only those areas that are within 5 miles of one of the principal rivers. This comparison is, therefore, similar to the evidence that was presented in Figure 4: all of the areas are close to a river and distance to the ocean moves smoothly over space, but the head of navigation was at the fall line. Estimates from these last two samples are quite similar to those from the basic specification.

We then adopt several alternative strategies to deal with the likelihood of spatial serial correlation in the data. Simply treating each observation as independent would be inappropriate because neighboring areas are very likely correlated among themselves. This is why the basic specification uses standard errors that are clustered by the watershed of each principal river. In column 11 , we instead cluster on state, which could be more appropriate if the relevant factor that induces spatial serial correlation is state-level policy choices. But confining the serial correlation to be within 
arbitrary jurisdictions such as a state might also be inappropriate. As a third clustering strategy, therefore, we follow the methodology of Bester, Conley, and Hansen (2009) and cluster instead on a series of $60 \mathrm{mi}-$ by-60mi grid squares that we defined to completely cover the sampled areas. The results from this estimator are seen in column 12. Next, in column 13, we construct standard errors by bootstrapping on the river/watershed rather than clustering. Finally, in column 14 we use Conley's (1999) estimator that allows for serial correlation within a given radius around each geocoded observation. The Conley estimator is akin to the Newey-West estimator for time series in that it allows for fairly general correlational structures within a predefined range. We opt for a 100-mile cutoff, although results are not sensitive to using other radii. Estimates of the standard errors across these four alternative estimators are quite similar to the baseline, and so we conclude that our inferences are not unduly biased by serial correlation across space. ${ }^{15}$

Finally, we consider a series of placebo portage sites. Recall that we created a pseudo-fallline 100 miles farther inland from the true fall line. The placebo distance variable is constructed according to each location's distance to this pseudo-fall-line and its distance to the nearest river, whereby an area located at the placebo portage site would have a distance of zero by both measures. The estimates of the predictive power of the placebo distance are found in the final row of each panel in Table 1, where the placebo result is reported for each of the specifications described above. These estimated coefficients are (a) smaller in absolute magnitude than the 'true' distance coefficients and (b) not statistically significant from zero. Of the 43 coefficients displayed in Table 1 for the placebo distance, only two are statistically significant, and one of these has the "incorrect" sign. Our model therefore passes this particular falsification test. ${ }^{16}$

Among fall-line/river intersections, the watershed upstream from the fall line predicts having higher population density today. This measure is based on the land area drained by the river of each portage site and is determined by aggregating hydrologic units, from NationalAtlas.gov, north and west of the fall line. As discussed earlier, a larger watershed upstream should have been correlated with greater demand (historically) for commerce at the portage site. We evaluate this idea in Table 2. We estimate:

$$
\ln \text { density }_{g r}=\zeta \cdot \text { proximity }_{g}+\gamma \cdot \text { proximity }_{g} \cdot \ln \text { watershed }_{r}+\mathbf{Z}_{\mathbf{g}} \nu+\delta_{r}+\varepsilon_{g r}
$$

\footnotetext{
${ }^{15}$ Standard errors estimated using the Gauss-Markov or Huber-White assumptions are much smaller than our baseline estimates, which is to be expected if the data are spatially autocorrelated.

${ }^{16}$ This latter result is not sensitive to modifying the distance by which the placebo fall line is shifted, unless the shift is less than 20 miles. But such a small shift does not make for a particularly meaningful placebo exercise in that a city located right at the portage site could potentially impact density 20 miles away.
} 
where proximity $_{g}$ is a binary indicator for portage site and ln watershed ${ }_{r}$ is the natural logarithm of the watershed area upstream of fall line drained by each river $r$. As above, we cluster the standard errors on river/watershed to account for spatial correlation. The default specification again includes fixed effects for each river/watershed, as well as a fourth-order polynomial in miles latitude and longitude. Column 1 displays these estimates. A 10\% larger upstream watershed is associated with a $3 \%$ to $4.5 \%$ higher density at the portage site. By the construction of the variables, the coefficient on the indicator for proximity of the portage site measures the effect for an area with a watershed equal to zero. This coefficient is negative, but is not statistically significant in most specifications. As an alternative specification, we present in column 2 estimates of the watershed/portage-site interaction that fixes the direct portage-site effect to zero. Again the watershed-size effect is positive and statistically significant, although it is quite naturally smaller because we constrain the main effect of portage to be zero. We find similar results if we estimate these models with some additional spatial controls, such as state fixed effects (column 3) or distances to the ocean, to the fall line, to the closest river, and to the closest early seaport (column 4).

Next, we consider the specific mechanism of having the potential of water power at these sites, versus other portage effects. These results are seen in columns 5-7 of Table 2. We proxy water power with the height of the falls at that location, which measures the kinetic energy that can be theoretically extracted per unit of water passing through the river at that area. ${ }^{17}$ The first specification considers the interaction of watershed size with portage site and the interaction of potential water power with water-power site. (The specification is therefore comparable to results in column 2, rather than column 1.) As seen in the table, results for water power are mixed, and the coefficient on the watershed/portage interaction are essentially unchanged from column 2 . The second specification, seen in column 6, compares a binary indicator for portage site with a binary indicator for water-power site. Again, the results for water power are mixed, although at least in this case all of the statistically significant results are of the expected (positive) sign. Nevertheless, the estimates for the portage-site dummy are quite similar to the baseline (seen, for example, in Table 1, column 1, in the fourth row of each panel). Finally, in column 7, we include both sets of measures of water power and watershed, as well as an interaction term between watershed and water power at the portage site. (The specification is most comparable, with respect to interpreting the portage

\footnotetext{
${ }^{17}$ The census volume (1885) that we use also contains information on the horizontal length of the falls and, for a subsample, their estimates of the total potential water power that could be extracted. Using either of these other variables does not affect the results here.
} 
coefficients, to column 1 of the same table.) As above, results for water power are mixed, either considering the extensive or intensive margins. Nor is there much evidence of complementarity between these two factors: the interaction between watershed and water power is insignificant in 2 of the 3 data sets, and is significantly negative in the other. In any event, the coefficients on the watershed term are quite similar to the baseline in column 1.

We find similar results using a few alternative strategies for constructing samples or estimating the model. One approach, seen in column 8, is to only use a sample that is close to the fall line. These estimates are essentially similar to the baseline. We also use samples in which we look only at the portage sites or only at the portage or water-power sites; and these results are seen in columns 9 and 10. Compared to the results from the county data, the watershed interaction is less predictive of population size in the tract or lights data. As before, controlling for the direct effect of water power does not materially alter the conclusion about the watershed interaction. Finally, we repeat the use of alternative estimators for standard errors that was described in detail for Table 1. The statistical inferences that we make using these alternative standard errors are broadly similar to those that we made using the baseline specification.

\subsection{The Midwest and Upper South}

The correlation between historical portage and the current distribution of economic activity is not unique to the American South: present-day agglomerations occur at many Midwestern portage sites as well. The most well-known Midwestern example is Chicago, as detailed in Cronon (1991). But various portage routes between the Great Lakes and the Mississippi River system were used, and many of those routes today have portage-descended cities. Figure 5 shows the locations of portage routes circa 1700 between the Great Lakes and the Mississippi River (from Semple, 1903). These routes connected rivers flowing into the Great Lakes with small tributaries of the Mississippi or Ohio rivers. In the case of Chicago, the portage occurred relatively close to Lake Michigan. Along the continental divide that separates the Mississippi watershed from the Great Lakes watershed, contemporary cities located near early portage routes include (from the northwest) Portage (Wisconsin), Chicago, South Bend, Fort Wayne, Akron, and Erie. In addition, many present-day cities are located at the Great Lakes mouths of these portage routes, including Green Bay (on the Fox River), St. Joseph, Michigan (on the St. Joseph), Toledo (Maumee), and Cleveland (Cuyahoga).

There were also a number of obstacles to navigation along Mississippi River tributaries that 
required portage. Figure 6 shows 19th-century locations of falls and rapids or heads of navigation (as open circles) along three major tributaries of the Mississippi River-the Ohio River, the Missouri River, and the upper Mississippi River. Populated areas are seen near each set of (historical) falls. The number of examples is so small that it is convenient to discuss them individually: the Falls of the Ohio are located at the site of present-day Louisville, Kentucky. Next, falls and rapids along the upper Mississippi were located near Minneapolis (the Falls of Saint Anthony), at the Quad cities in Iowa and Illinois, and near the Iowa/Missouri border, in Keokuk, Iowa. Finally, two navigational heads of the Missouri River existed at Sioux City, Iowa, and Great Falls, Montana. In addition, river confluences - the joining of two rivers-were another potential cause of transshipment, because many of these confluences coincided with changes in river depths and the need for different kinds of craft on different river sections. Examples of cities at confluences are Kansas City, Paducah, Cincinnati, and several others. These are not part of our main argument, however, because there might be persistent advantages of confluences if the tributary is still used for shipping.

\subsection{Reproducible factors and persistence}

Next, we consider some mechanisms for the persistence of density at portages. Since the specific advantages that came from portage have long since disappeared, we suggest that the higher population densities at portages today are not directly related to pulling canoes out of the water, but are instead functions of these initial conditions having attracted economic activity in the past.

One way to separate the direct versus indirect effects of portage is to see how the coefficient on the portage advantage changes as we control for the presence of reproducible factors of production at various points in time. These results are seen in Table 3, where the baseline results are repeated in column 1. (This analysis is restricted to the fall-line sample used in section 4.1 because the other portage sites that we identified were too few in number to permit a detailed statistical examination.) Panels A-C use the main sample, which contains all counties in fall-line/river watersheds. ${ }^{18} \mathrm{We}$ then replicate the specifications in panels $\mathrm{A}$ and $\mathrm{B}$, displaying the portage coefficients only, in a subsample of counties within 150 miles of the fall line (panel D) and in a subsample of southern counties only (panel E). The outcome variable is the log of population density in the year 2000.

\footnotetext{
${ }^{18}$ We use data on counties exclusively in this table because we are comparing population density today to data from the past two centuries. These historical data are measured with enough granularity and error that we deemed it unwise to match them to higher resolution data such as tracts or lights data.
} 
We consider three reproducible factors as possible intermediating variables: population density, installed water power, and railroads. In columns 2-4, we condition on population density in 1850 , 1900 , and $1950 .{ }^{19}$ Conditioning on population density in 1850 yields a coefficient on portage that is always lower than the baseline, in some cases by more than a third. This suggests that portage advantages were still at work in 1850 in spurring growth at portage sites. (The regressions with lagged population density can be thought of as partial-adjustment models.) If we instead condition on the 1900 population density, the coefficient on portage is one half to two thirds smaller than the baseline. Finally, if we condition on population density in 1950, the portage coefficients are close to zero and statistically insignificant. This suggests that whatever direct effect portage had on population density was steadily declining by 1850 , and had dissipated by 1950 , and any persistence in population at that site was due to reproducible factors that were already there by the early 20th century. (Results for columns 2-4 are quite similar if we restrict the sample only to those counties with population defined in 1850 or if we restrict the coefficients on the lagged density to unity.)

We next consider measures, from 1880, of water power that had already been harnessed (Census, 1885). We think of this as a reproducible factor rather than a natural endowment insofar as there were many sites with the potential for water power, but only some where water power was developed and installed. These results are seen in columns 5 and 6. Estimates on the portage coefficients are essentially unchanged by the inclusion of a dummy for, or a continuous (log) measure of, water power.

We consider the role of early railroad development as intermediating variables for the portage effect. Using maps from Pred (1980) for 1850, we construct a dummy variable for the presence of a railroad, a continuous variable for the size of the railroad network to which that county is connected, and (log) distance to the nearest railroad hub. (Results here are not sensitive to using the same variables for 1840 or 1860.) These early-railroad variables are strongly predictive of population density in 2000. However, the inclusion of these variables results in no more than a $20 \%$ drop in the portage estimates relative to the baseline. Controlling for combinations of these early-railroad variables simultaneously does little to change this latter result. Thus, while the early

\footnotetext{
${ }^{19}$ Changing county boundaries pose a problem for measuring lagged population density. We address this with a series of spatial joins within ARCGIS. This yields the approximate population density in an earlier census that lay within the current county boundaries. See the data appendix for details. Moreover, to account for the fact that some regions were settled earlier than others, we allow the lag of population density to interact with a second-order polynomial in latitude and longitude. Prior to constructing an interaction term, we subtract Richmond's latitude/longitude from the coordinates, so that the main effect of lagged density (whose coefficient is displayed in the table) is evaluated at Richmond.
} 
rollout of the railroad network may have been an important variable, it is apparently not the central mechanism by which the effect of the portage-related initial conditions were transmitted to today.

Finally, a reproducible factor that might mediate the effect of portage on the location of economic activity is housing. Although housing is long-lived and fixed in location, note that its location is a function of initial conditions, and houses tend to depreciate over time. It is also likely that, like other reproducible factors, the presence of housing might improve the value of local marginal product or utility of new economic activity, in order to allow for increased density. However, given the depreciation of housing over time, we actually find it an unlikely candidate factor to explain the persistence of population centers at historical portage points. In fact, in our fall-line sample in 1990, fewer than $15 \%$ of houses in portage-site counties were older than 50 years old, compared to $20 \%$ of houses in other counties in the watersheds of fall-line-crossing rivers (Haines, 2004, and authors' calculations).

More generally, any explanation that is based purely on a sunk cost is problematic for two reasons. First, like housing, most things that we think of as sunk/fixed costs do indeed depreciate at long horizons, and therefore are not truly sunk. ${ }^{20}$ Second, in the time period that we consider, the country's population increases almost two orders of magnitude, and such an increase in population could not be contained in the circa-1900 housing stock, however well maintained. Put another way, it is important to recognize that housing, while a fixed investment with respect to a particular plot of land, is not a fixed cost at the level of a whole county. When new people arrive, new houses need to be built. Thus, for a sunk asset to explain some of our results, it would have to be because of a cost that was fixed at the level of the city. Perhaps such pure fixed-cost assets do exist at a city level, such as the incorporation of the city itself or the initial surveying and platting of the site. If such fixed costs were indeed very large, it suggests that increasing returns are important mainly at the low end of the scale of density: once a town/city is established, it should persist. However, a model with such a fixed cost provides a less compelling explanation for our results using the upstream watershed, which produced considerable variation along the intensive margin of population density.

\footnotetext{
${ }^{20}$ Further, history provides various examples of little-used rail lines whose tracks were pulled up and re-deployed elsewhere, which suggests that specific factor is not completely sunk even in the short run.
} 


\subsection{Contemporary housing prices and commuting times}

Relative to comparison areas, portage sites have higher housing prices today, but this result disappears when conditioning on local population density. These results are seen in Table 4, where we estimate equations (1) and (2) again, but use the natural logarithm of a housing price on the left-hand side instead of population density. The price data are medians at the county level, and are drawn from census data as found in Haines (2004). We use data on median prices in 1990 and 1940, as well as data on median rents in 1990. As above, we estimate models with a dummy for portage site (panel A) and an interaction of watershed times portage site (panel B). Odd-numbered columns report the basic specification, in which we see that the portage variables predict higher housing prices. The dummy for portage site predicts about 15\% higher housing prices in 1990, and $30 \%$ higher prices in 1940. The upstream watershed from the portage site similarly predicts a higher housing price in the same years, with a doubling of the watershed size predicting a 4\%-8\% higher housing price. ${ }^{21}$ Even-numbered columns contain estimates from a specification that controls for a sixth-order polynomial in population density. When controlling for population density, the coefficients on portage are 60\%-90\% lower in absolute magnitude, and in no case are they statistically significant. This indicates that, while portage sites have more expensive housing, this price differential is consistent with the relationship between price and density in the whole sample.

This suggests that portage areas are neither in decline nor are they simply hanging on because their housing stock has not yet fully depreciated. Relative to areas of the same density, housing should be cheap in a declining area, to the extent that the natural rate of decrease in population is faster than the depreciation of the housing stock (Glaeser and Gyourko, 2005). But this does not seem to be the case for portage sites, which suggests that they are neither in relative decline nor stanching the outflow of population by having relatively cheap housing. Even if population were immobile, declining areas would still have lower relative housing prices, as the decline in personal income would translate into an inward shift of the housing-demand curve. Either way, these results do not point to portage sites being in decline following obsolescence of the portagerelated advantages.

\footnotetext{
${ }^{21}$ Recall that the coefficients for population density on portage were 1.6 and 0.2 for, respectively, the dummy and watershed interaction. These are about a factor of 10 larger than the coefficients of price on portage. If the history of portage had no direct effect on prices today (except through density), the portage variables would be excludable instruments for density in a 2SLS regression of price on density. The ratio of coefficients discussed here (an ILS estimate) implies an elasticity of housing prices to population densities of 0.1 , which is similar to the OLS estimate in this sample.
} 
A similar argument holds for durable transportation infrastructure investments like roads or highways. In columns 7 and 8, we find no evidence that commute times are significantly lower in portage cities relative to other similarly-sized cities. Such a finding might suggest that portage areas are attractive primarily because of an excess supply of highways, but these results do not support such an interpretation.

\section{Responses following portage obsolescence}

We show here that portage sites have not been in decline relative to comparison areas. In fact, there is some evidence that economic activity has become increasingly concentrated at historical portage sites-long after portage obsolescence. To show this, we examine data on population density from 1790 to 2000 for our sample of counties. This finding is common across the fall-line sample, the Mississippi-River system, and the watershed boundary between the Great Lakes and the Mississippi River.

We regress log population density on log distance to portage in each census year, as in equation (1), obtaining estimates of the proportional increase in density associated with portage in each decade. As before, the basic specification includes a polynomial in latitude and longitude and a set of fixed effects by the watershed of each river that crosses that fall line. The coefficient estimate, $\hat{\beta}_{t}$, is a measure of the relative concentration of economic activity near portage by year. In particular,

$\hat{\beta}_{t}=0$ suggests that population is uniformly distributed across portage and non-portage counties within the same river watershed, and $\hat{\beta}_{t}<0$ suggests that people are concentrated at portage sites.

Panel A of Figure 7 shows $\hat{\beta}_{t}$ in each census year $t$; the last point estimate, for $t=2000$, is similar to those reported in the specifications shown in Table 1, panel C. As before, we can reject the hypothesis that population is uniformly distributed along rivers in 2000 . But, the path in $\hat{\beta}$ across decades suggests that economic activity is similarly concentrated today as it was in 1800 . Although there is some evidence of population spreading out after 1850 (the coefficient attenuates towards zero), this is neither statistically significant nor persistent.

In panel B, we show results of decadal regressions of population density on upstream watershed size in each year, as in equation (2), to obtain estimates of $\hat{\gamma}_{t}$ for each census year $t$. This coefficient estimate yields a measure of the relative concentration of economic activity at "better" historical portage sites, along the fall line, by year: $\hat{\gamma}_{t}>0$ suggests that population density increases with upstream watershed size. The last point estimate is similar to those reported in the specifications 
shown in Table 2. This figure suggests that population becomes progressively more concentrated over time at portage sites with larger upstream areas.

Controlling for other fixed characteristics yields a qualitatively similar pattern of estimates over time. ${ }^{22}$ If, for example, tastes for good weather increased over our sample period, and a historical portage site happened to have the best climate compared to other counties along the same river or along the fall line, then a continued concentration of factors at a portage site could be due to the change in preferences for climate. For this reason, we include a vector of other county characteristics in $\mathbf{Z}_{\mathrm{g}}$ - such as U.S. state fixed effects, distances to the nearest river, harbor, and the Atlantic Ocean, additional spatial trend terms, climate, elevation, the presence of aquifers, and water power.

To test more formally whether portage areas are in relative decline, we pool the sample of fall-line counties across decades in order to perform a difference-in-difference estimation. The first difference is counties having portage advantage or not, measured by portage distance and upstream watershed area. The second difference is the 19th versus the late-20th century: i.e., during and after portage relevance. We exclude decades around 1900 because they likely include the decline of portage-specific activities. The specific equation to be estimated is as follows:

$$
\ln \text { density }_{\text {grt }}=\zeta \cdot \text { portage }_{g}+\gamma \cdot \text { portage }_{g} \cdot \text { post }_{t}+\delta_{r t}+\tilde{\varepsilon}_{\text {grt }}
$$

where portage $_{g}$ is either the distance to, or watershed upstream, from portage, and $\delta_{r t}$ is a fixed effect for watershed $\times$ decade. Note that this is not a true difference-in-difference; since county boundaries change over time, we cannot include county-level effects. The specifications instead are similar to equations (1) and (2), except that we allow for the coefficients to vary across time. We correct the inference for spatial autocorrelation by clustering at the watershed level.

The results of these regressions can be found in Table 5. In panel A, the regression results suggest that (taking column 1) holding other county characteristics constant, population density is higher, 30.0\% logarithmic, at portage counties along rivers after portage obsolescence. Similarly, in panel $\mathrm{B}$, the concentration of population with respect to watershed size shows no sign of abating after portage obsolescence. These patterns confirm those seen in Figure 7: if anything, population density is more concentrated today near fall-line portage sites than it was in portage's heyday.

We have also experimented with specifications that include a proxy for direct damages from the

\footnotetext{
${ }^{22}$ These results are available upon request.
} 
Civil War. We use a measure developed by Paskoff (2008). His study reports, by county, whether there were battles, occupations, or other reports of specific damage, across the former Confederacy. He refers to such counties as "war counties." Paskoff reports that war counties were more densely populated prior to the war, and, relative to non-war-counties, did not experience statistically significant changes in population or capital stock between 1860 and 1870 . This suggests that either (i) his measure is a poor proxy for large-scale destruction or (ii) war counties recovered quickly. Consistent with this, when we estimate models like that of column 2, but also include a dummy for war county and its interaction with 1850 population density, we do not estimate a significant effect on the latter interaction term. Our hypothesis is that portage works as a coordination device, and thus we would expect that large-scale devastation could 'un-coordinate' people from a devastated location. (This is the logic of the studies of Japan by Davis and Weinstein, 2002 and 2008.) However, it is doubtful that the damage that Paskoff measures from the Civil War was, on average, of sufficient magnitude to affect the equilibrium. In section 6 , we present a model in which the population density of the location can be characterized by multiple equilibria, and each equilibria is locally stable. If so, it could require fairly substantial damage to get knocked down to the low-density equilibrium.

The remaining columns in Table 5 display robustness checks for our results, using different portage indicator variables or different samples. In columns 2-4, we adjust the definition of our portage indicator variable. In column 5, we use only those rivers with falls or rapids at the fall line that we have been able to verify in historical records. In columns 6-7, different sets of decades represent the 19th and late 20th centuries. Columns 8-11 display regressions using different samples. In column 8, we use a consistent geographic sample of only Atlantic rivers, so it is relatively undiluted by westward expansion. Estimates in column 10 use a sample that is zoomed-in to within 50 miles of the fall line. Finally, column 11 uses the entire southern U.S. as the sample, which excludes from the sample the parts of the watershed that extend into the Midwest or above the Potomac.

The results shown in this table echo the graphs in Figure 7. Importantly, the coefficient estimates on our measures of portage advantage show no sign of attenuating towards zero over time. Instead, there is some evidence that economic activity has become increasingly concentrated at historical portage sites, long after the obsolescence of the natural advantages of these sites.

These patterns hold for the aforementioned portage sites in the Midwest and Upper South, as well. (These were the sites referenced in Figures 5 and 6.) For the portages between the 
Great Lakes and Mississippi River, we estimate decadal county-level regressions of log population density on the log distance historical portage sites, as in Table 1, using counties within 12.5 miles of the watershed boundary between the Great Lakes and the Mississippi River. Estimates of $\hat{\beta}_{t}$ by census decade are reported in Figure 8, panel A. The qualitative dynamics are similar to the fall line results reported in Figure 7. Importantly, the advantage of portage shows no sign of abating towards zero over time. Panel B displays estimates of $\hat{\beta}_{t}$ using a sample of counties within 12.5 miles along three principal tributaries of the Lower Mississippi River. Again, in both panels, the dynamics are similar to those reported along the fall line and along the Great Lakes watershed divide.

An alternative approach to measuring whether portage sites were in relative decline would be to compare them with places that were comparably dense historically. Note that this exercise was already done in section 4.3. Recall that conditioning on population density in the early 1900s rendered the coefficient on portage insignificant in both the economic and statistical sense. Those results are therefore consistent with what we find here using the pooled cross-section of counties.

These results suggest several conclusions. First, the concentration of economic activity near historical portage sites highlights the persistence of density even after initial economic advantages have since disappeared. This could be due to strongly increasing returns to scale, or simply very sluggish adjustment to a new, lower equilibrium density. The continuing, and possibly increasing, importance of having been a portage weighs in favor of a model featuring aggregate increasing returns, in which returns are stronger than ever. In the next section, we interpret our results in the framework of such a model.

\section{Discussion}

Here we outline a simple model in the spirit of Krugman (1991a) featuring persistent differences in population density across locations, even absent differences in natural advantages. ${ }^{23}$ These persistent differences in population can be explained by path dependence in the presence of strong aggregate increasing returns. Other plausible mechanisms, including large sunk or moving costs, are also considered, but our evidence suggests these factors are unlikely to be responsible for the persistence of population density a century after portage obsolescence. We use the model to help

\footnotetext{
${ }^{23}$ Alternative modeling strategies are unlikely to change the main predictions. Some examples of other relevant models of urban systems, where differences in natural value are either assumed or allowed include Henderson (1974), Rauch (1991), Krugman (1993a and 1993b), Fujita and Mori (1996), and Rossi-Hansberg and Wright (2007).
} 
illustrate our empirical results and compare them to those elsewhere in the existing literature.

\subsection{A simple model of economic geography}

Consider a static, general-equilibrium model of the spatial economy featuring two kinds of agglomerating forces: heterogeneity in the natural amenity or productivity value of locations and scale economies to the geographic concentration of economic activity. These centripetal forces are balanced with congestion costs that discourage all economic activity from concentrating in a single black-hole location. There are $G$ distinct geographic areas $(g=1,2,3, \ldots, G)$, where $G$ is a large number, covering the entire spatial economy. Without loss of generality, locations have normalized land area of 1 and other fixed endowments. A large number of factors $X$ are freely mobile, at least in the long run. For exposition, we call these factors people, but other factors, like capital, can be explicitly incorporated (see Chatterjee, 2006). $X_{g}$ households are located in location $g$, each inelastically supplying one unit of labor to the production of a (costlessly) traded homogeneous good $y$. Household location choice is the central endogenous decision in the model.

The traded good $y$ is produced at the plant level according to $y=\phi_{g} \sigma\left(X_{g}\right) f(x)$, where $x$ measures factors used by the plant and $\phi_{g}$ captures the effect of location-specific factors on productivity. Natural features enter the model through $\phi_{g}$. Goods are costlessly traded across locations, but one way to interpret portage is as a transport-cost advantage-portage's role in completing a transportation route makes (locally) available more output net of transport costs. A reduced-form function of total factor density $\sigma\left(X_{g}\right)>0, \sigma^{\prime}(\cdot)>0$, accounts for local scale economies not internalized by plants. While an individual plant may face constant or decreasing returns to scale in its own factor inputs (i.e., in $f$ ), its choice of factors can create positive externalities to other plants in the same location - for instance, by raising the marginal product of other factors in that location. These aggregate increasing returns can come from many possible microfoundations-input sharing or knowledge spillovers, for example-but we abstract from their sources (for example, see Duranton and Puga, 2004, for a review). The important feature, preserved here, is that doubling factor inputs in one location will more than double total output in that location, not because of any plant-level production technology but because of (pure or pecuniary) externalities that locally improve marginal factor products.

People receive utility from consuming $y$ according to $U=\psi_{g} y / \tau\left(X_{g}\right)$, where $\psi_{g}$ captures location-specific consumption amenities and $\tau\left(X_{g}\right)>0$ is a reduced-form function that captures 
disutility from crowdedness. ${ }^{24}$ These congestion costs in utility prevent the formation of economic "black holes." As with aggregate increasing returns, we leave the source of congestion unspecified-it might be due to competition for fixed factors in limited supply, or other negative externalities such as crime or pollution. Both $\sigma$ and $\tau$ are used to incorporate, in a general way, local aggregate increasing returns and congestion costs.

\subsection{Equilibrium}

In equilibrium, the labor and goods markets clear. Traded-good plants behave competitively, taking population densities $X_{g}$ and factor prices $w_{g}$ as given. Using the price of the traded good as numeraire, free entry and zero profit conditions yield equilibrium factor prices (wages) in each location: $w_{g}=\phi_{g} \sigma\left(X_{g}\right) f^{\prime}(x)$. Substitution yields the log indirect utility for the marginal mobile person in location $g$ :

$$
\ln V_{g}=c+\left(\ln \psi_{g}+\ln \phi_{g}\right)+\ln \sigma\left(X_{g}\right)-\ln \tau\left(X_{g}\right)
$$

where $c$ reflects economy-wide prices, the second term $\left(\ln \psi_{g}+\ln \phi_{g}\right)$ captures the effects of location-specific amenity and productivity advantages on utility, the third term $\ln \sigma\left(X_{g}\right)$ is the positive effect of agglomeration economies on utility, and the final term $\ln \tau\left(X_{g}\right)$ is the negative effect of congestion on utility. Equilibrium is characterized by a number $V^{*}$ and a vector $\left(X_{g}^{*}\right)_{g=1}^{G}$ such that indirect utility is the same across locations and $\sum_{g} X_{g}=X$.

Taking the outside-option utility $\left(V^{*}\right)$ as given, equilibrium at a particular site $g$ can be analyzed by considering how local indirect utility $V_{g}$ varies as a function of factor density $X_{g}$. We consider two cases: (i) $V_{g}$ is monotonically declining in $X_{g}$ and (ii) $V_{g}$ declines with $X_{g}$ everywhere except over some intermediate range of density at which $V_{g}$ rises with $X_{g}$. In case (i), the economy has decreasing or weakly increasing returns - that is, if for all levels of density, congestion costs increase at a faster rate than agglomeration economies, $\tau^{\prime}\left(X_{g}\right) / \ln \tau\left(X_{g}\right)>\sigma^{\prime}\left(X_{g}\right) / \ln \sigma\left(X_{g}\right)$. Utility increases in factor density only if the magnitude of external economies (in $\sigma$ ) is large relative to the magnitude of disutility from density (in $\tau$ ). We refer to this as strongly increasing returns to scale. Case (ii) satisfies this definition over an intermediate range of $X$.

\footnotetext{
${ }^{24}$ Helpman (1998) uses the consumption of rival non-traded goods to generate this feature from microfoundations. Just as large congestion costs prevent dense locations from getting ever more populous, convexity in $\tau^{\prime \prime}\left(X_{g}\right)>$ $\sigma^{\prime \prime}\left(X_{g}\right)>0$ allows for disutility from "sparseness" and helps to prevent locations from emptying out completely.
} 


\subsubsection{Case (i): Decreasing or weakly increasing returns to scale for all $X$}

Consider the case featuring relatively strong congestion costs and weak increasing returns, depicted in panel A of Figure 9. For each of three locations (differing only in $\phi_{g}$ ), indirect utility $V$ is shown as a function of factor density $X$. The horizontal (dotted) line shows the equilibrium utility level $V^{*}$ achieved in other locations in the economy. The spatial equilibrium can be seen where the marginal household's indirect utility is $V^{*}$, at the point of intersection with the horizontal line. ${ }^{25}$

The utility curves in panel A are downward sloping - congestion costs outpace increasing returns over the entire range of population density. If indirect utility monotonically declines in density, then differences in the value of natural features $\phi_{g}$ fully determine differences in population density across locations. In other words, there is a one-to-one mapping between observed differences in population density and differences in natural advantages.

Suppose location 1 is a portage site and location 2 is a nearby place along the same river. The value of portage in an initial time period of $\phi_{1}-\phi_{2}$ generates a difference in equilibrium density of $X_{1}^{*}-X_{2}^{*}$. Following obsolescence of portage, if these locations are identical in other respects, we expect no (long-run) differences in population density. Graphically, $V_{1}$ and $V_{2}$ would overlap, yielding identical equilibrium population densities. Thus, a parameterization where congestion costs dominate returns to scale predicts that, as $\phi_{1}-\phi_{2}$ goes to zero, so should $X_{1}^{*}-X_{2}^{*}$ converge to zero. As seen earlier, we can reject the hypothesis that differences in population density between portage and non-portage sites have attenuated towards zero. This evidence, combined with the results from panel A, suggests that it is difficult to reconcile observed differences in population density between identical locations if there exist locally decreasing, or even weakly increasing, returns to scale.

\subsubsection{Case (ii): Strong increasing returns to scale at intermediate densities}

Path dependence in the presence of strong aggregate increasing returns can account for persistent differences in population density between otherwise-identical locations. Suppose that, for some $0<X_{g}<\infty$, it is the case that $\tau^{\prime}\left(X_{g}\right) / \ln \tau\left(X_{g}\right)<\sigma^{\prime}\left(X_{g}\right) / \ln \sigma\left(X_{g}\right)$ : in words, there is some level of population density where the degree of increasing returns is greater than the degree of congestion costs, and indirect utility increases with density. Panel B of Figure 9 illustrates this

\footnotetext{
${ }^{25}$ To see this, consider the case if location 1 is slightly less dense than this point. Then, utility in location 1 is higher than in other locations; the marginal mobile household would choose to relocate to location 1 , increasing its density until equilibrium utility is the same across locations.
} 
case. Strong aggregate increasing returns are responsible for the hump shape ${ }^{26}$ of the indirect utility curves - as drawn, the range over which $V$ increases is the range where increasing returns overpower congestion costs. (Again, for the purposes of the present study, we remain agnostic about the precise source and scope of these scale economies.)

The key implication of strong increasing returns and the S-shaped utility curve is the possibility of multiple stable spatial equilibria. This feature is critical for allowing differences in long-run population density between two locations - say, along the same river - that are nearly identical. Consider the center utility curve (the thick black line) in panel B, which could represent two overlapping utility curves for identical locations. There are two stable equilibrium population densities - either the leftmost or rightmost point where $V=V^{*} \cdot{ }^{27}$ Thus, in the strong increasing returns case, there are two potential mechanisms that explain why locations differ in population density. Locations may differ in natural advantages, as before. But, it could also happen that two, otherwise-identical locations have different equilibrium population densities. Notice, however, that the S-shape is not a sufficient condition for multiple equilibria: the greater the vertical distance between $V$ curves, the more likely that alternative spatial equilibria are suppressed. As drawn, differences between location 1 and location 2 in panel B imply a unique long-run spatial equilibrium, in spite of the presence of strong increasing returns. We return to this issue in section 6.5.

To summarize, differences in only natural features $\left(\phi_{g}\right)$ can be sufficient to explain observed differences in factor density across locations. However, in the absence of heterogeneity in natural advantages, only path dependence and strong increasing returns can explain persistent differences in population density, provided that alternate equilibria are selected. How might this equilibrium selection take place? Given reasonable dynamic adjustments, differences in historical density, perhaps driven by initial heterogeneity in natural advantages, would help select different equilibrium population densities across locations.

\footnotetext{
${ }^{26}$ This feature is general to many models featuring agglomeration economies. Imagine instead that the degree of increasing returns is greater than the degree of congestion costs for all density levels. The resulting equilibrium is that a single location receives all households, and all economic activity concentrates in a single, black-hole location-a result for which it is easy to provide a counterfactual. Alternatively, the relevant ranges over which increasing returns outpace congestion costs could be different, as might be the case if agglomeration economies came from multiple different sources. The visual implication of such a parameterization might be multiple large and small "bumps" in the utility curves, followed by a flat or declining curve. This case would imply possibly many more equilibria. There may be a knife-edge case, too, in which indirect utility is flat over some range(s) of $X$. This could imply a continuum of equilibria, but note that it still requires economies of scale that are (just) large enough to compensate for congestion costs.

${ }^{27}$ The middle intersection is not locally stable, and therefore we disregard it.
} 


\subsection{Interpreting portage}

The rise and fall of portage provides a test for the presence of strong local external economies in productivity differences across locations. As noted earlier, portage's role in completing trade routes suggests an interpretation that more output was available at these locations net of transport costs. If $\phi_{g}$ was higher in these locations, this can explain initial differences in population density.

In contrast, we presume that today-outside of indirect effects via the location of reproducible factors-productivity or amenity differences across locations due to portage are negligible. By comparing locations along the same river or other portage sites, we minimize other sources of variation in natural advantages. The areas surrounding our portage sites-the relatively flat and homogeneous areas within the Coastal Plain, the Piedmont, and the Midwest-provide suitable comparison locations where differences in natural consumption amenities $\left(\psi_{g}\right)$ and other productive natural features $\left(\phi_{g}\right)$ are likely to be small. In this case, persistent differences in output and factor density can be explained by path dependence in the presence of strong increasing returns.

Our interpretation is that portage served as a coordination device. The portage advantage directed factors to a portage sites historically, but the factors of production did not leave after the obsolescence of portage-related activities. Instead, the above-average factor density at that time was enough to push those sites into the high-population equilibrium of the model. Notice that both historical density and strong increasing returns are required for this interpretation. Without increasing returns, there would be no reason for the continual reinvestment in factor density following obsolescence of portage. Without the historical density, it might have been impossible for factors to coordinate on that location, because the low-population equilibrium is locally stable.

\subsection{Dynamics, moving costs, and sunk factors}

Our discussion so far has relied on comparative statics, and although many aspects of the model are general, it lacks explicit dynamics. Following Krugman (1991a), reasonable specifications of a dynamic adjustment process can reproduce our model's results. The presence of some adjustment frictions, like moving costs, are necessary conditions for path dependence in our model. Historical densities should only matter for subsequent location decisions if factors cannot adjust instantaneously to changes in the value of natural advantages.

Similarly, the model has so far omitted factors that might be considered sunk, say, locationspecific investments that are long-lived, like housing, railroad tracks, and land surveying and plat- 
ting, or psychological costs, like attachments to places of birth. The presence of large sunk costs, much like large moving costs, plausibly slows down the speed of adjustment to new spatial equilibria. In that sense, they can also strengthen the case for path dependence. ${ }^{28}$ But our evidence presented in sections 4.4 and 5 suggests that no single factor is likely to be crucial in explaining the persistence of portage cities a century or more after obsolescence. Many factors that might be considered sunk, or at least fixed for a long period of time, are also likely to depreciate and require replacement over the long time horizon (centuries) that we consider. (Refer again to the discussion in section 4.3.)

A final issue related to mapping our dynamic results to a static model is that prices are changing in the economy over our sample period. In particular, changes in technologies or preferences that affect the value of various natural features or the disutility from crowdedness are likely to change the shapes of the indirect utility curves in Figure 9. Note however that economy-wide changes that do not affect relative utility levels across locations will not change the basic predictions of the model. Improvements in transportation and sanitation technology have reduced disutility from crowdedness. But such a change would flatten the indirect utility curves for all locations, allowing for denser cities across the economy but not necessarily changing rankings of locations.

\subsection{Interpreting earlier evidence}

In considering the spatial organization of economic activity, some early studies attempted to find agglomeration economies in the residual - that is, by correlating productivity with measures of endowments, and noting that the spatial distribution of natural advantages is highly correlated with the location of production. Examples of this approach are Kim (1999) and Ellison and Glaeser (1999). These papers also (correctly) note the fundamental problem that there are easily more potential natural advantages than data points. Our study suggests that economic activity can be spatially correlated even with the location of obsolete endowments. Therefore, Rybczynski-like regression coefficients may conflate the effects of both agglomeration economies (with path dependence) and natural features on productivity.

The work of Davis and Weinstein $(2002,2008)$, showing that the "shock" of Allied bombing during World War II failed to change the equilibrium location of economic activity across Japanese cities, suggests that multiple equilibria and path dependence may not be empirically relevant. Our

\footnotetext{
${ }^{28}$ In Redding, Sturm, and Wolf (2010), sunk costs are explicitly considered in a model of industry location. Without sunk costs, economic activity reallocates across locations instantaneously.
} 
model indicates one reason why postwar Japan might not be an ideal experiment to test for the presence of increasing returns. As noted earlier, heterogeneity in natural features can suppress alternative potential equilibria (see Figure 9, panel B). The rugged topography of much of Japan suggests that there is large variation in the natural productivity value of locations, perhaps enough to preclude the possibility that there exist multiple spatial equilibria.

As a parallel thought experiment that might be more familiar to the North-American reader, consider California, another Ring-of-Fire area with varied topography. Within California, there is large variation in natural features: mountains, deserts, arid valleys with productive soil, oil and mineral deposits, natural harbors, temperate weather, and views of the Pacific. If an experimenter were to remove all reproducible factors from the state and replay history, it seems likely that population would concentrate near the very same fixed factors, in the same locations we see today: in the sunny valleys of Southern California, near the port of San Francisco, in the Sacramento River delta, ${ }^{29}$ and in the fertile Central Valley. In contrast, this need not be the case in a more homogeneous landscape.

\subsection{Extensions and speculations}

The portage phenomenon that we identify here is hardly unique to the sample that we used for this study. Throughout the rest of North America, there are examples of places where obstacles to pre-1900 navigation give rise to trading and transshipment and where these sites continue to be populated places today. The example of Sacramento, at the head of navigation of the Sacramento River during the Gold Rush, was identified above. Albany, New York, is another example of a site that formed around the head of navigation of the Hudson River. This site later became the junction of the Erie and Champlain canals, providing access to the Great Lakes and the St. Lawrence River. Montréal, Quebec, arose as a settlement because it was at the head of navigation of the St. Lawrence River, although today the river has been improved for navigation all the way up to the Great Lakes. (By 1825, the Lachine Rapids were bypassed by a canal that also provided water power to industry later in the century. And Montréal had already become a hub in the railway network, leading it to be the main seaport of eastern Canada.) Edmonton, Alberta, is located on the end of the portage from the Athabasca River to the North Saskatchewan River, which was used by the Hudson Bay Company on its transcontinental route in the 19th century. Ithaca, New York,

\footnotetext{
${ }^{29}$ Although Sacramento's place at the head of navigation on the Sacramento River, as well as its role in transshipment during the California Gold Rush, is noteworthy.
} 
grew up around transshipment. The city is located at the southern tip of Lake Cayuga, which was connected from there to the Susquehanna River by a portage railway in the 1800 s. Water power was later used at the site, which supported a small manufacturing sector. But what made population at this site persist was that it re-specialized in tertiary education. Various other sites in North America began as centers of small-scale manufacturing because of access to water power. Numerous mill towns in New England are such examples, with Lowell, Massachusetts, being perhaps the leading case. These areas persist today, in spite of water power being essentially obsolete in this area. Similar examples abound in the Piedmont of the South, where water power was used in early industrialization.

Examples of related phenomena are found outside North America. We discuss a few examples here. Perhaps the closest parallel between the North American portages of voyageurs is found in Russia, where the Vikings used convenient portages between the watersheds of the Baltic and Black seas. Indeed, many place-names in that area incorporate the word "volok," whose etymology is derived from Slavic words meaning "drag" or "haul." One example is the city of Volokolamsk, which arose at a portage (that is, a volok) between the Lama and Voloshnya rivers, which then flow downstream to Novgorod and Moscow, respectively. Another example is Corinth, Greece, which lies on an isthmus connecting the Peloponnesus to the rest of Greece. The portage at Corinth was convenient relative to rounding the entire Peloponnesus, and Corinth was involved in transshipment and trading beginning in ancient times. This locational advantage was rendered obsolete both with the construction of the Corinth Canal circa 1890 and the expanding size of ships with the Age of Steam. Yet Corinth persists as a populated area to this day, in spite of the old city having been destroyed by earthquakes twice in the 19th century. (See Sherratt, 2006, for more discussion of these and other historical portage sites.) Back in the Americas, Honda is a city at the head of navigation of the lower Magdalena River in Colombia. It grew considerably in the 19th century as a point of transshipment between the steamboats from Barranquilla and the mules headed up the Andes to Bogota. The city persists today, in spite of its locational advantage being made obsolete by a long portage railway (from Beltran to La Dorada), which came into service circa 1910 (Guzmán, 2002).

The present study has been about obstacles to navigation, but we note briefly the case of fords, a symmetric phenomenon when water interrupts movement across land. Fords are places where a river is amenable to crossing on foot (human or animal) or on wheels. Like a portage, this is a natural solution to the coordination problem of where to bring together activity. Indeed, there are 
many examples of places that grew up around the fords of rivers. Rockford, Illinois, is sited at a (former) ford across the Rock River. An example perhaps more familiar to academics, the city of Oxford in England grew up around a ford on the Thames. Further, in German and Dutch, the suffixes -furt and -voorde typically indicate that the populated area owes its original settlement to the presence of a ford; Frankfurt, Germany, is such an example. The natural advantage associated with the ford has very likely dissipated over time. Very little traffic in developed countries actually moves across the river in this manner, and the advantage of constructing a modern bridge at such a point versus elsewhere on the river is uncertain (fords tend to be shallower, but wider, e.g.). Further, such a location would be an absolute disadvantage for operating a ferry, which was another common means of river crossings historically. (It should be noted that some of these fords were probably also portages.)

\section{Conclusion}

We study the evolution of economic activity at pre-19th century portage sites across the U.S. South, Mid-Atlantic, and Midwest. Many of these sites became centers of commerce and manufacturing before 1900, although their natural advantage was made obsolete a century (or more) ago by changes in technology. Nevertheless, these portage sites are likely to be population centers even today. Further, we do not find evidence that these areas have declined since the obsolescence of their portage-related advantages. These results stand in contrast with the predictions of a neoclassical model with local returns to scale that are decreasing or even weakly increasing (but not enough to overcome congestion costs).

Our preferred interpretation for these results is seen in a model with strong increasing returns to scale in local economic activity. The model predicts the possibility of multiple equilibria in population at a given site. We argue that portage acted as a coordination device, selecting which equilibrium would be obtained at that site. Portage shifted out the demand for labor at these sites historically, and it was the historical presence of reproducible factors that selected portage sites for a high-population equilibrium. This is the sense in which our results exhibit path dependence. Some readers might have a preferred reproducible factor, $X$, that they would propose as a parsimonious explanation for these results, where the $X$-factor might be railroads, housing, or some other long-lived asset. But a direct, non-neglible effect today of some early $X$-factor seems unlikely, for a variety of reasons detailed above. Instead, we suggest early factor density had an indirect effect 
via more than a century of overlapping generations of location decisions for various reproducible factors, combined with strong increasing returns to scale locally. In the model, both of these elements are required for persistence: (i) absent the historical density, it might be impossible for factors to coordinate on that location; and (ii) absent increasing returns, there would be no reason for continual increases in factor density following obsolescence of portage.

We have intentionally said little about the welfare implications of these results, although understanding the optimal size and distribution of cities is of paramount interest. The presence of externalities in our model suggests a role for corrective action, in the spirit of Pigou, but further analysis is needed. Further, a perennial concern in models with path dependence is that we might get locked in to a choice that is somehow sub-optimal in the future. (Paul David's case of the QWERTY keyboard is a canonical, albeit controversial example.) However, we have chosen comparison sites that were similar to portage to facilitate the analysis. Thus, it is unlikely that, for example, if we were to magically move Richmond up or down the river, or along the fall line, it would result in substantial welfare gains. One possible exception is Chicago, which would seem to be located $30+$ miles to the northwest of an optimally sited transshipment hub. That said, Chicago's economy is no longer as centered on transshipment, and therefore the percentage cost of its mis-location might be small.

We suggest several avenues for future investigation about the portage phenomenon and about agglomeration in general. First, we do not attempt to distinguish between alternative mechanisms that might generate agglomeration economies in this case, although doing so might be informative. Second, further analysis of the role played by different industries in agglomeration and persistence would be interesting. Portage sites tended to specialize early in commerce and, to a lesser extent, manufacturing. This contrasts with the many ghost towns left behind after mining bonanzas. Third, central to the persistence of population at portages is that these areas were able to re-specialize into other activities. It would be useful to understand what natural endowments or institutions were necessary to make this transformation possible.

\section{References}

Arthur, W. B. (1994). Increasing returns and path dependence in the economy, Ann Arbor: University of Michigan Press.

Atack, J., F. Bateman, M. R. Haines, and R. A. Margo (2009). “Did railroads induce or follow 
economic growth? Urbanization and population growth in the American Midwest, 1850-60." NBER working paper no. 14640.

Bester, C. A., T. G. Conley, and C. B. Hansen (2009). "Inference with Dependent Data Using Cluster Covariance Estimators." Manuscript, University of Chicago Booth School of Business, Chicago.

Cain, L. P. (1985). "William Dean's Theory of Urban Growth: Chicago's Commerce and Industry, 1854-1871.” The Journal of Economic History. June 45 (2), 241-249.

Cashin, E. J. (1986). Colonial Augusta : 'Key of the Indian Countrey', Macon, Ga.: Mercer University Press.

Chandler, A. D. (1972). "Anthracite coal and the beginnings of the industrial revolution in the United States." The Business History Review. Summer 46 (2), 141-181.

Chatterjee, S. (2006). "A quantitative assessment of the role of agglomeration economies in the spatial concentration of U.S. employment." Federal Reserve Bank of Philadelphia Working Paper 06-20.

Ciccone, A. and R. E. Hall (1996). "Productivity and the density of economic activity." American Economic Review. 86 (1), 54-70.

Conley, T. G. (1999). “GMM Estimation with Cross Sectional Dependence.” Journal of Econometrics. September 92 (1), 1-45.

Cronon, W. (1991). Nature's Metropolis, W.W. Norton and Company.

Davis, D. and D. Weinstein (2002). "Bones, bombs, and break points: The geography of economic activity." American Economic Review. 92 (5), 1269-1289.

— and (2008). "A search for multiple equilibria in urban industrial structure." Journal of Regional Science. 48 (1), 29-65.

Donaldson, D. (2010). "Railroads of the Raj." Manuscript, MIT.

Duranton, G. and D. Puga (2004). "Micro-foundations of Urban Agglomeration Economies." in J. V. Henderson and J.-F. Thisse, eds., Handbook of Regional and Urban Economics, Vol. 4, Amsterdam: Elsevier, chapter 48, pp. 2063-2117.

Ellison, G. and E. L. Glaeser (1999). "The Geographic Concentration of Industry: Does Natural Advantage Explain Agglomeration?” American Economic Review. 89 (2), 311-316.

Coagglomeration Patterns." American Economic Review. 100 (3), 1195-1213.

Federal Writers' Project, Georgia (1938). Augusta American Guide Series, Augusta, Ga.: Tidwell Printing Supply Co. 
Fogel, R. W. (1964). Railroads and American Economic Growth: Essays in Econometric History, The Johns Hopkins Press.

Fujita, M. and T. Mori (1996). "The role of ports in the making of major cities: Self-agglomeration and hub-effect." Journal of Development Economics. 49, 93-120.

Glaeser, E. L. and J. Gyourko (2005). “Urban Decline and Durable Housing.” Journal of Political Economy. April 113 (2), 345-375.

Gold, R. N. (1954). "Manufacturing structure and pattern of the South Bend-Mishawaka area." Master's thesis, University of Chicago, Chicago, IL.

Guzmán, A. I. (2002). La ciudad del río Honda, Bogotá, Colombia: Unibiblos.

Haines, M. R. and Inter-university Consortium for Political and Social Research (2004). Historical, Demographic, Economic, and Social Data: The United States, 1790-2002, Ann Arbor, MI: Inter-university Consortium for Political and Social Research (ICPSR). Computer file, http://www.icpsr.org [Accessed March 7, 2006].

Havighurst, W. (1970). River to the West; three centuries of the Ohio, New York: Putnam.

Helpman, E. (1998). "The Size of Regions.” in D. Pines, E. Sadka, and Y. Zilcha, eds., Topics in Public Economics, Cambridge: Cambridge University Press, pp. 33-54.

and P. Krugman (1985). Market Structure and Foreign Trade, Cambridge, MA: MIT Press.

Henderson, J. V. (1974). “The sizes and types of cities.” American Economic Review. 64 (4), 640656.

Henry, W. W. (1900). "Richmond on the James." in L. P. Powell, ed., Historic towns of the southern states, American historic towns, New York: G.P. Putnam's sons, chapter 5.

Holmes, T. J. and S. Lee (2009). "Economies of density versus natural advantage: Crop choice on the back forty." NBER working paper no. 14704.

Hornbeck, R. (2009). "The Enduring Impact of the American Dust Bowl: Short and Long-run Adjustments to Environmental Catastrophe.” Manuscript, Harvard University.

Kim, S. (1999). "Regions, resources, and economic geography: Sources of U.S. regional comparative advantage, 1880-1987." Regional Science and Urban Economics. 29, 1-32.

Krugman, P. (1991a). "History versus expectations." Quarterly Journal of Economics. 106 (2), 651-667.

(1991b). "Increasing returns and economic geography." Journal of Political Economy. 99 (3), 483-499. 
(1993a). "First nature, second nature, and metropolitan location." Journal of Regional Science. 33 (2), 129-144.

(1993b). "The hub effect: Or, threeness in international trade." in J. P. Neary, ed., Theory Policy and Dynamics in International Trade: Essays in Honor of Ronald Jones, Cambridge University Press.

Minnesota Population Center (2004). National Historical Geographic Information System: Pre-release Version 0.1, Minneapolis, MN: University of Minnesota. Computer file, http://www.nhgis.org.

National Geophysical Data Center (2003). Version 2 DMSP-OLS Nighttime Lights Time Series, Boulder, Colorado: NOAA. Downloaded February 8, 2006, from http://www.ngdc.noaa.gov/. DMSP data collected by US Air Force Weather Agency.

Paskoff, P. F. (2008). "Measures of War: A Quantitative Examination of the Civil War's Destructiveness in the Confederacy." Civil War History. LIV (1), 35-62.

Phillips, U. B. (1905). “Transportation in the ante-bellum South: An economic analysis.” Quarterly Journal of Economics. 19 (3), 434-451.

Pred, A. (1980). Urban Growth and City-Systems in the United States, 1840-1860, Harvard University Press.

Putnam, J. W. (1918). The Illinois and Michigan Canal : a study in economic history, Vol. X of Chicago Historical Society's collection, Chicago: University of Chicago Press.

Rappaport, J. and J. D. Sachs (2003). “The United States as a coastal nation.” Journal of Economic Growth. 8, 5-46.

Rauch, J. E. (1991). "Comparative advantage, geographic advantage, and the volume of trade." Economic Journal. September 101 (408), 1230-1244.

(1993). "Does history matter only when it matters little? The case of city-industry location.” Quarterly Journal of Economics. August 108 (3), 843-867.

Redding, S. J., D. M. Sturm, and N. Wolf (2010). "History and industry location: Evidence from German airports." Review of Economics and Statistics. forthcoming.

Redfearn, C. L. (2008). "Persistence in urban form: The long-run durability of employment centers in metropolitan areas.” Regional Science and Urban Economics. 39 (2), 224-232.

Rosen, C. M. (1986). The limits of power: Great fires and the process of city growth in America, Cambridge University Press.

Rosenthal, S. S. and W. C. Strange (2004). "Evidence on the Nature and Sources of Agglomeration Economies." in J. V. Henderson and J.-F. Thisse, eds., Handbook of Regional and Urban Economics, Vol. 4, Amsterdam: Elsevier, chapter 49, pp. 2119-2171. 
Rossi-Hansberg, E. and M. L. Wright (2007). "Urban Structure and Growth.” Review of Economic Studies. 74, 597-624.

Ruggles, S., J. T. Alexander, K. Genadek, R. Goeken, M. B. Schroeder, and M. Sobek (2010). Integrated Public Use Microdata Series: Version 5.0 [Machine-readable database], Minneapolis: University of Minnesota.

Semple, E. C. (1903). American History and Its Geographic Conditions, Houghton, Mifflin and Company.

Sherratt, A. (2006). "Portages: a simple but powerful idea in understanding human history." in C. Westerdahl, ed., The significance of portages: proceedings of the first International Conference on the Significance of Portages, Archaeopress Lyngdal, Vest-Agder, Norway October pp. 1-13.

Trescott, P. B. (1958). “The Louisville and Portland Canal Company, 1825-1874.” The Mississippi Valley Historical Review. March 44 (4), 686-708.

U.S. Army Corps of Engineers: Navigation Data Center (2009). Tons Locked by Commodity Group, CY 1993-2009, U.S. Army Corps of Engineers. http://www.ndc.iwr.usace.army.mil/lpms/cy2009comweb.htm, accessed July 7, 2010.

U.S. Department of Interior, Census Office (1885). Tenth census of the United States, 1880., Vol. 16-17 (Water Power), Washington, DC: GPO. Re-published by Norman Ross Publishing, New York, NY, 1991. 


\section{Figure 1: Fall-line cities from Alabama to North Carolina}

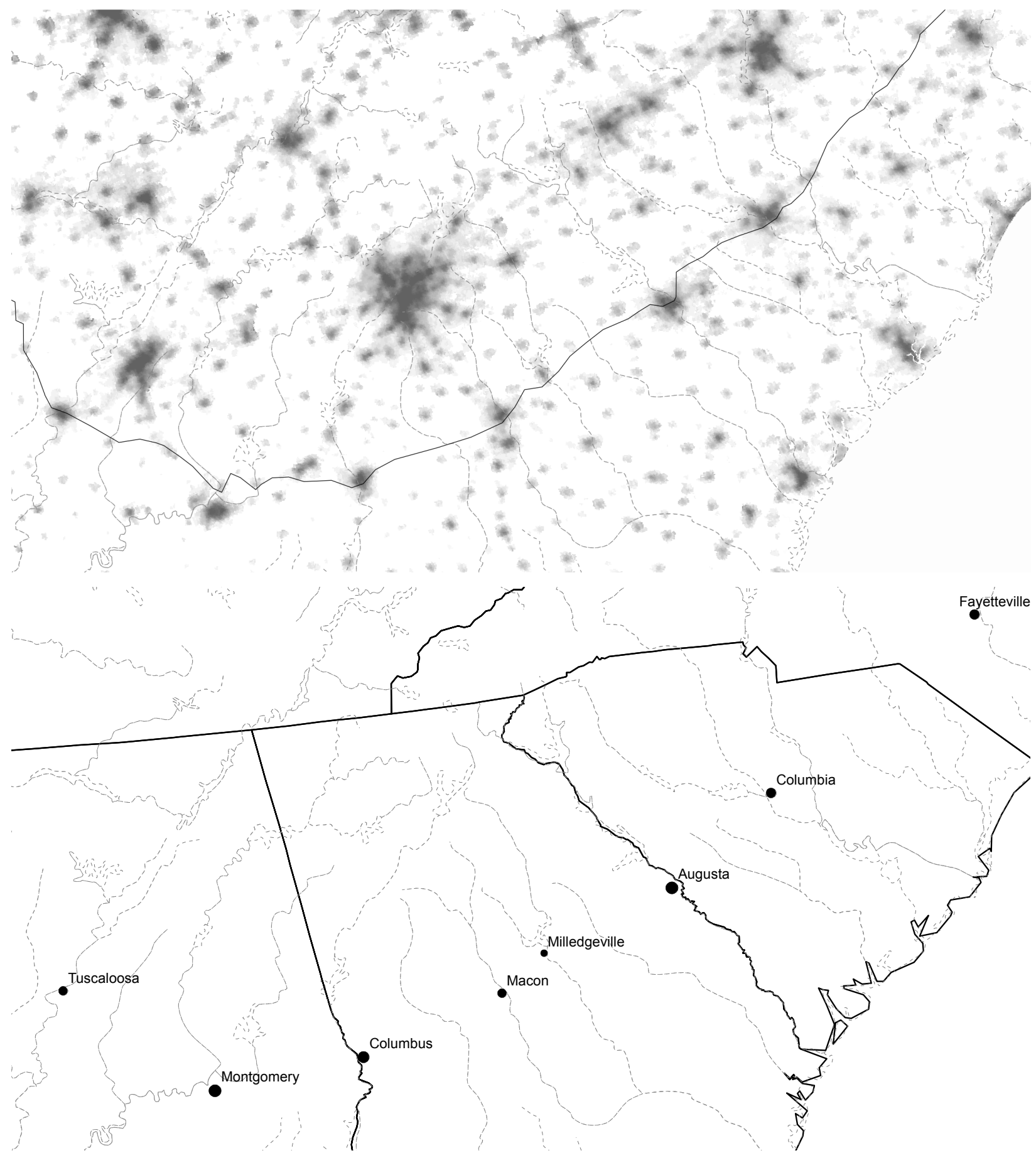

Notes: this map shows the contemporary distribution of economic activity across the southeastern U.S., measured by the 1996-7 nighttime lights layer from NationalAtlas.gov. The nighttime lights are used to present a nearly continuous measure of present-day economic activity at a high spatial frequency. The fall line (solid) is digitized from Physical Divisions of the United States, produced by the U.S. Geological Survey. Major rivers (dashed gray) are from NationalAtlas.gov, based on data produced by the U.S. Geological Survey. Contemporary fall-line cities are labeled in the lower panel. 


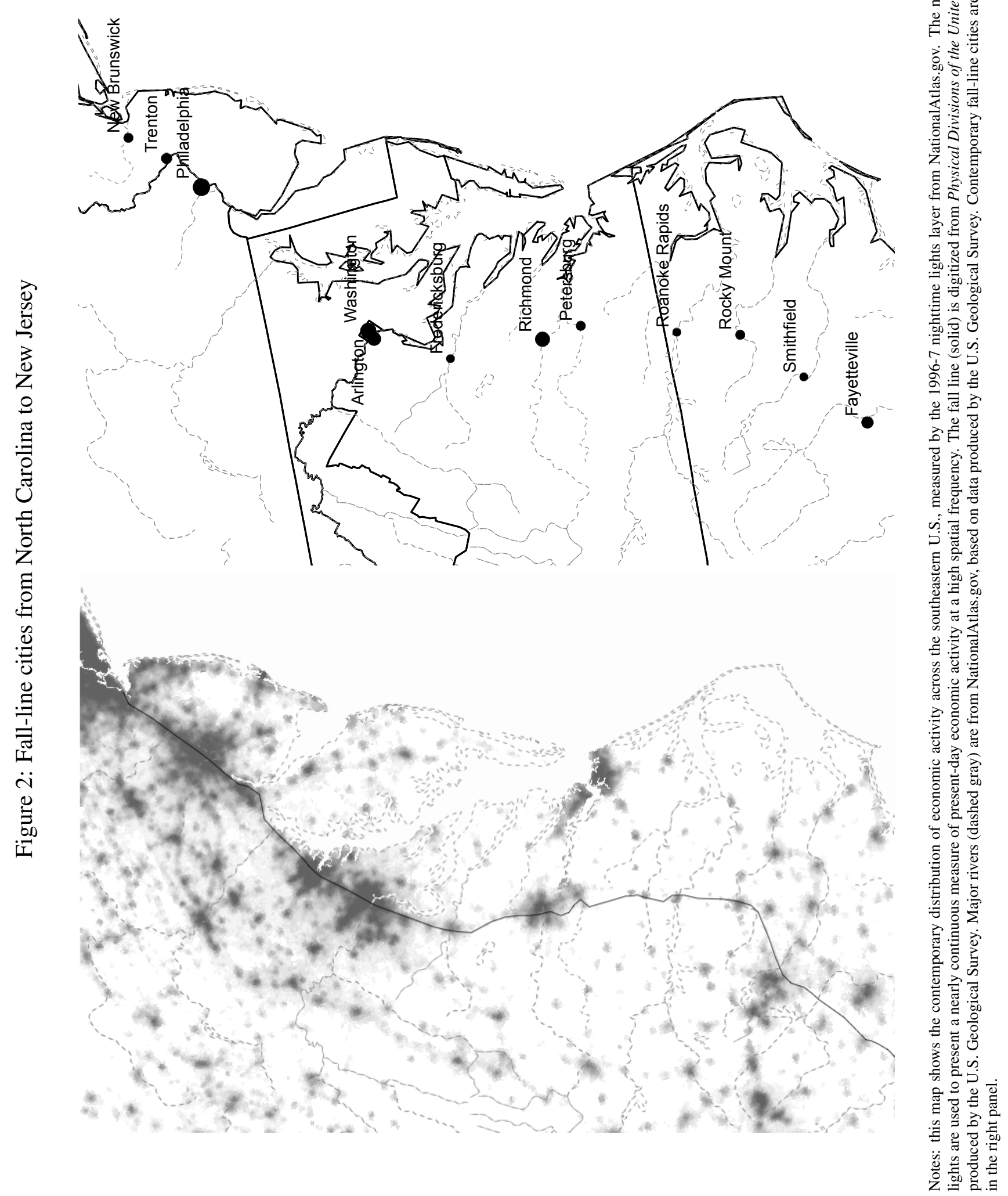


Figure 3: Water-transportation employment across fall-line-area counties, 1850-1930

\section{Panel A. Average share of river's water transportation employment at historical fall-line portage site counties}

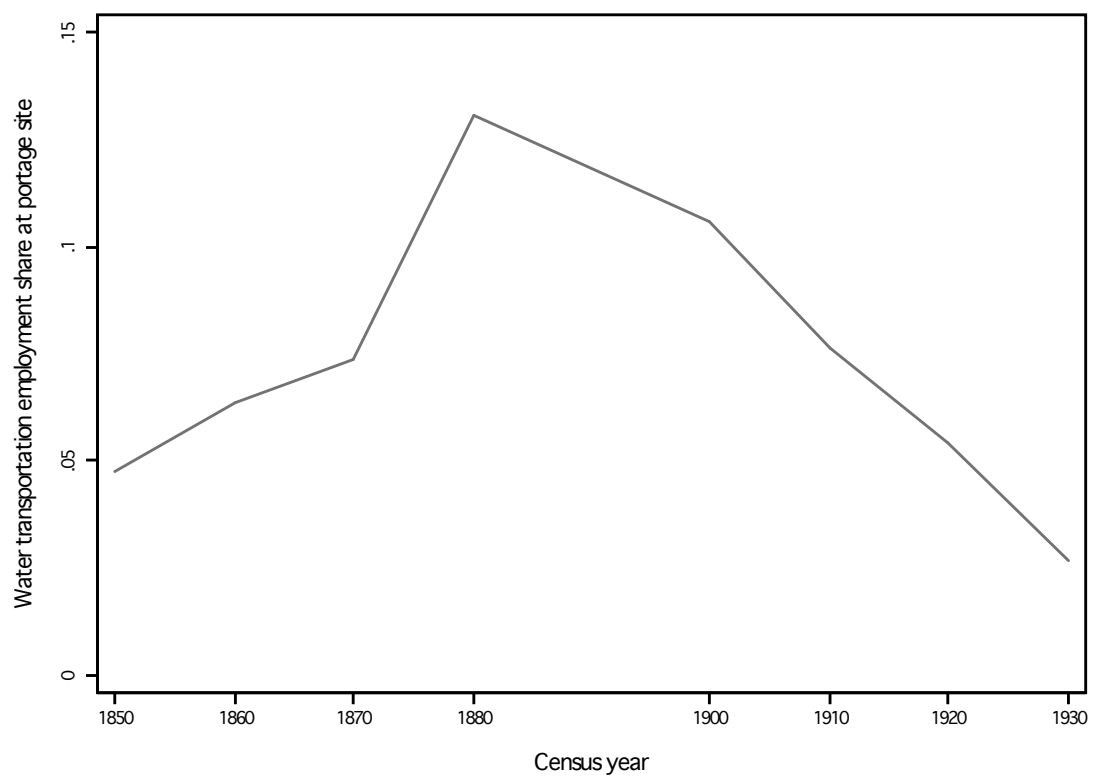

\section{Panel B. Water transportation employment as share of total county employment}

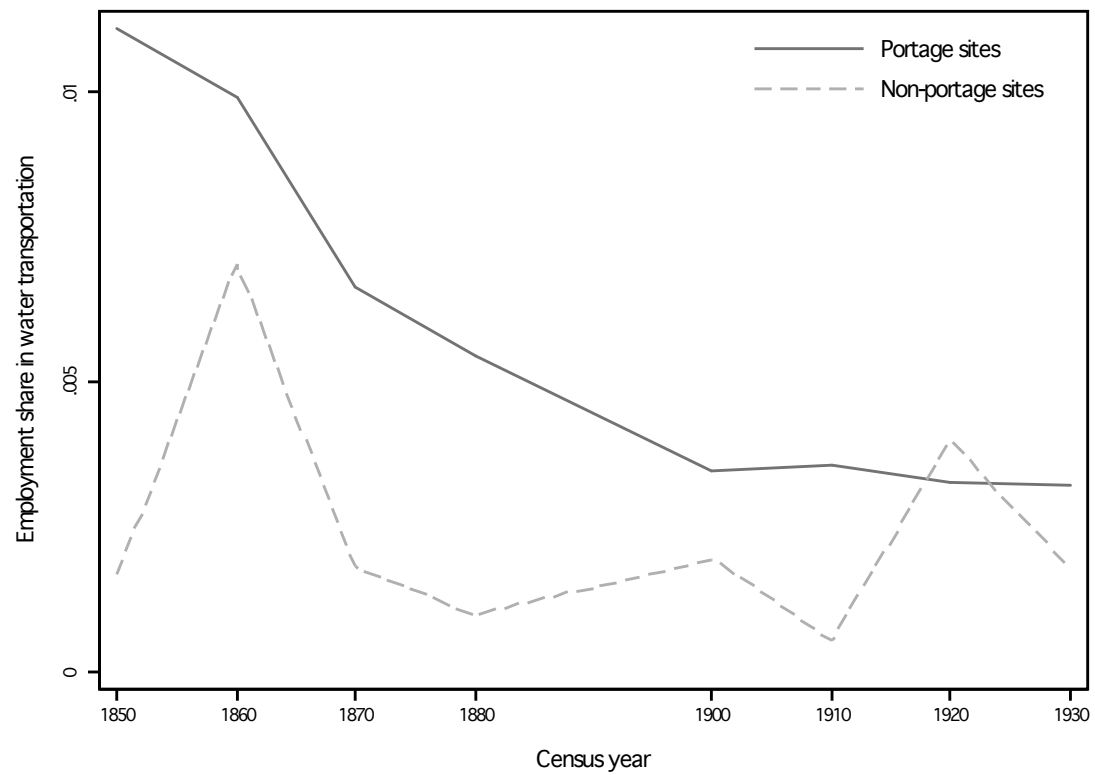

Notes: this figure displays employment in water transportation (e.g., stevedoring occupations) across 51 historical portage sites between 1850 and 1930. We aggregate microdata from 8 IPUMS extracts based on county of residence and water transportation employment in the IPUMS-recoded variable ind1950 $=546$. Two historical portage sites, on the Schuylkill and the Raritan rivers, are excluded due to their continued use as seaports. Panel A shows the average share of water-transportation employment at historical portage sites, out of total water-transportation employment along each river. Panel B shows the average share of water-transportation employment out of total employment, in both portage (solid) and non-portage (dashed) counties adjacent to rivers. 
Figure 4: Population density in 2000 along fall-line rivers

Panel A: Average by absolute distance from the fall line

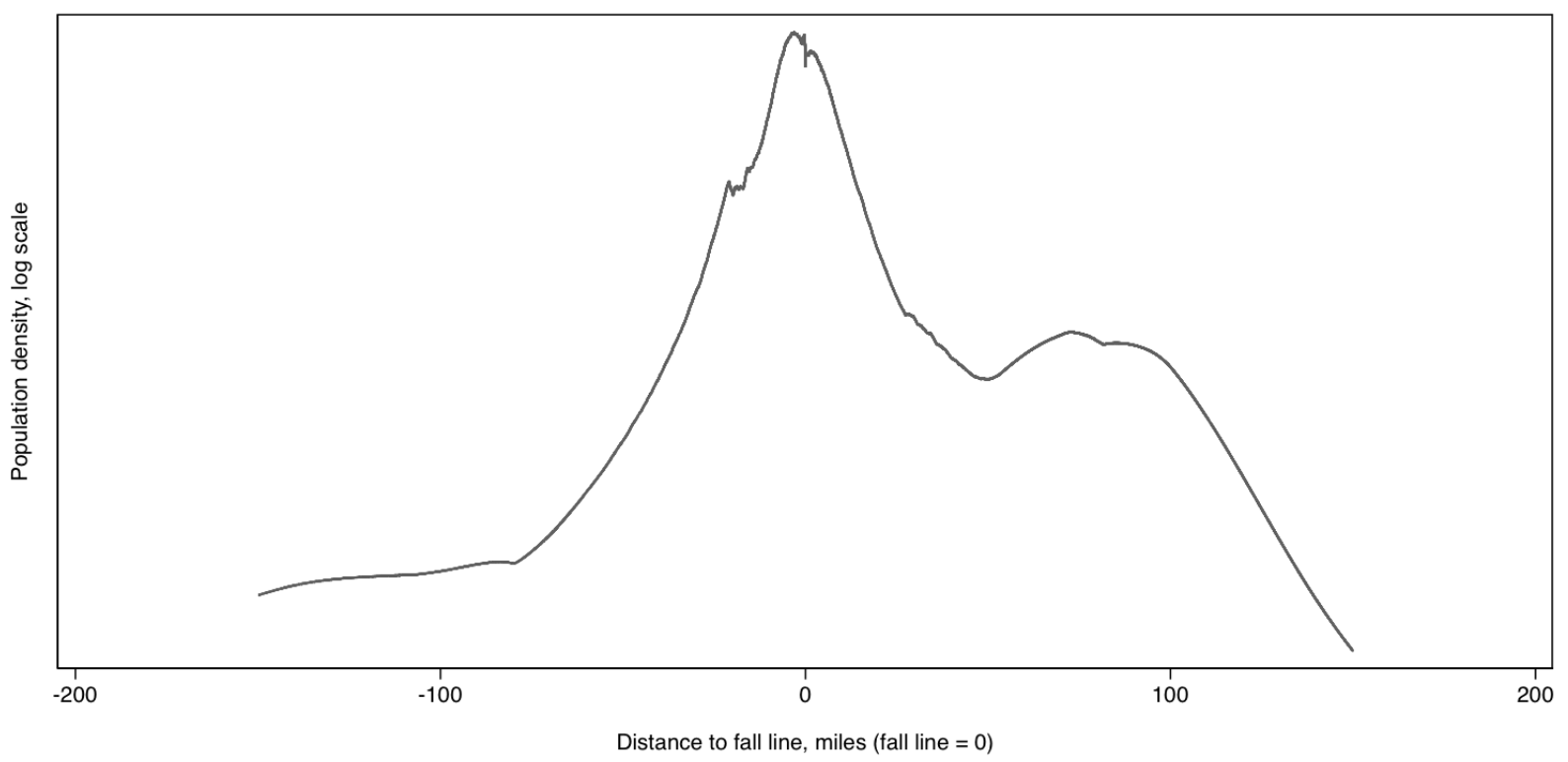

Panel B: Average by renormalized distance from the fall line

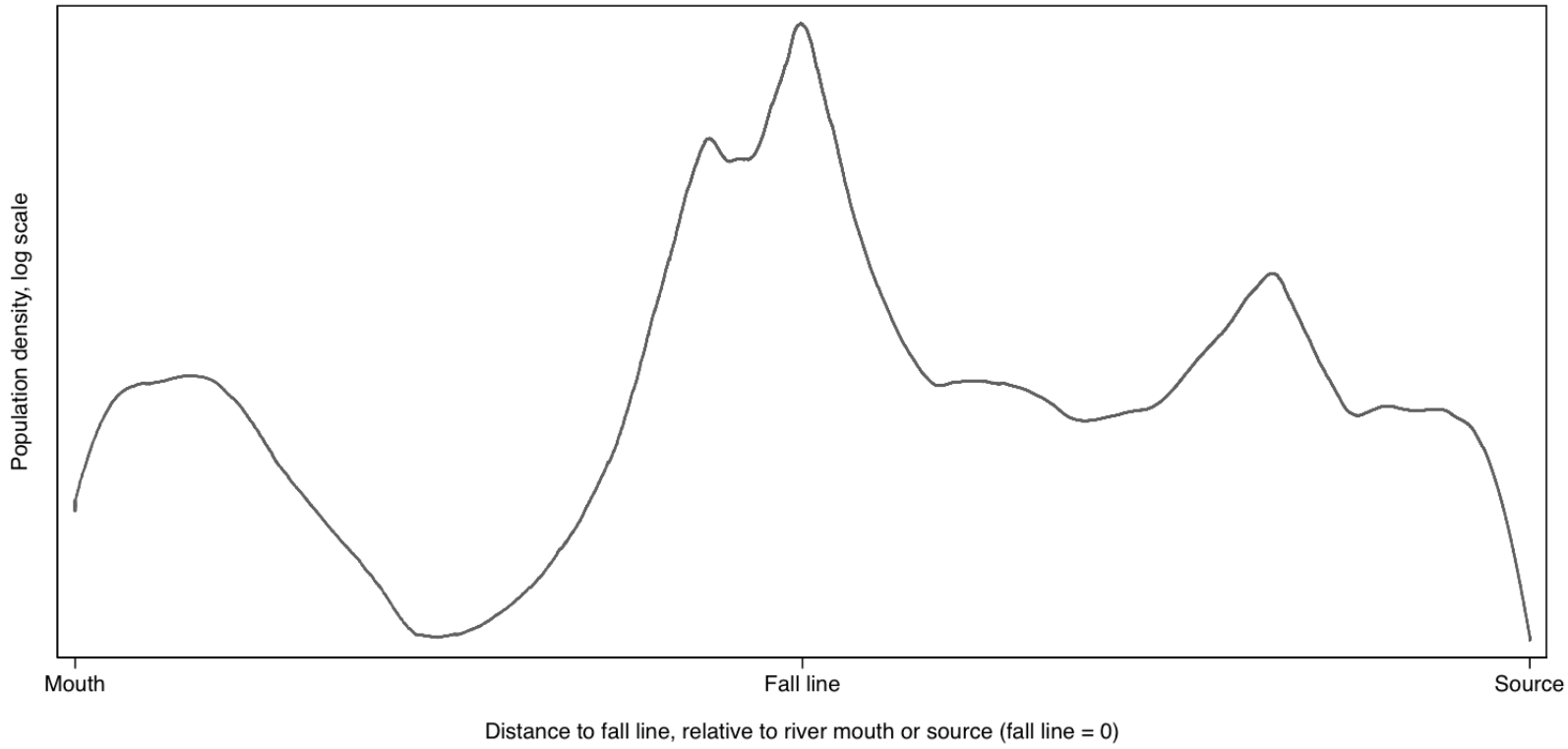

Notes: these graphs display contemporary population density along fall-line rivers. We select census 2000 tracts whose centroids lie within 50 miles along fall-line rivers; the x-axis measures distance to the fall line, where the fall line is normalized to zero, and the Atlantic Ocean lies to the left. In Panel A, these distances are calculated in miles. In Panel B, these distances are normalized for each river relative to the river mouth or the river source. Population density is calculated as the logarithm of population per square mile plus a constant (for display purposes). The raw population data are then smoothed via Stata's lowess procedure, with bandwidths of 0.3 (Panel A) or 0.1 (Panel B). Population density is calculated as the logarithm of population per square mile plus a constant (for display purposes). 
Figure 5: The density of economic activity near early Great Lakes portage routes

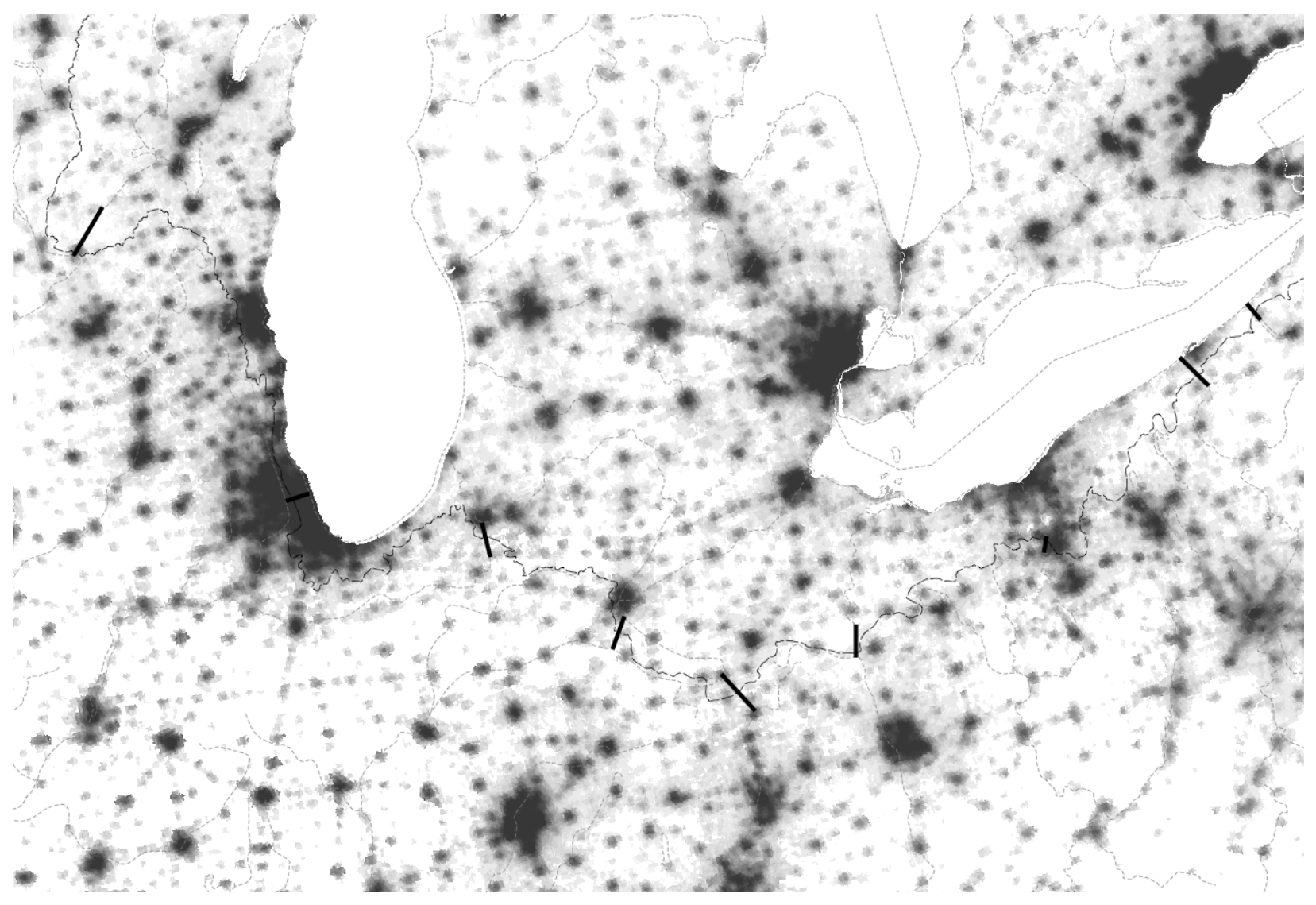

Notes: this map shows the contemporary distribution of economic activity near the Great Lakes, measured by the 1996-7 nighttime lights layer from NationalAtlas.gov. The nighttime lights are used to present a continuous measure of present-day economic activity at a high spatial frequency. The watershed divide (dashed black) and rivers (dashed gray) are from NationalAtlas.gov, based on data produced by the U.S. Geological Survey. The nighttime lights data are used to present a continuous measure of economic activity. Seventeenth-century portage routes between the Great Lakes and the Mississippi River watershed (solid black) are from Semple (1903). Three portage routes in northwestern Wisconsin and northern Minnesota are not shown. Many portage routes lie in present-day metropolitan areas, including (from the northeast) Erie, Akron, Fort Wayne, South Bend, Chicago, and Portage, Wisconsin. Semple notes that portaging was common throughout the area between present-day Milwaukee and Chicago. Here, only the portage route between the Chicago and Illinois Rivers is shown. Many present-day metropolitan areas are located at the Great Lakes mouths of these portage routes, including Cleveland (on the Cuyahoga River), Toledo (the Maumee), St. Joseph, Michigan (the St. Joseph), and Green Bay (the Fox). 
Figure 6: The density of economic activity near portage sites along Mississippi River tributaries

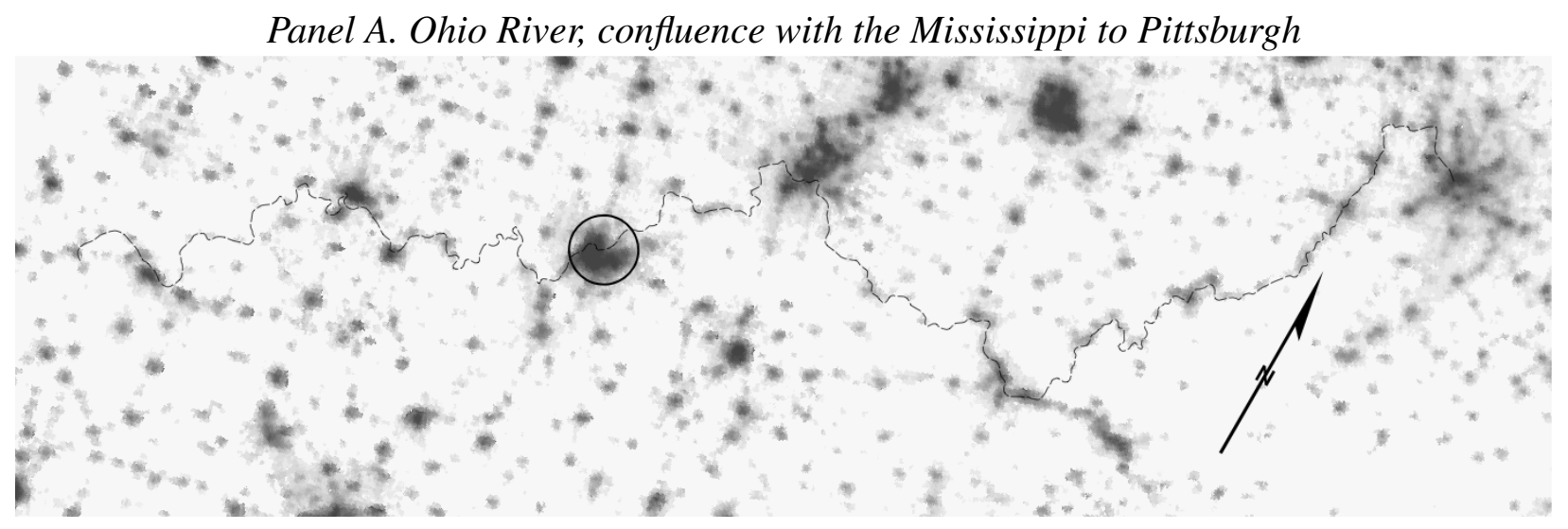

Panel B. Upper Mississippi River, origin to confluence with the Ohio

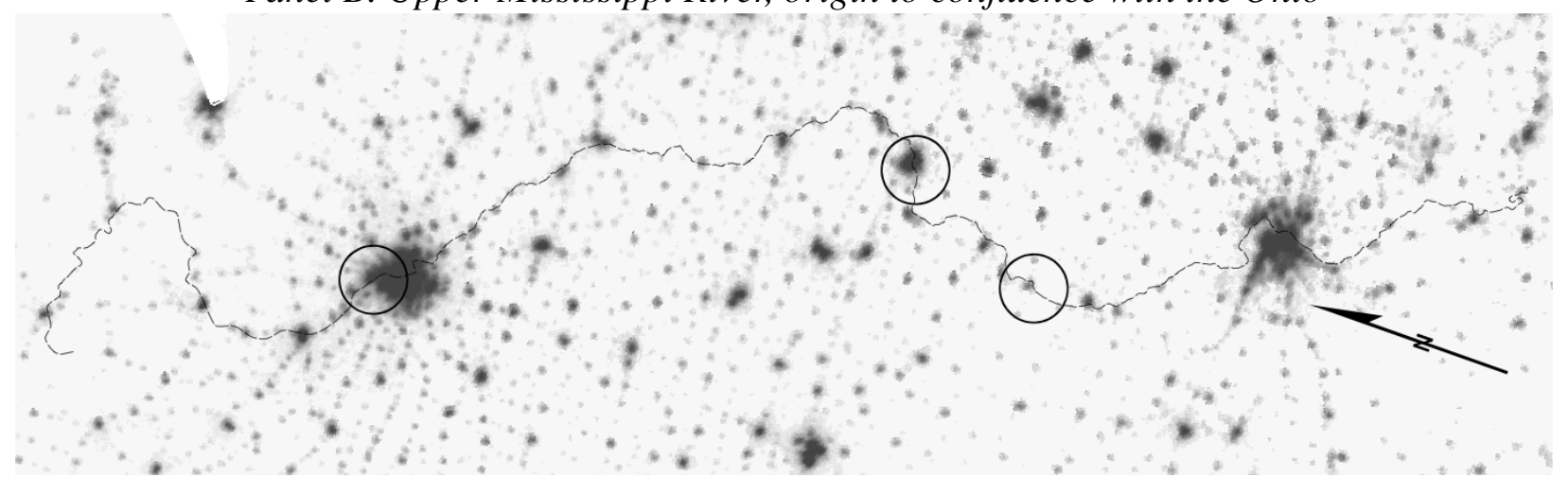

Panel C. Missouri River, origin to confluence with the Mississippi

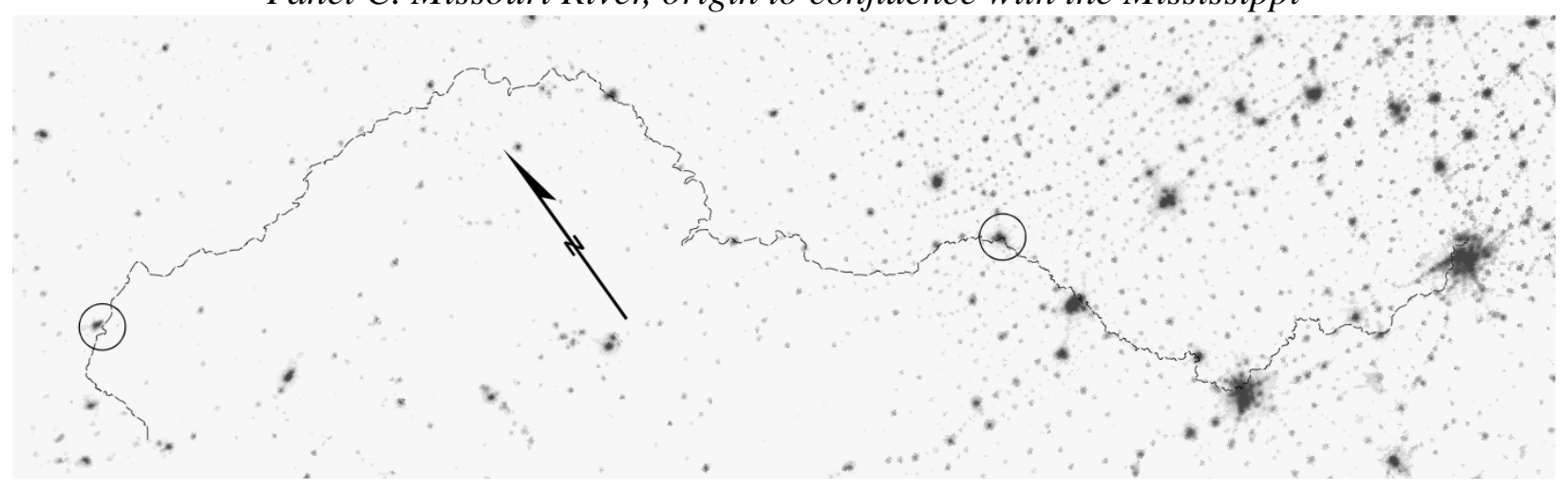

Notes: These maps show the contemporary distribution of economic activity around the major Mississippi River tributaries, as measured by the NationalAtlas.gov nighttime lights layer. The maps have been individually re-oriented and re-scaled for display purposes. Rivers (solid white) are from NationalAtlas.gov, based on data produced by the U.S. Geological Survey. The nighttime lights data are used to present a continuous measure of economic activity. Likely 19th-century portage sites (large circles) are collected from 19th-century U.S. Army Corps of Engineers Surveys. Shown near the center of Panel A are the falls of the Ohio near Louisville, Kentucky. Shown in Panel B are (from left) the Saint Anthony Falls near Minneapolis, the Rock Island Rapids near the Quad Cities (center), and the Des Moines Rapids near Keokuk, Iowa. Shown in Panel C are (from left) the Great Falls of the Missouri River near Great Falls, Montana, and the early head of steamboat navigation at Sioux City, Iowa (center). Confluences with other rivers (small dots) are from NationalAtlas.gov. 
Figure 7: Relative population density across fall-line-area counties, 1790-2000

Panel A. With respect to distance to historical portage sites

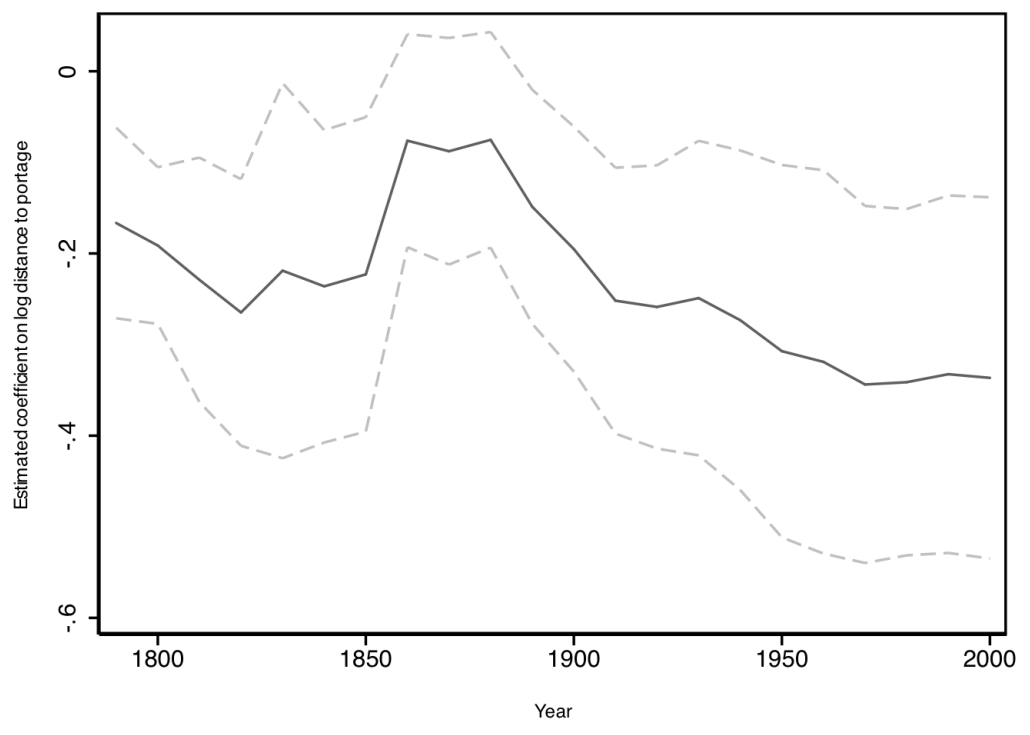

Panel B. With respect to watershed area upstream from portage site

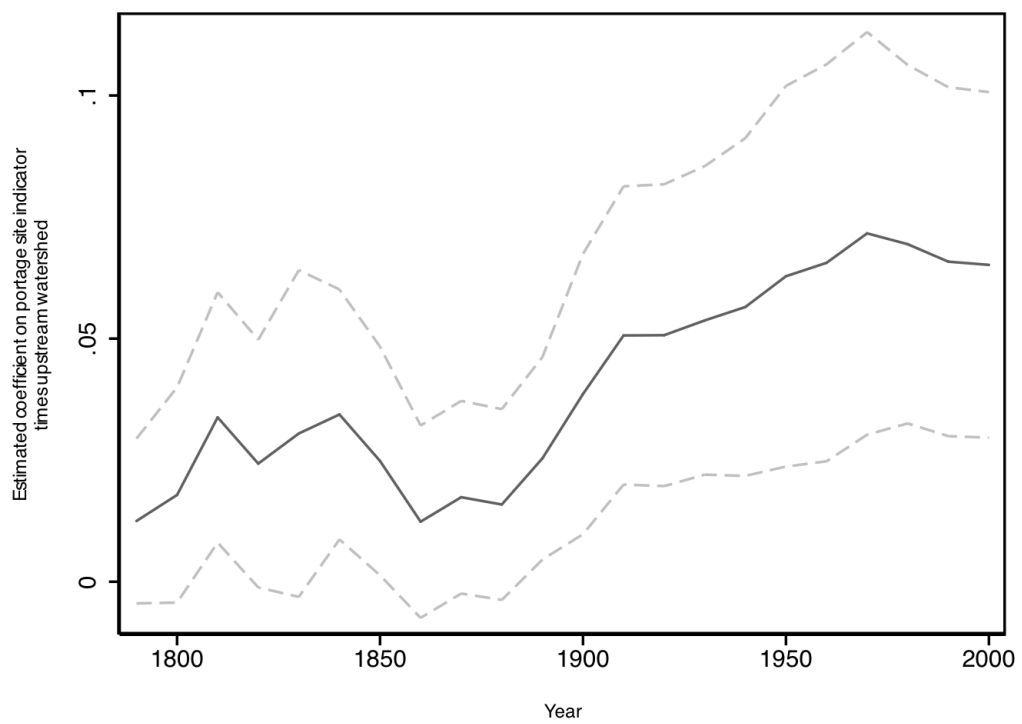

Notes: these graphs display estimates of equations (1) and (2) in the text. Coefficient estimates are from regressions estimated separately by decade of the natural log of county-year population density on the natural log of distance from the nearest river/fall-line intersection to the centroid of the county (Panel A), or on the interaction of portage site with the log of land area in the watershed upstream of the fall line, a variable that proxies for demand for commerce at the portage site (Panel B). The basic specification also includes a fourth-order polynomial in latitude and longitude and a set of fixed effects for watersheds of each river that crosses the fall line. The sample includes counties whose centroids lie within 150 miles of fall-line rivers. 
Figure 8: Population density and portage in the Midwest, 1800-2000

Panel A. Distance to historical portage sites across Great-Lakes watershed divide, 1820-2000

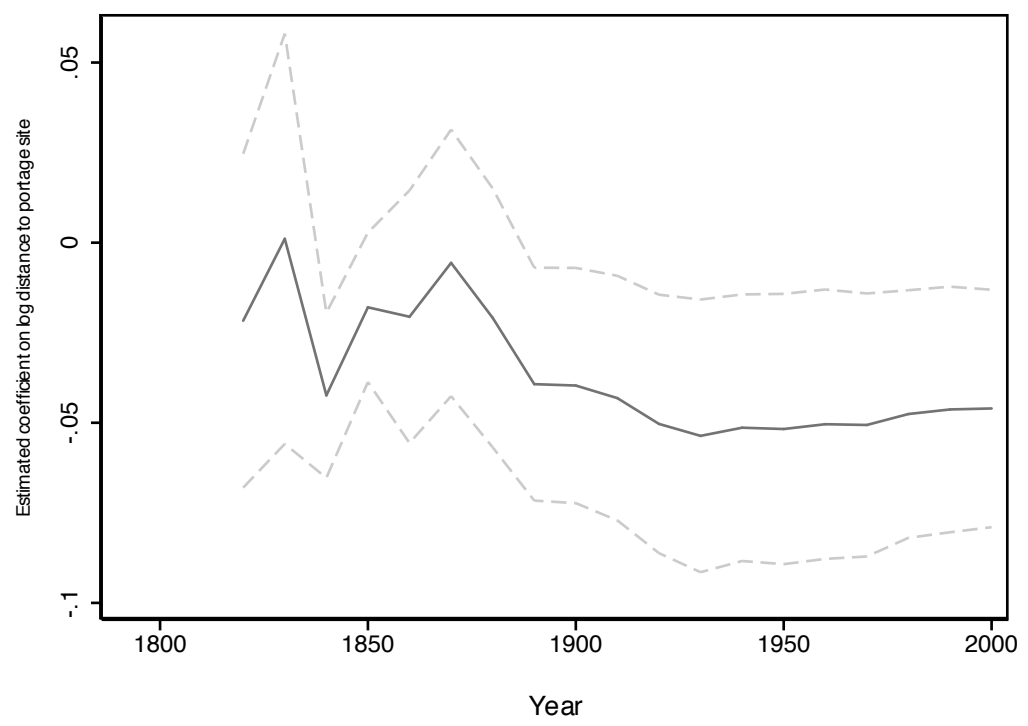

Panel B: Distance to the falls along the Mississippi, Ohio, and Missouri Rivers, 1800-2000

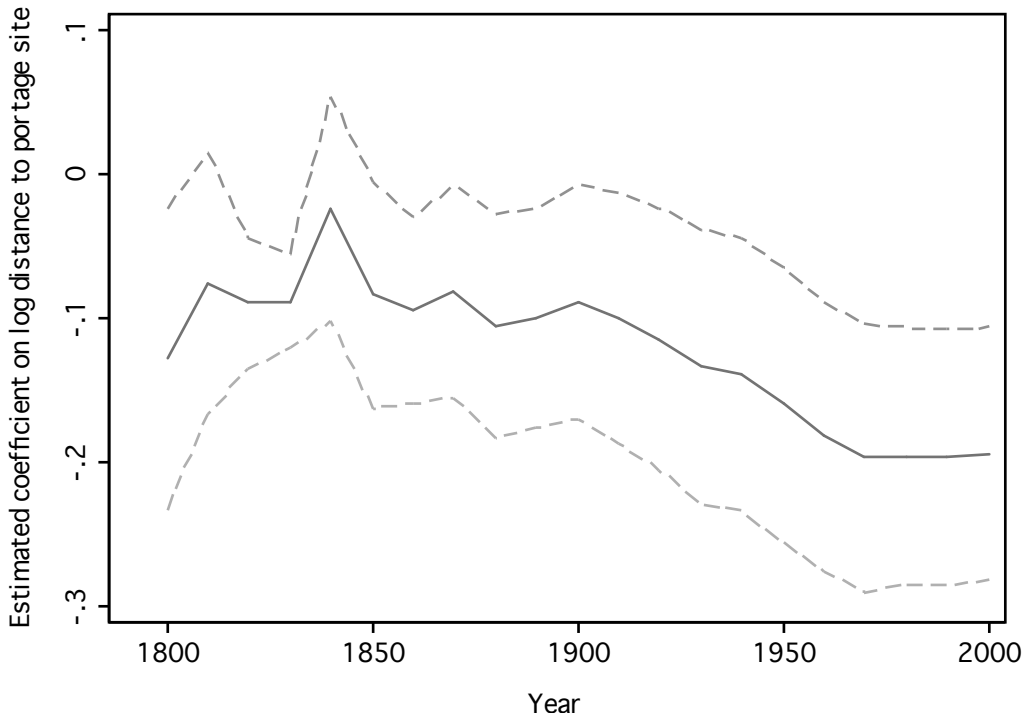

Notes: These graphs show coefficient estimates from regressions estimated separately by decade of county-year log population density on log distance to historical portage sites (Panel A) or falls (Panel B). For Panel A, the sample is all counties that lie within 12.5 miles of the Great LakesMississippi River watershed divide. For Panel B, the sample is all counties that lie within 12.5 miles of the Upper Mississippi, Ohio, and Missouri rivers. Specifications and data sources are similar to those reported for fall-line-area counties reported in Table 1, column (4). 
Figure 9: Equilibrium density in a model with natural advantages and increasing returns

\section{Panel A: Unique equilibrium with natural advantages and strong congestion costs}

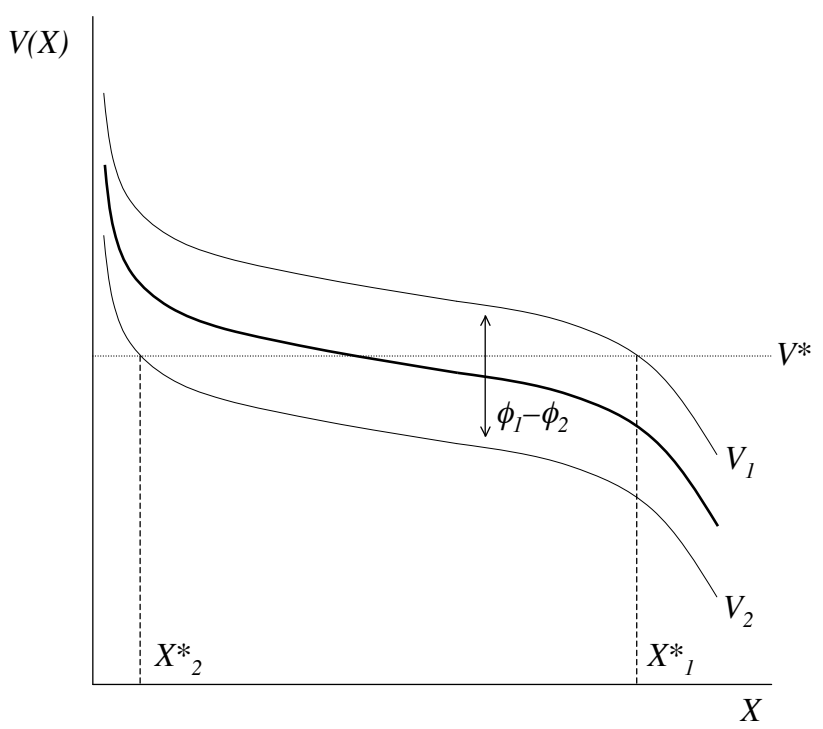

Panel B: Multiple equilibria (or not) with strong increasing returns

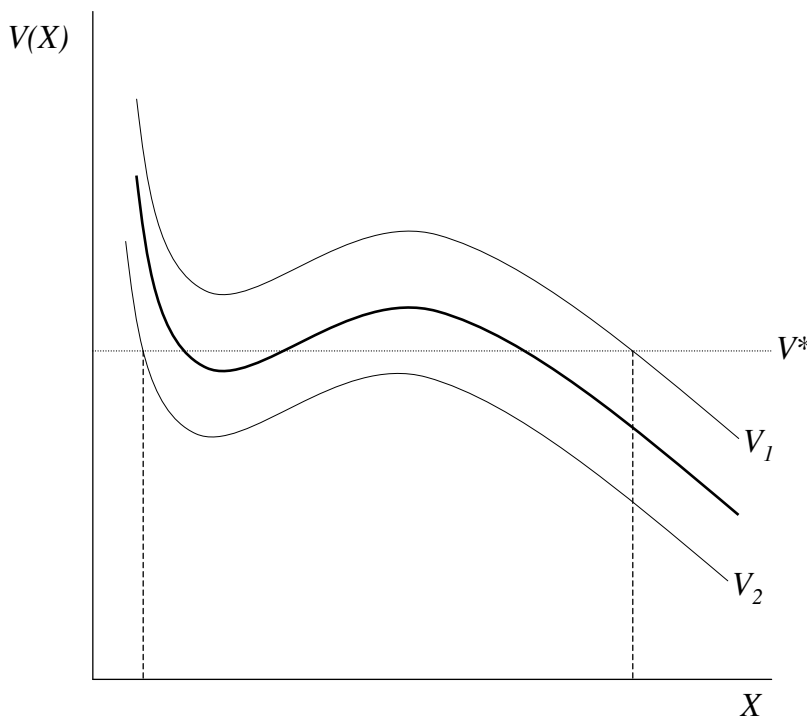

Notes: These graphs show the determination of equilibrium in the model from section 6. Curved lines represent the indirect utility $V$ as a function of factor density $X$ in a particular location $g$. The horizontal (dotted) line shows the equilibrium utility level $V^{*}$ achieved in other locations in the economy. Equilibrium at location $g$ obtains when indirect utility equals $V^{*}$, i.e., when the $V_{g}$ curve intersects the dotted line. The units of the axes are natural logarithms. Panel A corresponds to Case (i) in the text, in which agglomeration effects are too weak to overcome congestion costs for all $X$. In this case, the equilibrium at a given site is unique, and natural advantages $(\phi)$ fully determine factor densities across sites. Panel B corresponds to Case (ii) in the text, in which, for some intermediate range of $X$, returns to scale increase faster than congestion costs. (This range corresponds to the part of the curve that slopes up with $X$.) The possibility of multiple equilibria is shown by the middle curve (thick black line), which intersects $V^{*}$ at more than one point. (Only the left and right intersections are stable equilibria, however.) In spite of the presence of strong increasing returns, equilibrium is fully determined in locations 1 and 2, because of differences in natural advantages, which shift the $V$ curves. 


\begin{tabular}{|c|c|c|c|c|c|c|c|c|c|c|c|c|c|c|}
\hline \multirow[b]{3}{*}{ Specifications: } & (1) & (2) & (3) & (4) & (5) & (6) & (7) & (8) & (9) & (10) & (11) & (12) & (13) & (14) \\
\hline & Basic & \multicolumn{2}{|c|}{ Other Spatial Controls } & \multicolumn{3}{|c|}{ Additional Fixed Factors } & \multicolumn{4}{|c|}{ Alternative Samples } & \multicolumn{4}{|c|}{ Alternative Estimators } \\
\hline & & $\begin{array}{l}\text { State } \\
\text { fixed } \\
\text { effects }\end{array}$ & $\begin{array}{l}\text { Distance } \\
\text { from } \\
\text { various } \\
\text { features }\end{array}$ & $\begin{array}{l}\text { Climate } \\
\text { variables }\end{array}$ & $\begin{array}{l}\text { Aquifer } \\
\text { Share }\end{array}$ & $\begin{array}{l}\text { Mean } \\
\text { elevation }\end{array}$ & $\begin{array}{l}\text { East of } \\
\text { Miss. } \\
\text { River }\end{array}$ & $\begin{array}{l}\text { Atlantic } \\
\text { Rivers } \\
\text { only }\end{array}$ & $\begin{array}{l}\text { Within } \\
5 \mathrm{mi} \text { of } \\
\text { fall line }\end{array}$ & $\begin{array}{l}\text { Within } \\
5 \mathrm{mi} \text { of a } \\
\text { principal } \\
\text { river }\end{array}$ & $\begin{array}{l}\text { Cluster } \\
\text { on State }\end{array}$ & $\begin{array}{l}\text { Cluster } \\
\text { on } 60 \mathrm{~km} \\
\text { grid cells }\end{array}$ & $\begin{array}{l}\text { Boot- } \\
\text { strap on } \\
\text { river }\end{array}$ & $\begin{array}{l}\text { Conley's } \\
\text { estimator } \\
100 \text {-mile } \\
\text { cutoff }\end{array}$ \\
\hline Explanatory variables: & \multicolumn{14}{|c|}{ Panel A: Census Tracts, 2000, $N=21452$} \\
\hline $\begin{array}{l}\text { Distance to portage } \\
\text { site, natural logs }\end{array}$ & $\begin{array}{l}-0.558 \\
(0.099) * * *\end{array}$ & $\begin{array}{l}-0.598 \\
(0.076) * * *\end{array}$ & $\begin{array}{l}-0.733 \\
(0.095)^{* * *}\end{array}$ & $\begin{array}{l}-0.407 \\
(0.093)^{* * *}\end{array}$ & $\begin{array}{l}-0.542 \\
(0.095) * * *\end{array}$ & $\begin{array}{l}-0.481 \\
(0.103)^{* * *}\end{array}$ & $\begin{array}{l}-0.618 \\
(0.125)^{* * *}\end{array}$ & $\begin{array}{l}-0.708 \\
(0.138) * * *\end{array}$ & $\begin{array}{l}-0.651 \\
(0.087)^{* * *}\end{array}$ & $\begin{array}{l}-0.570 \\
(0.095)^{* * *}\end{array}$ & $\begin{array}{l}-0.558 \\
(0.108) * * *\end{array}$ & $\begin{array}{l}-0.558 \\
(0.101) * * *\end{array}$ & $\begin{array}{l}-0.558 \\
(0.119)^{* * *}\end{array}$ & $\begin{array}{l}-0.558 \\
(0.083) * * *\end{array}$ \\
\hline $\begin{array}{l}\text { Centroid within } 15 \mathrm{mi} \\
\text { of portage site }\end{array}$ & $\begin{array}{l}1.204 \\
(0.199)^{* * *}\end{array}$ & $\begin{array}{l}1.144 \\
(0.191)^{* * *}\end{array}$ & $\begin{array}{l}1.270 \\
(0.214)^{* * *}\end{array}$ & $\begin{array}{l}0.994 \\
(0.192) * * *\end{array}$ & $\begin{array}{l}1.143 \\
(0.210) * * *\end{array}$ & $\begin{array}{l}1.050 \\
(0.196) * * *\end{array}$ & $\begin{array}{l}1.119 \\
(0.253) * * *\end{array}$ & $\begin{array}{l}1.161 \\
(0.297)^{* * *}\end{array}$ & $\begin{array}{l}0.761 \\
(0.352) * *\end{array}$ & $\begin{array}{l}1.268 \\
(0.278) * * *\end{array}$ & $\begin{array}{l}1.204 \\
(0.082)^{* * *}\end{array}$ & $\begin{array}{l}1.204 \\
(0.103)^{* * *}\end{array}$ & $\begin{array}{l}1.204 \\
(0.233) * * *\end{array}$ & $\begin{array}{l}1.204 \\
(0.214) * * *\end{array}$ \\
\hline $\begin{array}{l}\text { Any part within } 4 \mathrm{mi} \text { of } \\
\text { portage site }\end{array}$ & $\begin{array}{l}0.977 \\
(0.160)^{* * *}\end{array}$ & $\begin{array}{l}0.845 \\
(0.136) * * *\end{array}$ & $\begin{array}{l}1.109 \\
(0.114) * * *\end{array}$ & $\begin{array}{l}0.737 \\
(0.125)^{* * *}\end{array}$ & $\begin{array}{l}0.993 \\
(0.152)^{* * *}\end{array}$ & $\begin{array}{l}0.790 \\
(0.183)^{* * *}\end{array}$ & $\begin{array}{l}1.046 \\
(0.139)^{* * *}\end{array}$ & $\begin{array}{l}1.156 \\
(0.115)^{* * *}\end{array}$ & $\begin{array}{l}0.512 \\
(0.084)^{* * *}\end{array}$ & $\begin{array}{l}0.911 \\
(0.123)^{* * *}\end{array}$ & $\begin{array}{l}0.977 \\
(0.198) * * *\end{array}$ & $\begin{array}{l}0.977 \\
(0.159) * * *\end{array}$ & $\begin{array}{l}0.977 \\
(0.158) * * *\end{array}$ & $\begin{array}{l}0.977 \\
(0.233)^{* * *}\end{array}$ \\
\hline $\begin{array}{l}\text { Both of previous two } \\
\text { conditions }\end{array}$ & $\begin{array}{l}1.192 \\
(0.168)^{* * *}\end{array}$ & $\begin{array}{l}1.127 \\
(0.163) * * *\end{array}$ & $\begin{array}{l}1.304 \\
(0.197)^{* * *}\end{array}$ & $\begin{array}{l}0.982 \\
(0.166)^{* * *}\end{array}$ & $\begin{array}{l}1.144 \\
(0.179)^{* * *}\end{array}$ & $\begin{array}{l}1.041 \\
(0.170) * * *\end{array}$ & $\begin{array}{l}1.165 \\
(0.185)^{* * *}\end{array}$ & $\begin{array}{l}1.235 \\
(0.211)^{* * *}\end{array}$ & $\begin{array}{l}0.780 \\
(0.216)^{* * *}\end{array}$ & $\begin{array}{l}1.250 \\
(0.227)^{* * *}\end{array}$ & $\begin{array}{l}1.192 \\
(0.079) * * *\end{array}$ & $\begin{array}{l}1.192 \\
(0.081)^{* * *}\end{array}$ & $\begin{array}{l}1.192 \\
(0.164)^{* * *}\end{array}$ & $\begin{array}{l}1.192 \\
(0.151)^{* * *}\end{array}$ \\
\hline $\begin{array}{l}\text { Distance to placebo } \\
\text { site, natural logs }\end{array}$ & $\begin{array}{l}-0.126 \\
(0.173)\end{array}$ & $\begin{array}{l}-0.097 \\
(0.156)\end{array}$ & $\begin{array}{l}-0.253 \\
(0.154)\end{array}$ & $\begin{array}{l}-0.232 \\
(0.134) *\end{array}$ & $\begin{array}{l}-0.083 \\
(0.136)\end{array}$ & $\begin{array}{l}-0.183 \\
(0.164)\end{array}$ & $\begin{array}{c}0.007 \\
(0.117)\end{array}$ & $\begin{array}{c}0.063 \\
(0.178)\end{array}$ & $\begin{array}{l}-2.095 \\
(3.880)\end{array}$ & $\begin{array}{l}-0.138 \\
(0.164)\end{array}$ & $\begin{array}{l}-0.126 \\
(0.207)\end{array}$ & $\begin{array}{l}-0.126 \\
(0.159)\end{array}$ & $\begin{array}{l}-0.126 \\
(0.183)\end{array}$ & $\begin{array}{l}-0.126 \\
(0.103)\end{array}$ \\
\hline \multicolumn{15}{|c|}{ Panel B: Nighttime Lights, 1996-97, N=65000 } \\
\hline $\begin{array}{l}\text { Distance to portage } \\
\text { site, natural logs }\end{array}$ & $\begin{array}{l}-0.248 \\
(0.058) * * *\end{array}$ & $\begin{array}{l}-0.236 \\
(0.053) * * *\end{array}$ & $\begin{array}{l}-0.142 \\
(0.091)\end{array}$ & $\begin{array}{l}-0.241 \\
(0.057)^{* * *}\end{array}$ & $\begin{array}{l}-0.255 \\
(0.058) * * *\end{array}$ & $\begin{array}{l}-0.199 \\
(0.057) * * *\end{array}$ & $\begin{array}{l}-0.190 \\
(0.084) * *\end{array}$ & $\begin{array}{l}-0.237 \\
(0.107) * *\end{array}$ & $\begin{array}{l}-0.278 \\
(0.074) * * *\end{array}$ & $\begin{array}{l}-0.263 \\
(0.055)^{* * *}\end{array}$ & $\begin{array}{l}-0.248 \\
(0.068) * * *\end{array}$ & $\begin{array}{l}-0.248 \\
(0.072) * * *\end{array}$ & $\begin{array}{l}-0.248 \\
(0.055) * * *\end{array}$ & $\begin{array}{l}-0.248 \\
(0.083)^{* * *}\end{array}$ \\
\hline $\begin{array}{l}\text { Centroid within } 15 \mathrm{mi} \\
\text { of portage site }\end{array}$ & $\begin{array}{l}0.786 \\
(0.126)^{* * *}\end{array}$ & $\begin{array}{l}0.726 \\
(0.121)^{* * *}\end{array}$ & $\begin{array}{c}0.492 \\
(0.153)^{* * *}\end{array}$ & $\begin{array}{l}0.761 \\
(0.126)^{* * *}\end{array}$ & $\begin{array}{l}0.790 \\
(0.127)^{* * *}\end{array}$ & $\begin{array}{l}0.732 \\
(0.121)^{* * *}\end{array}$ & $\begin{array}{l}0.533 \\
(0.143)^{* * *}\end{array}$ & $\begin{array}{l}0.590 \\
(0.156)^{* * *}\end{array}$ & $\begin{array}{l}0.334 \\
(0.125) * *\end{array}$ & $\begin{array}{l}0.830 \\
(0.130)^{* * *}\end{array}$ & $\begin{array}{l}0.786 \\
(0.136) * * *\end{array}$ & $\begin{array}{l}0.786 \\
(0.134)^{* * *}\end{array}$ & $\begin{array}{l}0.786 \\
(0.150)^{* * *}\end{array}$ & $\begin{array}{l}0.786 \\
(0.209) * * *\end{array}$ \\
\hline $\begin{array}{l}\text { Any part within } 4 \mathrm{mi} \text { of } \\
\text { portage site }\end{array}$ & $\begin{array}{l}1.156 \\
(0.170)^{* * *}\end{array}$ & $\begin{array}{l}1.058 \\
(0.168) * * *\end{array}$ & $\begin{array}{l}0.507 \\
(0.220)^{* *}\end{array}$ & $\begin{array}{l}1.121 \\
(0.171)^{* * *}\end{array}$ & $\begin{array}{l}1.158 \\
(0.170)^{* * *}\end{array}$ & $\begin{array}{l}1.049 \\
(0.169)^{* * *}\end{array}$ & $\begin{array}{c}0.942 \\
(0.190) * * *\end{array}$ & $\begin{array}{l}0.988 \\
(0.214) * * *\end{array}$ & $\begin{array}{l}0.388 \\
(0.151)^{* *}\end{array}$ & $\begin{array}{l}1.107 \\
(0.166) * * *\end{array}$ & $\begin{array}{l}1.156 \\
(0.179)^{* * *}\end{array}$ & $\begin{array}{l}1.156 \\
(0.087)^{* * *}\end{array}$ & $\begin{array}{l}1.156 \\
(0.172)^{* * *}\end{array}$ & $\begin{array}{c}1.156 \\
(0.383)^{* * *}\end{array}$ \\
\hline $\begin{array}{l}\text { Both of previous two } \\
\text { conditions }\end{array}$ & $\begin{array}{l}0.786 \\
(0.126)^{* * *}\end{array}$ & $\begin{array}{l}0.726 \\
(0.121)^{* * *}\end{array}$ & $\begin{array}{l}0.492 \\
(0.153)^{* * *}\end{array}$ & $\begin{array}{l}0.761 \\
(0.126) * * *\end{array}$ & $\begin{array}{l}0.790 \\
(0.127) * * *\end{array}$ & $\begin{array}{l}0.732 \\
(0.121) * * *\end{array}$ & $\begin{array}{l}0.533 \\
(0.143) * * *\end{array}$ & $\begin{array}{l}0.590 \\
(0.156) * * *\end{array}$ & $\begin{array}{c}0.334 \\
(0.125) * *\end{array}$ & $\begin{array}{l}0.830 \\
(0.130) * * *\end{array}$ & $\begin{array}{l}0.786 \\
(0.136) * * *\end{array}$ & $\begin{array}{l}0.786 \\
(0.134) * * *\end{array}$ & $\begin{array}{l}0.786 \\
(0.142) * * *\end{array}$ & $\begin{array}{l}0.786 \\
(0.209) * * *\end{array}$ \\
\hline $\begin{array}{l}\text { Distance to placebo } \\
\text { site, natural logs }\end{array}$ & $\begin{array}{c}0.021 \\
(0.080)\end{array}$ & $\begin{array}{c}0.012 \\
(0.067)\end{array}$ & $\begin{array}{c}0.002 \\
(0.078)\end{array}$ & $\begin{array}{c}0.011 \\
(0.076)\end{array}$ & $\begin{array}{c}0.016 \\
(0.081)\end{array}$ & $\begin{array}{l}-0.031 \\
(0.075)\end{array}$ & $\begin{array}{l}-0.139 \\
(0.106)\end{array}$ & $\begin{array}{l}-0.014 \\
(0.093)\end{array}$ & $\begin{array}{l}-2.479 \\
(1.681)\end{array}$ & $\begin{array}{c}0.026 \\
(0.087)\end{array}$ & $\begin{array}{c}0.021 \\
(0.074)\end{array}$ & $\begin{array}{c}0.021 \\
(0.086)\end{array}$ & $\begin{array}{c}0.021 \\
(0.080)\end{array}$ & $\begin{array}{c}0.021 \\
(0.039)\end{array}$ \\
\hline \multicolumn{15}{|c|}{ Panel C: Counties, 2000, $N=3480$} \\
\hline $\begin{array}{l}\text { Distance to portage } \\
\text { site, natural logs }\end{array}$ & $\begin{array}{l}-0.224 \\
(0.074) * * *\end{array}$ & $\begin{array}{l}-0.229 \\
(0.076)^{* * *}\end{array}$ & $\begin{array}{l}-0.188 \\
(0.088) * *\end{array}$ & $\begin{array}{l}-0.208 \\
(0.069)^{* * *}\end{array}$ & $\begin{array}{l}-0.227 \\
(0.075)^{* * *}\end{array}$ & $\begin{array}{l}-0.199 \\
(0.072)^{* * *}\end{array}$ & $\begin{array}{l}-0.123 \\
(0.142)\end{array}$ & $\begin{array}{l}-0.352 \\
(0.190) *\end{array}$ & $\begin{array}{l}-0.381 \\
(0.107)^{* * *}\end{array}$ & $\begin{array}{l}-0.230 \\
(0.074) * * *\end{array}$ & $\begin{array}{l}-0.224 \\
(0.105) * *\end{array}$ & $\begin{array}{l}-0.224 \\
(0.087) * *\end{array}$ & $\begin{array}{l}-0.224 \\
(0.068) * * *\end{array}$ & $\begin{array}{l}-0.224 \\
(0.067) * * *\end{array}$ \\
\hline $\begin{array}{l}\text { Centroid within } 7.5 \mathrm{mi} \\
\text { of portage site }\end{array}$ & $\begin{array}{l}1.778 \\
(0.322) * * *\end{array}$ & $\begin{array}{l}1.727 \\
(0.289)^{* * *}\end{array}$ & $\begin{array}{l}1.469 \\
(0.299)^{* * *}\end{array}$ & $\begin{array}{l}1.767 \\
(0.303) * * *\end{array}$ & $\begin{array}{l}1.778 \\
(0.322) * * *\end{array}$ & $\begin{array}{l}1.692 \\
(0.280) * * *\end{array}$ & $\begin{array}{l}1.691 \\
(0.322) * * *\end{array}$ & $\begin{array}{l}2.087 \\
(0.270) * * *\end{array}$ & $\begin{array}{l}1.163 \\
(0.230)^{* * *}\end{array}$ & $\begin{array}{l}1.845 \\
(0.359) * * *\end{array}$ & $\begin{array}{l}1.778 \\
(0.350) * * *\end{array}$ & $\begin{array}{l}1.778 \\
(0.374)^{* * *}\end{array}$ & $\begin{array}{l}1.778 \\
(0.329)^{* * *}\end{array}$ & $\begin{array}{l}1.778 \\
(0.326) * * *\end{array}$ \\
\hline $\begin{array}{l}\text { Any part within } 2 \mathrm{mi} \text { of } \\
\text { portage site }\end{array}$ & $\begin{array}{l}0.678 \\
(0.128)^{* * *}\end{array}$ & $\begin{array}{l}0.670 \\
(0.122)^{* * * *}\end{array}$ & $\begin{array}{l}0.445 \\
(0.170)^{* *}\end{array}$ & $\begin{array}{l}0.693 \\
(0.130)^{* * *}\end{array}$ & $\begin{array}{l}0.677 \\
(0.128)^{* * *}\end{array}$ & $\begin{array}{l}0.672 \\
(0.126)^{* * *}\end{array}$ & $\begin{array}{l}0.474 \\
(0.139)^{* * *}\end{array}$ & $\begin{array}{l}0.668 \\
(0.180)^{* * *}\end{array}$ & $\begin{array}{l}0.548 \\
(0.137)^{* * *}\end{array}$ & $\begin{array}{l}0.682 \\
(0.138)^{* * *}\end{array}$ & $\begin{array}{l}0.678 \\
(0.204)^{* * *}\end{array}$ & $\begin{array}{l}0.678 \\
(0.264)^{* *}\end{array}$ & $\begin{array}{l}0.678 \\
(0.116)^{* * *}\end{array}$ & $\begin{array}{l}0.678 \\
(0.214) * * *\end{array}$ \\
\hline $\begin{array}{l}\text { Both of previous two } \\
\text { conditions }\end{array}$ & $\begin{array}{l}1.593 \\
(0.261)^{* * * *}\end{array}$ & $\begin{array}{l}1.544 \\
(0.245) * * *\end{array}$ & $\begin{array}{l}1.239 \\
(0.233) * * *\end{array}$ & $\begin{array}{l}1.593 \\
(0.254)^{* * *}\end{array}$ & $\begin{array}{l}1.593 \\
(0.261)^{* * *}\end{array}$ & $\begin{array}{l}1.524 \\
(0.239)^{* * *}\end{array}$ & $\begin{array}{l}1.468 \\
(0.263) * * *\end{array}$ & $\begin{array}{l}1.870 \\
(0.216) * * *\end{array}$ & $\begin{array}{l}1.046 \\
(0.241)^{* * *}\end{array}$ & $\begin{array}{l}1.627 \\
(0.276) * * *\end{array}$ & $\begin{array}{l}1.593 \\
(0.320) * * *\end{array}$ & $\begin{array}{l}1.593 \\
(0.328)^{* * *}\end{array}$ & $\begin{array}{l}1.593 \\
(0.262)^{* * *}\end{array}$ & $\begin{array}{l}1.593 \\
(0.287)^{* * *}\end{array}$ \\
\hline $\begin{array}{l}\text { Distance to placebo } \\
\text { site, natural logs }\end{array}$ & $\begin{array}{c}0.053 \\
(0.078)\end{array}$ & $\begin{array}{c}0.051 \\
(0.077)\end{array}$ & $\begin{array}{c}0.005 \\
(0.075)\end{array}$ & $\begin{array}{c}0.085 \\
(0.066)\end{array}$ & $\begin{array}{c}0.056 \\
(0.077)\end{array}$ & $\begin{array}{l}-0.035 \\
(0.076)\end{array}$ & $\begin{array}{c}0.136 \\
(0.105)\end{array}$ & $\begin{array}{c}0.224 \\
(0.109) *\end{array}$ & $\begin{array}{l}-4.755 \\
(3.707)\end{array}$ & $\begin{array}{c}0.043 \\
(0.073)\end{array}$ & $\begin{array}{c}0.053 \\
(0.100)\end{array}$ & $\begin{array}{c}0.053 \\
(0.088)\end{array}$ & $\begin{array}{c}0.053 \\
(0.080)\end{array}$ & $\begin{array}{c}0.053 \\
(0.058)\end{array}$ \\
\hline
\end{tabular}

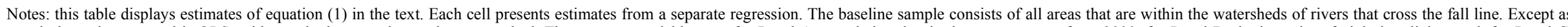

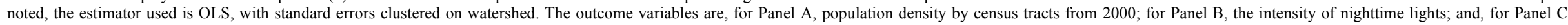

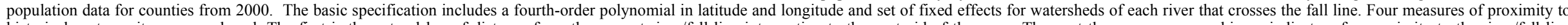

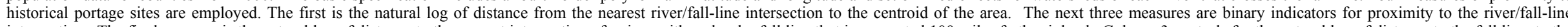

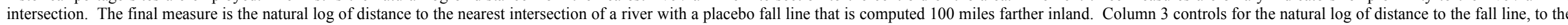

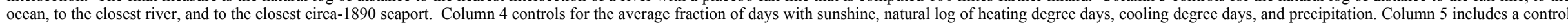

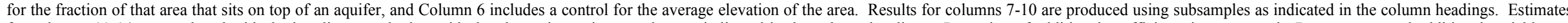

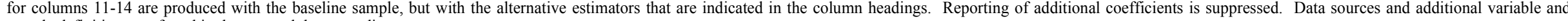
sample definitions are found in the text and the appendices. 
Table 2: Watershed Upstream from Historical Portage Site and Contemporary Population Density

\begin{tabular}{|c|c|c|c|c|c|c|c|c|c|c|c|c|c|c|}
\hline \multirow[b]{3}{*}{ Specifications: } & (1) & (2) & (3) & (4) & (5) & (6) & (7) & (8) & (9) & (10) & (11) & (12) & (13) & (14) \\
\hline & \multicolumn{2}{|c|}{ Basic } & \multicolumn{2}{|c|}{ Other Spatial Controls } & \multicolumn{3}{|c|}{ Compare with Water Power } & \multicolumn{3}{|c|}{ Alternative Samples } & \multicolumn{4}{|c|}{ Alternative Estimators } \\
\hline & & & $\begin{array}{l}\text { State } \\
\text { fixed } \\
\text { effects }\end{array}$ & $\begin{array}{l}\text { Distance } \\
\text { from } \\
\text { various } \\
\text { features }\end{array}$ & & & & $\begin{array}{l}\text { Within } \\
5 \mathrm{~km} \text { of } \\
\text { fall line }\end{array}$ & $\begin{array}{l}\text { Portage } \\
\text { sites only }\end{array}$ & $\begin{array}{c}\text { Portage } \\
\text { or water- } \\
\text { power } \\
\text { sites }\end{array}$ & $\begin{array}{l}\text { Cluster } \\
\text { on State }\end{array}$ & $\begin{array}{l}\text { Cluster } \\
\text { on } 60 \mathrm{~km} \\
\text { grid cells }\end{array}$ & $\begin{array}{l}\text { Boot- } \\
\text { strap on } \\
\text { river }\end{array}$ & $\begin{array}{l}\text { Conley's } \\
\text { estimator } \\
100 \text {-mile } \\
\text { cutoff }\end{array}$ \\
\hline Explanatory variables: & & \multicolumn{13}{|c|}{ Panel A: Census Tracts, 2000, $N=21452$} \\
\hline $\begin{array}{l}\text { Portage site times } \\
\text { upstream watershed }\end{array}$ & $\begin{array}{c}0.324 \\
(0.160) * *\end{array}$ & $\begin{array}{l}0.141 \\
(0.020) * * *\end{array}$ & $\begin{array}{c}0.373 \\
(0.150) * *\end{array}$ & $\begin{array}{l}0.355 \\
(0.112)^{* * *}\end{array}$ & $\begin{array}{l}0.142 \\
(0.019) * * *\end{array}$ & & $\begin{array}{c}0.326 \\
(0.157) * *\end{array}$ & $\begin{array}{l}0.386 \\
(0.149)^{* * *}\end{array}$ & $\begin{array}{c}0.166 \\
(0.108)\end{array}$ & $\begin{array}{l}0.186 \\
(0.101) *\end{array}$ & $\begin{array}{l}0.324 \\
(0.177) *\end{array}$ & $\begin{array}{c}0.324 \\
(0.180) *\end{array}$ & $\begin{array}{c}0.324 \\
(0.192) *\end{array}$ & $\begin{array}{l}0.324 \\
(0.111) * * *\end{array}$ \\
\hline $\begin{array}{l}\text { Binary indicator for } \\
\text { portage site }\end{array}$ & $\begin{array}{l}-1.602 \\
(1.369)\end{array}$ & & $\begin{array}{l}-2.076 \\
(1.277)\end{array}$ & $\begin{array}{l}-1.757 \\
(0.943) *\end{array}$ & & $\begin{array}{l}1.195 \\
(0.169) * * *\end{array}$ & $\begin{array}{l}-1.611 \\
(1.346)\end{array}$ & $\begin{array}{l}-2.154 \\
(1.300)\end{array}$ & & $\begin{array}{l}-0.369 \\
(0.922)\end{array}$ & $\begin{array}{l}-1.602 \\
(1.514)\end{array}$ & $\begin{array}{l}-1.602 \\
(1.619)\end{array}$ & $\begin{array}{l}-1.602 \\
(1.671)\end{array}$ & $\begin{array}{l}-1.602 \\
(0.907)\end{array}$ \\
\hline $\begin{array}{l}\text { Water-power site } \\
\text { times height of falls }\end{array}$ & & & & & $\begin{array}{l}-0.358 \\
(0.029) * * *\end{array}$ & & $\begin{array}{l}-0.367 \\
(0.068) * * *\end{array}$ & & & $\begin{array}{l}-0.460 \\
(0.050) * * *\end{array}$ & & & & \\
\hline $\begin{array}{l}\text { Binary indicator for } \\
\text { water-power site }\end{array}$ & & & & & & $\begin{array}{l}-0.031 \\
(0.319)\end{array}$ & $\begin{array}{l}-0.034 \\
(0.332)\end{array}$ & & & & & & & \\
\hline \multirow[t]{2}{*}{$\begin{array}{l}\text { Watershed area times } \\
\text { falls height times site }\end{array}$} & & & & & & & $\begin{array}{c}0.003 \\
(0.013)\end{array}$ & & & & & & & \\
\hline & & \multicolumn{13}{|c|}{ Panel B: Nighttime Lights, $1996-97, N=65000$} \\
\hline $\begin{array}{l}\text { Portage site times } \\
\text { upstream watershed }\end{array}$ & $\begin{array}{l}0.356 \\
(0.099)^{* * *}\end{array}$ & $\begin{array}{l}0.097 \\
(0.015) * * *\end{array}$ & $\begin{array}{l}0.312 \\
(0.091)^{* * *}\end{array}$ & $\begin{array}{l}0.328 \\
(0.094) * * *\end{array}$ & $\begin{array}{l}0.087 \\
(0.014) * * *\end{array}$ & & $\begin{array}{l}0.336 \\
(0.094) * * *\end{array}$ & $\begin{array}{l}0.313 \\
(0.073) * * *\end{array}$ & $\begin{array}{l}0.230 \\
(0.077) * * *\end{array}$ & $\begin{array}{l}0.204 \\
(0.090) * *\end{array}$ & $\begin{array}{l}0.356 \\
(0.085) * * *\end{array}$ & $\begin{array}{l}0.356 \\
(0.089)^{* * *}\end{array}$ & $\begin{array}{l}0.356 \\
(0.109) * * *\end{array}$ & $\begin{array}{l}0.356 \\
(0.088) * * *\end{array}$ \\
\hline $\begin{array}{l}\text { Binary indicator for } \\
\text { portage site }\end{array}$ & $\begin{array}{l}-2.235 \\
(0.807) * * *\end{array}$ & & $\begin{array}{l}-1.919 \\
(0.750) * *\end{array}$ & $\begin{array}{l}-2.275 \\
(0.765) * * *\end{array}$ & & $\begin{array}{l}0.699 \\
(0.122) * * *\end{array}$ & $\begin{array}{l}-2.134 \\
(0.770) * * *\end{array}$ & $\begin{array}{l}-2.008 \\
(0.605) * * *\end{array}$ & & $\begin{array}{l}-1.309 \\
(0.805)\end{array}$ & $\begin{array}{l}-2.235 \\
(0.748) * * *\end{array}$ & $\begin{array}{l}-2.235 \\
(0.747) * * *\end{array}$ & $\begin{array}{l}-2.235 \\
(0.909) * *\end{array}$ & $\begin{array}{l}-2.235 \\
(0.794) * * *\end{array}$ \\
\hline $\begin{array}{l}\text { Water-power site } \\
\text { times height of falls }\end{array}$ & & & & & $\begin{array}{l}0.140 \\
(0.044) * * *\end{array}$ & & $\begin{array}{l}-0.083 \\
(0.116)\end{array}$ & & & $\begin{array}{l}0.157 \\
(0.048) * * *\end{array}$ & & & & \\
\hline $\begin{array}{l}\text { Binary indicator for } \\
\text { water-power site }\end{array}$ & & & & & & $\begin{array}{l}0.598 \\
(0.173)^{* * *}\end{array}$ & $\begin{array}{c}0.888 \\
(0.442) * *\end{array}$ & & & & & & & \\
\hline \multirow[t]{2}{*}{$\begin{array}{l}\text { Watershed area times } \\
\text { falls height times site }\end{array}$} & & & & & & & $\begin{array}{l}-0.001 \\
(0.008)\end{array}$ & & & & & & & \\
\hline & & \multicolumn{13}{|c|}{ Panel C: Counties, 2000, $N=3480$} \\
\hline $\begin{array}{l}\text { Portage site times } \\
\text { upstream watershed }\end{array}$ & $\begin{array}{l}0.450 \\
(0.184) * *\end{array}$ & $\begin{array}{l}0.195 \\
(0.029) * * *\end{array}$ & $\begin{array}{l}0.399 \\
(0.177) * *\end{array}$ & $\begin{array}{c}0.439 \\
(0.169) * *\end{array}$ & $\begin{array}{l}0.192 \\
(0.029) * * *\end{array}$ & & $\begin{array}{c}0.478 \\
(0.189) * *\end{array}$ & $\begin{array}{c}0.371 \\
(0.163)^{* *}\end{array}$ & $\begin{array}{l}0.490 \\
(0.129)^{* * *}\end{array}$ & $\begin{array}{c}0.444 \\
(0.176) * *\end{array}$ & $\begin{array}{l}0.450 \\
(0.145)^{* * *}\end{array}$ & $\begin{array}{l}0.450 \\
(0.134)^{* * *}\end{array}$ & $\begin{array}{l}0.450 \\
(0.171) * * *\end{array}$ & $\begin{array}{l}0.450 \\
(0.196) * * *\end{array}$ \\
\hline $\begin{array}{l}\text { Binary indicator for } \\
\text { portage site }\end{array}$ & $\begin{array}{l}-2.182 \\
(1.519)\end{array}$ & & $\begin{array}{l}-1.784 \\
(1.463)\end{array}$ & $\begin{array}{l}-2.444 \\
(1.385) *\end{array}$ & & $\begin{array}{l}1.569 \\
(0.264) * * *\end{array}$ & $\begin{array}{l}-2.317 \\
(1.562)\end{array}$ & $\begin{array}{l}-1.650 \\
(1.392)\end{array}$ & & $\begin{array}{l}-2.388 \\
(1.539)\end{array}$ & $\begin{array}{l}-2.182 \\
(1.268) *\end{array}$ & $\begin{array}{l}-2.182 \\
(1.155) *\end{array}$ & $\begin{array}{l}-2.182 \\
(1.447)\end{array}$ & $\begin{array}{l}-2.182 \\
(1.661)\end{array}$ \\
\hline $\begin{array}{l}\text { Water-power site } \\
\text { times height of falls }\end{array}$ & & & & & $\begin{array}{c}0.051 \\
(0.031)\end{array}$ & & $\begin{array}{c}0.001 \\
(0.102)\end{array}$ & & & $\begin{array}{c}0.108 \\
(0.119)\end{array}$ & & & & \\
\hline $\begin{array}{l}\text { Binary indicator for } \\
\text { water-power site }\end{array}$ & & & & & & $\begin{array}{c}0.234 \\
(0.125) *\end{array}$ & $\begin{array}{c}0.284 \\
(0.423)\end{array}$ & & & & & & & \\
\hline $\begin{array}{l}\text { Watershed area times } \\
\text { falls height times site }\end{array}$ & & & & & & & $\begin{array}{l}-0.028 \\
(0.012) * *\end{array}$ & & & & & & & \\
\hline
\end{tabular}

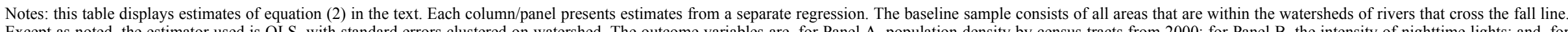

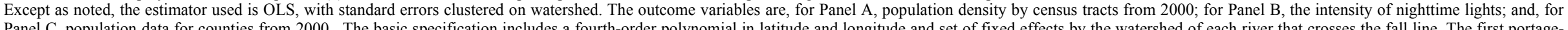

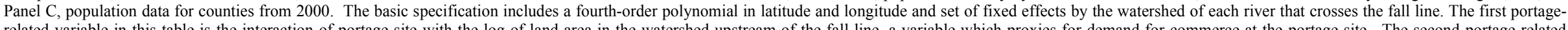

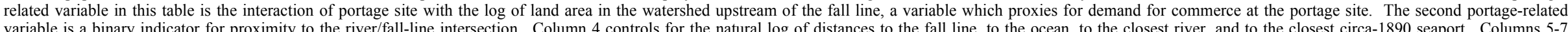

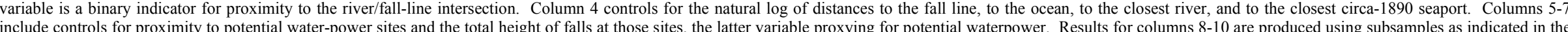

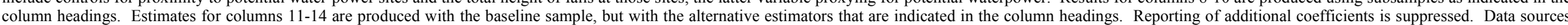
and additional variable and sample definitions are found in the text and the appendices. 


\begin{tabular}{|c|c|c|c|c|c|c|c|c|c|}
\hline & (1) & (2) & (3) & (4) & (5) & (6) & (7) & (8) & (9) \\
\hline Additional variable: & Baseline & $\begin{array}{l}1850 \\
\text { density }\end{array}$ & $\begin{array}{l}1900 \\
\text { density }\end{array}$ & $\begin{array}{l}1950 \\
\text { density }\end{array}$ & $\begin{array}{c}\text { Water } \\
\text { power in } \\
\text { use } 1890 \\
\text { dummy }\end{array}$ & $\begin{array}{l}\text { Water } \\
\text { power in } \\
\text { use } 1890 \\
\text { logs }\end{array}$ & $\begin{array}{c}\text { Railroad, } \\
1850, \\
\text { dummy }\end{array}$ & $\begin{array}{c}\text { Railroad } \\
\text { network } \\
\text { length, } \\
1850\end{array}$ & $\begin{array}{c}\text { Distance } \\
\text { to RR } \\
\text { Hub, } \\
1850\end{array}$ \\
\hline Explanatory variables: & \multicolumn{9}{|c|}{ Panel A: Binary indicator for portage site } \\
\hline $\begin{array}{l}\text { Binary indicator for } \\
\text { portage site }\end{array}$ & $\begin{array}{l}1.593 \\
(0.261) * * *\end{array}$ & $\begin{array}{l}1.029 \\
(0.240) * * *\end{array}$ & $\begin{array}{c}0.503 \\
(0.226) * *\end{array}$ & $\begin{array}{c}0.149 \\
(0.172)\end{array}$ & $\begin{array}{l}1.519 \\
(0.255) * * *\end{array}$ & $\begin{array}{l}1.521 \\
(0.256) * * *\end{array}$ & $\begin{array}{l}1.426 \\
(0.241) * * *\end{array}$ & $\begin{array}{l}1.409 \\
(0.236) * * *\end{array}$ & $\begin{array}{l}1.353 \\
(0.250) * * *\end{array}$ \\
\hline \multirow[t]{2}{*}{ Additional variable } & & $\begin{array}{l}0.917 \\
(0.089) * * *\end{array}$ & $\begin{array}{l}1.121 \\
(0.068) * * *\end{array}$ & $\begin{array}{l}0.918 \\
(0.030)^{* * *}\end{array}$ & $\begin{array}{l}0.413 \\
(0.156) * *\end{array}$ & $\begin{array}{l}0.045 \\
(0.017) * *\end{array}$ & $\begin{array}{l}0.642 \\
(0.122)^{* * *}\end{array}$ & $\begin{array}{l}0.105 \\
(0.020) * * *\end{array}$ & $\begin{array}{l}-0.585 \\
(0.096) * * *\end{array}$ \\
\hline & \multicolumn{9}{|c|}{ Panel B: Portage site times upstream watershed } \\
\hline $\begin{array}{l}\text { Portage site times } \\
\text { upstream watershed }\end{array}$ & $\begin{array}{l}0.195 \\
(0.029)^{* * *}\end{array}$ & $\begin{array}{c}0.126 \\
(0.028) * * *\end{array}$ & $\begin{array}{c}0.064 \\
(0.028)^{* *}\end{array}$ & $\begin{array}{c}0.015 \\
(0.021)\end{array}$ & $\begin{array}{l}0.186 \\
(0.029)^{* * *}\end{array}$ & $\begin{array}{l}0.186 \\
(0.029)^{* * *}\end{array}$ & $\begin{array}{l}0.175 \\
(0.027)^{* * *}\end{array}$ & $\begin{array}{c}0.173 \\
(0.027)^{* * *}\end{array}$ & $\begin{array}{c}0.167 \\
(0.028) * * *\end{array}$ \\
\hline \multirow[t]{2}{*}{ Additional variable } & & $\begin{array}{l}0.914 \\
(0.088) * * *\end{array}$ & $\begin{array}{l}1.119 \\
(0.068) * * *\end{array}$ & $\begin{array}{l}0.919 \\
(0.030) * * *\end{array}$ & $\begin{array}{l}0.402 \\
(0.155) * *\end{array}$ & $\begin{array}{l}0.044 \\
(0.017)^{* * *}\end{array}$ & $\begin{array}{l}0.640 \\
(0.122) * * *\end{array}$ & $\begin{array}{l}0.105 \\
(0.020) * * *\end{array}$ & $\begin{array}{l}-0.584 \\
(0.096) * * *\end{array}$ \\
\hline & \multicolumn{9}{|c|}{ Panel C: Portage-site dummy and upstream-watershed interaction } \\
\hline $\begin{array}{l}\text { Portage site times } \\
\text { upstream watershed }\end{array}$ & $\begin{array}{l}0.450 \\
(0.184) * *\end{array}$ & $\begin{array}{c}0.287 \\
(0.181)\end{array}$ & $\begin{array}{c}0.253 \\
(0.199)\end{array}$ & $\begin{array}{l}-0.122 \\
(0.119)\end{array}$ & $\begin{array}{c}0.421 \\
(0.179) * *\end{array}$ & $\begin{array}{l}0.420 \\
(0.180) * *\end{array}$ & $\begin{array}{l}0.417 \\
(0.173) * *\end{array}$ & $\begin{array}{c}0.414 \\
(0.169) * *\end{array}$ & $\begin{array}{c}0.453 \\
(0.173) * *\end{array}$ \\
\hline $\begin{array}{l}\text { Binary indicator for } \\
\text { portage site }\end{array}$ & $\begin{array}{l}-2.182 \\
(1.519)\end{array}$ & $\begin{array}{l}-1.371 \\
(1.520)\end{array}$ & $\begin{array}{l}-1.613 \\
(1.663)\end{array}$ & $\begin{array}{c}1.168 \\
(0.982)\end{array}$ & $\begin{array}{l}-2.011 \\
(1.486)\end{array}$ & $\begin{array}{l}-1.999 \\
(1.491)\end{array}$ & $\begin{array}{l}-2.073 \\
(1.421)\end{array}$ & $\begin{array}{l}-2.062 \\
(1.392)\end{array}$ & $\begin{array}{l}-2.450 \\
(1.421) *\end{array}$ \\
\hline \multirow[t]{2}{*}{ Additional variable } & & $\begin{array}{l}0.912 \\
(0.088) * * *\end{array}$ & $\begin{array}{l}1.119 \\
(0.068)^{* * *}\end{array}$ & $\begin{array}{l}0.919 \\
(0.030)^{* * *}\end{array}$ & $\begin{array}{c}0.395 \\
(0.155) * *\end{array}$ & $\begin{array}{c}0.043 \\
(0.017) * *\end{array}$ & $\begin{array}{l}0.639 \\
(0.122) * * *\end{array}$ & $\begin{array}{l}0.105 \\
(0.020)^{* * *}\end{array}$ & $\begin{array}{l}-0.585 \\
(0.096) * * *\end{array}$ \\
\hline & \multicolumn{9}{|c|}{ Panel D: Replicate Panels A and B for counties within 150 miles of the Fall Line } \\
\hline $\begin{array}{l}\text { Portage site times } \\
\text { upstream watershed }\end{array}$ & $\begin{array}{l}0.153 \\
(0.024) * * *\end{array}$ & $\begin{array}{l}0.124 \\
(0.023) * * *\end{array}$ & $\begin{array}{l}0.067 \\
(0.020) * * *\end{array}$ & $\begin{array}{c}0.008 \\
(0.020)\end{array}$ & $\begin{array}{l}0.144 \\
(0.024) * * *\end{array}$ & $\begin{array}{l}0.145 \\
(0.024) * * *\end{array}$ & $\begin{array}{l}0.149 \\
(0.025) * * *\end{array}$ & $\begin{array}{l}0.149 \\
(0.025)^{* * *}\end{array}$ & $\begin{array}{c}0.140 \\
(0.024)^{* * *}\end{array}$ \\
\hline \multirow[t]{2}{*}{$\begin{array}{l}\text { Binary indicator for } \\
\text { portage site }\end{array}$} & $\begin{array}{l}1.265 \\
(0.218)^{* * *}\end{array}$ & $\begin{array}{l}1.013 \\
(0.203) * * *\end{array}$ & $\begin{array}{c}0.573 \\
(0.173) * * *\end{array}$ & $\begin{array}{c}0.097 \\
(0.166)\end{array}$ & $\begin{array}{l}1.196 \\
(0.211)^{* * *}\end{array}$ & $\begin{array}{l}1.203 \\
(0.212)^{* * *}\end{array}$ & $\begin{array}{l}1.235 \\
(0.219)^{* * *}\end{array}$ & $\begin{array}{l}1.231 \\
(0.219) * * *\end{array}$ & $\begin{array}{l}1.156 \\
(0.212) * * *\end{array}$ \\
\hline & \multicolumn{9}{|c|}{ Panel E: Replicate Panels A and B for the South only } \\
\hline $\begin{array}{l}\text { Portage site times } \\
\text { upstream watershed }\end{array}$ & $\begin{array}{c}0.181 \\
(0.032) * * *\end{array}$ & $\begin{array}{l}0.147 \\
(0.029) * * *\end{array}$ & $\begin{array}{c}0.085 \\
(0.026) * * *\end{array}$ & $\begin{array}{c}0.024 \\
(0.016)\end{array}$ & $\begin{array}{l}0.172 \\
(0.031) * * *\end{array}$ & $\begin{array}{l}0.172 \\
(0.031) * * *\end{array}$ & $\begin{array}{l}0.163 \\
(0.030) * * *\end{array}$ & $\begin{array}{c}0.163 \\
(0.029)^{* * *}\end{array}$ & $\begin{array}{c}0.164 \\
(0.029) * * *\end{array}$ \\
\hline $\begin{array}{l}\text { Binary indicator for } \\
\text { portage site }\end{array}$ & $\begin{array}{l}1.482 \\
(0.281)^{* * *}\end{array}$ & $\begin{array}{l}1.216 \\
(0.251)^{* * *}\end{array}$ & $\begin{array}{l}0.672 \\
(0.222) * * *\end{array}$ & $\begin{array}{c}0.222 \\
(0.142)\end{array}$ & $\begin{array}{l}1.402 \\
(0.273)^{* * *}\end{array}$ & $\begin{array}{l}1.406 \\
(0.273)^{* * *}\end{array}$ & $\begin{array}{l}1.332 \\
(0.259)^{* * *}\end{array}$ & $\begin{array}{l}1.328 \\
(0.255)^{* * *}\end{array}$ & $\begin{array}{c}1.335 \\
(0.258) * * *\end{array}$ \\
\hline
\end{tabular}

Notes: this table displays estimates of equations (1) and (2) in the text. The outcome variable is population density, measured in natural logarithms. Each column/panel presents estimates from a separate regression. The sample consists of all US counties, from the year 2000, that are within the watersheds of rivers that cross the fall line, except for Panels D and E, which are further restricted to counties either within 150km of the fall line or within the South, respectively. The estimator used is OLS, with standard errors clustered on watershed. The basic specification includes a polynomial in latitude and longitude and set of fixed effects by the watershed of each river that crosses the fall line. Two portage-related variables are used in this table. The first is a binary indicator for proximity to the river/fall-line intersection. The second is the interection of portage site with the log of land area in the watershed upstream of the indicator for proxl the a the fall line, a rage-site incator, Panel B contain results using the watershed interaction, and Panel $C$ reports a specification in which both variables are included. Panels $D$ and $E$ replicate the results for Panels $A$ and $B$ in the indicated subsamples. Further, for Panels D and E, each cell represents the result from a separate regression, and the reporting or the coefficient on the additional variable is suppressed. The baseline specification is used for column 1. Each subsequent column adds one more variable, as indicated in the column heading. The coefficient estimate on this variable is reported in the row marked "additional variable". Columns 2-4 report estimates with controls for lagged population density, which were matched onto the year-2000 county boundaries using a spatial join in ArcGIS. Columns 5-6 report specifications in which the water power in use in 1890 is included as a control, either by the extensive or intensive margins. Columns 7-9 include measures of railroads in that county in 1850. (To accommodate zeros and the use of logs in columns 6 and 8, we add 1 to the variable before taking logs.) Reporting of additional coefficients is suppressed. Data sources and additional variable and sample definitions are found in the text and the appendices. 
Table 4: Housing Prices, Portage, and Population Density

(1) (2)

(3)

(4)

(5)

(6)

(7)

Additional variable:

Median Rent, 1990

Median price, 1990

Median price, 1940

Travel time, 1990

Explanatory variables:

Panel A: Binary indicator for portage site

Binary indicator for

$\begin{array}{llll}0.142 & -0.034 & 0.146 & -0.052\end{array}$

$(0.036) * * * \quad(0.030)$

$(0.069) * *$

(0.040)

0.296

0.028

$-0.044$

$-0.032$

portage site

No

Yes

No

Yes

$(0.145) * *$

$(0.100)$

$(0.036)$

$(0.038)$

Polynomial in $\log$

population density?

Panel B: Portage site times upstream watershed

\begin{tabular}{|c|c|c|c|c|c|c|c|c|}
\hline $\begin{array}{l}\text { Portage site times } \\
\text { upstream watershed }\end{array}$ & $\begin{array}{l}0.018 \\
(0.004) * * *\end{array}$ & $\begin{array}{l}-0.004 \\
(0.003)\end{array}$ & $\begin{array}{l}0.020 \\
(0.008) * *\end{array}$ & $\begin{array}{l}-0.005 \\
(0.004)\end{array}$ & $\begin{array}{l}0.039 \\
(0.017) * *\end{array}$ & $\begin{array}{c}0.005 \\
(0.012)\end{array}$ & $\begin{array}{l}-0.005 \\
(0.004)\end{array}$ & $\begin{array}{l}-0.004 \\
(0.004)\end{array}$ \\
\hline $\begin{array}{l}\text { Polynomial in log } \\
\text { population density? }\end{array}$ & No & Yes & No & Yes & No & Yes & No & Yes \\
\hline
\end{tabular}

Notes: this table displays estimates of equations (1) and (2) in the text. The outcome variable is the median housing rent, housing price, and travel time, all measured in natural logarithms. Each column/panel presents estimates from a separate regression. The sample consists of all US counties, from indicated year, that are within the watersheds of rivers that cross the fall line. The estimator used is OLS, with standard errors clustered on watershed. The basic specification includes a polynomial in latitude and longitude and set of fixed effects by the watershed of each river that crosses the fall line. Two portage-related variables are used in this table. The first is a binary indicator for proximity to the river/fall-line intersection. The second is the interaction of portage site with the log of land area in the watershed upstream of the fall line, a variable that proxies for demand for commerce at the portage site. Panel A reports results using the binary portage-site indicator; Panel B contains results using the watershed interaction. The baseline specification is used for the odd-numbered columns. Specifications reported in the even-numbered columns also include a sixth-order polynomial in population density. Reporting of additional coefficients is suppressed. Data sources and additional variable and sample definitions are found in the text and the appendices. 
Table 5: The Predictive Power of Historical Portage, 1790-1870 versus 1950-2000
(2)
(3)

(1)

(4)

(5)

(6)

(7)

(8)

(9)

(10)

Sample of counties within 150 miles of the Fall Line

Sample modification or alternate coding of portage

$\begin{array}{cc} & \text { Samp } \\ \text { Baseline } & \text { Use } \\ \text { double } \\ \text { radius to } \\ \text { define } \\ \text { sites }\end{array}$

$\begin{array}{ccccc}\text { Use } & \text { Use } & & & 1790- \\ \text { distance } & \text { distance } & \text { Verified } & 1850-80 & 1860 \mathrm{vs} \\ \text { to border } & \text { to } & \text { falls only } & \text { vs } 1970- & 1930- \\ \text { only } & \text { centroid } & & 2000 & 2000\end{array}$

\begin{tabular}{cccc}
\multicolumn{4}{c}{ Other samples } \\
\hline $\begin{array}{c}\text { Atlantic } \\
\text { rivers } \\
\text { only }\end{array}$ & $\begin{array}{c}\text { Whole } \\
\text { sample }\end{array}$ & $\begin{array}{c}\text { buffer } \\
\text { around } \\
\text { Fall Line }\end{array}$ & Whole \\
& & South
\end{tabular}

Explanatory variables:

Binary indicator for portage site

$\begin{array}{lcc}0.596 & 0.408 & 0.201 \\ (0.154) * * * & (0.084) * * * & (0.088) * *\end{array}$

Panel A: Binary indicator for portage site

\section{Binary indicator for}

portage site $\mathrm{x} 20$ th century

$0.300 \quad 0.039$

$(0.191) \quad(0.148)$

0.299

$(0.119) * *$

0.811
$(0.191)^{* * *}$

$\begin{array}{lll}0.363 & 0.449 & 0.891\end{array}$

$\begin{array}{llll}0.283 & 0.526 & 0.486 & 0.200\end{array}$

$(0.164) *$

$(0.239) * *$

$(0.219) * *$

(0.234)

Panel B: Portage site times upstream watershed

\begin{tabular}{|c|c|c|c|c|c|c|c|c|c|c|c|}
\hline $\begin{array}{l}\text { Portage site x upstream } \\
\text { watershed }\end{array}$ & $\begin{array}{l}0.076 \\
(0.016) * * *\end{array}$ & $\begin{array}{l}0.040 \\
(0.012) * * *\end{array}$ & $\begin{array}{l}0.037 \\
(0.010) * * *\end{array}$ & $\begin{array}{l}0.126 \\
(0.025) * * *\end{array}$ & $\begin{array}{l}0.047 \\
(0.016) * * *\end{array}$ & $\begin{array}{l}0.059 \\
(0.022) * *\end{array}$ & $\begin{array}{l}0.111 \\
(0.033) * * *\end{array}$ & $\begin{array}{l}0.042 \\
(0.015) * *\end{array}$ & $\begin{array}{l}0.109 \\
(0.031)^{* * *}\end{array}$ & $\begin{array}{l}0.065 \\
(0.012) * * *\end{array}$ & $\begin{array}{l}0.072 \\
(0.017) * * *\end{array}$ \\
\hline $\begin{array}{l}\text { Portage site } \mathrm{x} \text { upstream } \\
\text { watershed } \mathrm{x} 20 \text { th century }\end{array}$ & $\begin{array}{c}0.037 \\
(0.023)\end{array}$ & $\begin{array}{l}0.078 \\
(0.023)^{* * *}\end{array}$ & $\begin{array}{l}0.097 \\
(0.020) * * *\end{array}$ & $\begin{array}{l}-0.008 \\
(0.026)\end{array}$ & $\begin{array}{l}0.064 \\
(0.029) * *\end{array}$ & $\begin{array}{c}0.057 \\
(0.027) * *\end{array}$ & $\begin{array}{c}0.025 \\
(0.028)\end{array}$ & $\begin{array}{l}0.087 \\
(0.030) * * *\end{array}$ & $\begin{array}{c}0.036 \\
(0.029)\end{array}$ & $\begin{array}{c}0.040 \\
(0.021) *\end{array}$ & $\begin{array}{l}0.078 \\
(0.022) * * *\end{array}$ \\
\hline
\end{tabular}

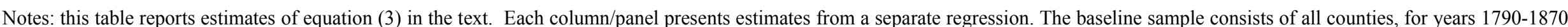

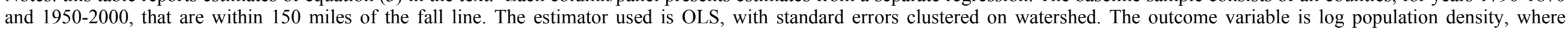

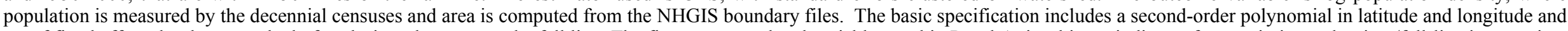

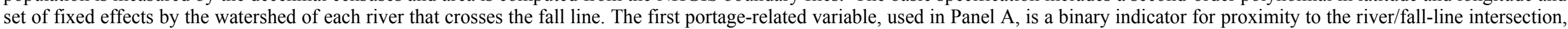

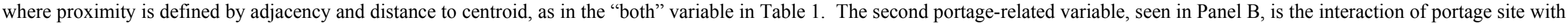

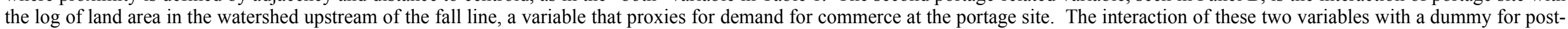

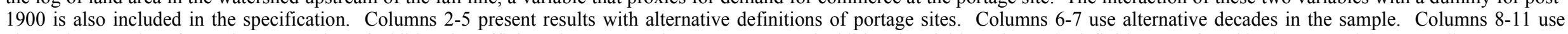

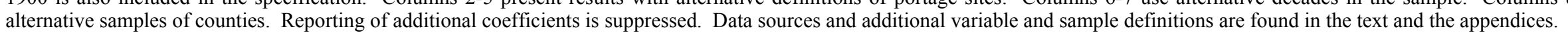




\section{A Data appendix}

\section{A.1 The fall line}

We use data on counties in fall-line river watersheds. The base data are county shapefiles, 17902000, from the National Historical Geographic Information System (NHGIS), matched to county populations (and other data) from the Haines (2004) extracts of the decennial U.S. censuses.

First, we select counties based on their location within river watersheds that intersect the fall line. The fall line itself, from Texas to New Jersey, is digitized from the map Physical Divisions of the United States. (Appendix Figure A shows the digitized fall line, in solid black, superimposed over both the rivers layer and the nighttime lights layer.) We select the 51 large rivers between the Rio Grande and the Delaware rivers, inclusive, from the North American Atlas-Hydrography map layer available on NationalAtlas.gov that intersect the fall line. Two smaller rivers, the Raritan River in New Jersey and the Appomattox River in Virginia, are added from the Streams and Waterbodies layer. Hydrologic units from the Hydrologic Units (Watersheds) layer are then aggregated to entire river watersheds and matched to each of the 53 rivers. In addition, we identify the locations of likely historical portage sites by intersecting the fall-line layer with the rivers map layer. These steps form a basic "sampling" layer, which is then used to select counties in each decennial NHGIS map layer. Counties that lay on the boundary of multiple watersheds are assigned to the watershed of the closest river, when we perform our across-watershed analyses.

Second, we intersect each decade's sampled county layer with various map layers containing geographic information. These layers include information on spatial relationships (county distances to the fall line, seaports, or the Atlantic coast, county position upstream or downstream of the fall line, county adjacency to fall-line portage sites), fixed characteristics of counties (climate, elevation, the presence of aquifers, and potential water power), and mobile factors (the locations of 19th-century railroads, state capitals). The major 19th-century seaports (Baltimore, Norfolk, Wilmington, Charleston, Savannah, Mobile, New Orleans, and Galveston) are taken from Phillips (1905). Climate data are from the Climate Atlas of the United States, which reports (categorical) thirty-year averages, over 1961-1990, for most of the climate variables. Data on the locations of aquifers and other geological features are from NationalAtlas.gov.

Potential water power is from the Reports on the Water-Power of the United States (1885), published as part of the Tenth Census. The tables beginning on pages $x x x$ and $x x x$ iii summarize by river and "locality" the total water power available and the total water power then used in 
service. We geo-code this information, and in some cases we rely on textual descriptions in the accompanying survey to identify localities. The locations of 19th-century railroads are drawn from Maps 3.1, 3.2, and 3.3 in Pred (1980), covering 1840, 1850, and 1860, respectively. We digitize these maps, and then, since the precise routes are somewhat imprecise, define a buffer of 10 miles in width around the digitized rail routes. Rail length is then determined by counties that intersect this buffer, divided by 10 .

Finally, we merge each decade's spatial data with census data from the Haines extracts. In addition to data on population, the Haines extracts also include, for some years, information on the age distribution of the housing stock. We then pool the decennial county data into a single data set.

The construction of the census 2000 tract data is identical to the procedure described above. For the nighttime lights, we first sample one out of every 100 raster-resolution pixels, creating a grid of sample points, then apply the procedure described above.

\section{A.2 The Great Lakes}

The basic data sets (NHGIS and the Haines extracts) are the same for our Great Lakes sample. We first use the Hydrologic Units (Watersheds) to define the divide between the Great Lakes and the Mississippi River watersheds. (This is the dashed black line in Figure 5.) Then, we select counties that intersect a buffer of 12.5 miles in either direction from the divide. We identify 12 portage routes based on the map "Portages Between the Great Lakes and the Mississippi" (Semple, 1903, facing p. 28) and the two rivers layers from NationalAtlas.gov described earlier. Counties are assigned to portage-route groups based on distance to the nearest portage route. The remaining procedures are identical to those described in the fall-line section.

\section{A.3 The Mississippi River basin}

We select counties within 12.5 miles in either direction of each of the three major upstream branches of the Mississippi River. Major confluences with other rivers are identified from the river layers from NationalAtlas.gov described earlier. We identify early portage sites along these rivers using early-19th-century surveys from the U.S. Army Corps of Engineers, found in the Serial Set. For example, the "Survey of the Ohio and Mississippi Rivers" (17th Congress, 2nd session, H. No. 260, January 22,1823 ) notes navigation obstacles at the falls of the Ohio and other sites along the Ohio River. The report "Improvement of Missouri River" (46th Congress, 3rd session, H. Ex. 
Doc. No. 92, February 17, 1881) and Part II of the Reports on the Water-Power of the United States, in the section called "The Mississippi River and Some of its Tributaries," (U.S. Census, 1885) note seasonal navigation obstacles along the Missouri River near Sioux City, Iowa, Council Bluffs, Iowa (across from Omaha, Nebraska), and Kansas City, Missouri. Part II of the Reports on the Water-Power of the United States also notes rapids near Keokuk, Iowa, Rock Island, Illinois, and the Falls of St. Anthony, near Minneapolis. These observations are similar to those in "Report Intended to Illustrate a Map of the Hydrographical Basin of the Upper Mississippi River" (26th Congress, 2nd session, S. Doc. 237, February 16, 1841). In addition, many of these surveys (and others not cited) include notes of minor navigation obstacles at regular intervals along all these rivers and other major U.S. waterways, which, because of their large number, we do not use in this paper. We noted several examples of present-day cities at the sites of these minor navigation obstacles. Finally, we exclude portages along smaller tributaries of the Mississippi River. 


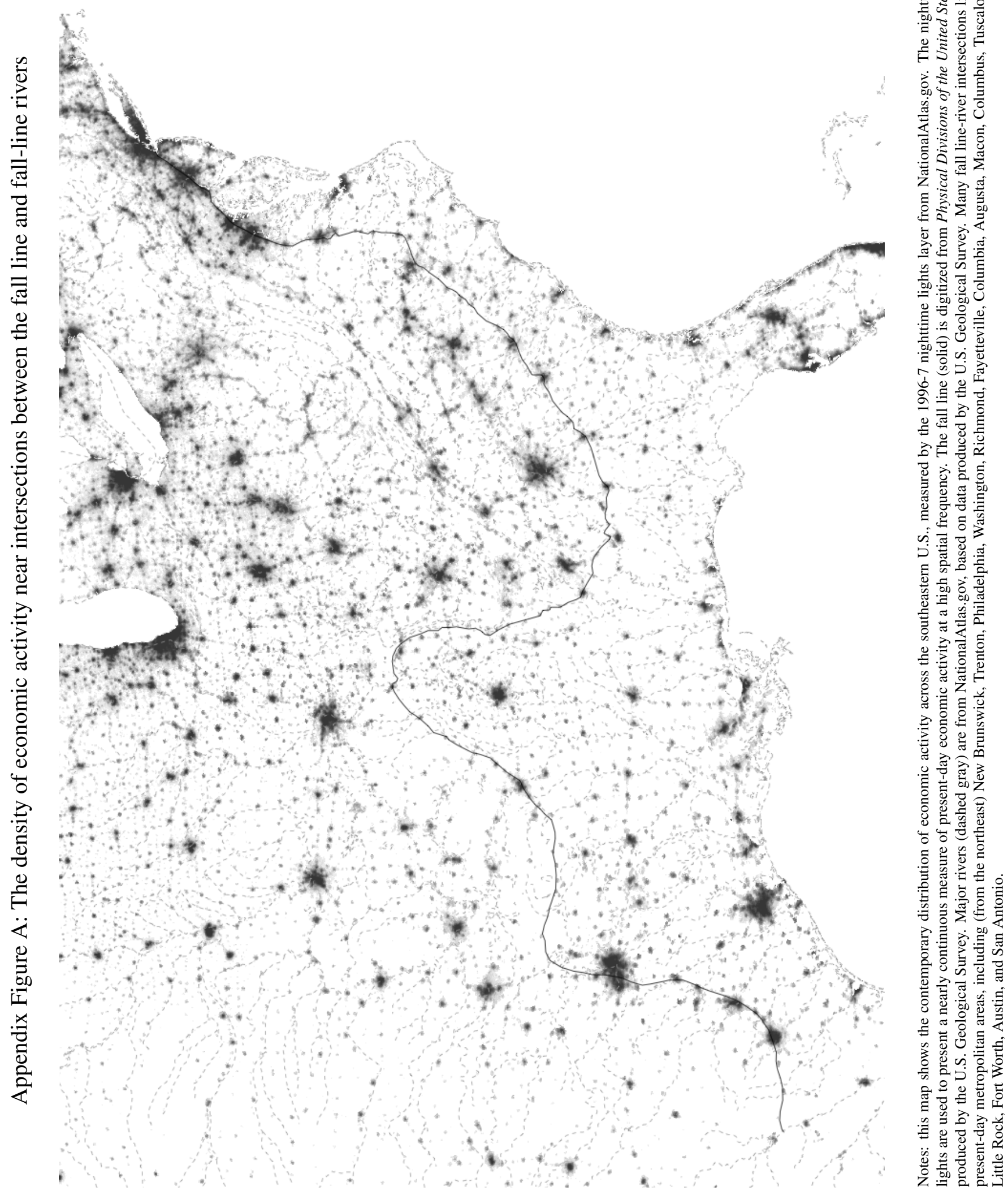

